ANITA MARZZOCO

\title{
CARACTERIZAÇĀO DO GENOMA DE UMA AMEBA DE VIDA LIVRE (Acanthamoeba castellanii)
}

Tese de Doutoramento

Universidade de São Paulo Instituto de Quimica

Departamento de Bioquímica 
Para Cristina de Paiva Mendonça Pereira Antonio Lemos Pereira José Gaspar Marzzoco 
TT A Aroviatimas..................... 3

I IT Prapentes.................... 4

TV - Introdução

L. Acanthamoeba castellanii............ 5

2. Organização do genom? em enceriotos......? ?

3. Caracterização do genoma de $\underline{A}$. castellanii 24

V . Métodos

. Crescimento de $A$. castellanii............ 30

2. Encistamento................... 32

3. Germinação (Excistamento) ............ 33

4. Isolamento de núcleos de trofozoito....... 33

5. Controle da pureza das preparações de nú-

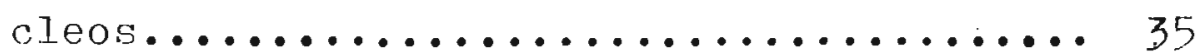

6. Dosagem de RNA, JNA e probeína em núcleos e homogenato....................... 36

7. Ensaio da atividade de RNA polimerase (E.C.2.7.7.6)................... 37

8. Puriflcação de mitocôndrias.......... 38

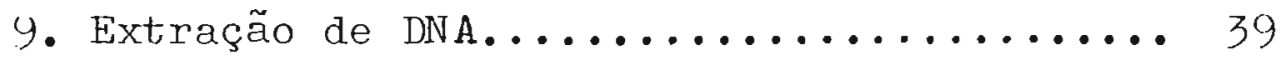

10. Centrifugação em gradientes de CsCl....... 40

11. Fragmentação de DNA................ 41.

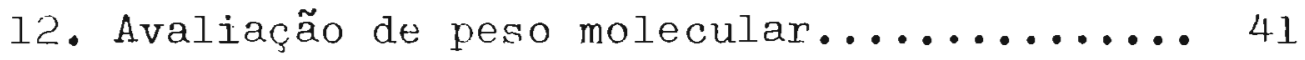

13. Renaturação de DNA................ 42

14. Curvas de desnaturação térmica (Determina-

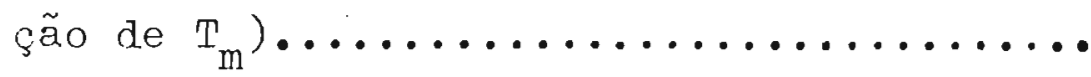

VI - Resultados

1. Curva de crescimento................. 44

2. Encistamento induzido............... 46

3. Isolamento de núcleos............... 47

4. Composição química de núcleos isolados.... 51

5. Atjvidade de RNA polimerase (E.C.2.7.7.6) em núcleos isolados............... 51 
6. Extração de DNA..................... 53

7. Centrifugação em gradientes de CsCl........ 55

8. Perfil de fusão dos componentes do DNA de

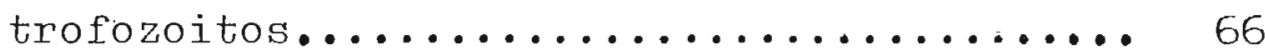

9. Renaturação de DNA.................. 70

VII • Discussão

1. Isolamento de núcleos................ 86

2. Extração de DNA.................... 87

3. Caracterização do DNA de trofozoitos

a) DNA total.................... 88

b) INA nuclear e componente maior......... 90

c) INA mitocondrial e componente menor...... 91

4. Análise das condições de renaturação....... 96

VIII. Resumo........................ 99

IX . Bibliografia.................... 100 
I. Prefácio

Este trabalho foi realizado sob a orientação segura e eficiente do Prof. Dr. Walter Colli e contou com a colaboração de várias pessoas as quajis agradeço imensamente:

Dr. Antonio Sesso - micros copia eletrônica Aparecido M. Pinto - assistência técnica

Dr. Bayardo B. Torres - leitura do manuscrito Carmen M. Pinto - assistência técnica Dra. Gláncia M. Sartielli - microscopia de fase Dra. Godeleine Fonty (Jaboratório do Dr. G. Bernadi , Ins titut de Biologie Moléculaire, Fac. des Science: de Paris) - ultracentrifugação analítica

Dra. Helena Li Chum - análise da cinética de renaturação Dra. Janne Balsamo - análise da cinética de renaturação João Luiz Musa - fotografias

Prof. Dr. José Ferreira Fernandes - adaptação ao novo regime de pós-graduação.

Dra. Lor Cury - microscopia eletrônica

Lucy Bouquet - gráficos

Dr. Luiz Longhi - microscopia eletrônica

Dra. Marilda Guedes - análise estatística dos dados Masuko Yokoyama - partj.cipação na fase inicial do traba. tho

Dr. Roberto V. Santelli - ensaio de RNA polimerase

Agradeço, ainda, ao pessoal do Bloco 10 (tér. reo e superior), especialmente aos colegas do nosso laboratiório, sempre dispostos a prestar qualquer tipo de auxílio: 


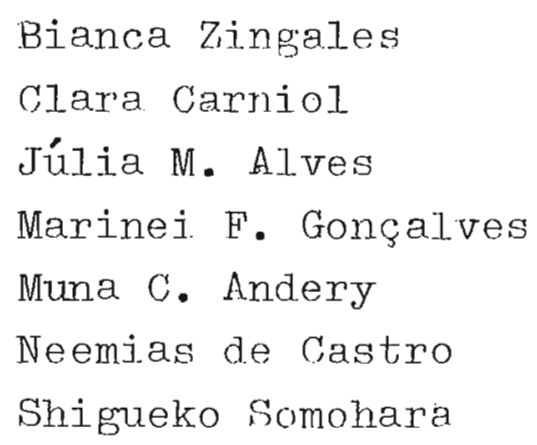

Os bacteriófagos $T_{7}$ e $f d$, foram gentilmente cedidos pelos Drs. M. Oishj e L. Day, respectivamente.0 inóculo inicial de Acanthamoeba castellanii, linhagem Neff, foi uma doação do Dr. Mo Rabjnovitch.

Este trabalho foi rem.tizado com o apojo financeiro da Fundação de Amparo à Pesquisa do Estado de São Paulo e Conselho Nacional de Pesquisas。 
II. Abreviaturas

DNA = ácido desoxirribonucleico

$G C=$ fração molar de guanina e citosina do ácido nucleic $\mathrm{AT}=$ fração molar de adenina e timina do ácido nucleico $\mathrm{T}_{\mathrm{m}}=$ temperatura de fusão do DNA

Cot = produto da concentração de DNA (moles de nucleotí dios. $1^{-1}$ ) pelo tempo (segundos) de incubação

RNA = ácido ribonucleico

rRNA = RNA ribossômico

mRNA = RNA mensageiro

rDNA = cistrons complementares a RNA ribossômico

RNase = ribonuclease

DNase = desoxirribonuclease

Tris = tris(hidroximetil) aminometano

EDTA = ácido etileno diamino tetracético

SDS = dodecil sulfato de sódio

TCA = ácido tricloroacético

$\mathrm{PCA}=$ ácido perclórico

SSC $=\mathbb{N a C l} 0,15 \mathrm{M}$; citrato de sódio $0,015 \mathrm{M}, \mathrm{pH} 7$

PPO $=2,5$-difeniloxazol

POPOP $=1$,4-bis-2-(5-feniloxazolil $)$-benzeno

$\mathrm{PVP}=$ polivinil pirrolidona 
III. Reagentes

\begin{abstract}
Além das drogas relacionadas abaixo, utiliza vam-se sempre reagentes de grau analítico.
\end{abstract}

DROGA

Proteose-peptona
Extrato de levedo
Citrato férrico
Silicone
Triton X-100
PVP

RNase

a-amilase

Ditiotreitol

Actinomicina D

Rifampicina

$\mathrm{PPO}$

POPOP

Nonidet $\mathrm{P}-40$

Hidróxido de hiamina

Tween 80

Fenol

$3_{\mathrm{H}-\mathrm{UTP}}$

CsCl ("grade A")

Pronase

2-desoxi-D-ribose

D-ribose

Albumina sérica bovina

\section{PROCEDENCTA}

Oxoid Ltd.

Difco Lab.

BDH Chem. Ltd.

c] ay-Adams, Inc.

salbiochem

Calbiochem

Sigma Chem. Comp.

Sigma Chem. Comp.

Sigma Chem. Comp.

Calbiochem

Ciba-Geigy

Calbiochem

Calbiochem

shell do Brasil S.A.

Packard Inst. Co., Inc.

BDH Chem. Lta.

Mallinckrodt Chem. Works

New England Nuclear Co.

Ialbiochem

Calbiochem

E. Merck A.G. Darmstadt

E. Merck A.G. Darmstadt

Sigma Chem. Comp. 
IV. Introdução

1. Acanthamoeba castellanii

o protozoário em estudo denomina-se Acanthamoeba castellanii (Douglas, 1930), linhagem Neff e pertence à familia das Hartmannelidae, que compreende cerca de trinta espécies provenientes do desmembramento de um grupo de amebas denominadas anteriormente "limax"(Vickerman, 1962).

A taxonomia das amebas apresenta inúmeras dificuldades e a ameba em questão, durante algum tempo, foi referida na literatura como Acanthamoeba sp. Segundo Volkonsky (1931), Adam (1964) e Page (1967), várias denominações referem-se à mesma espécie: Acanthamoeba castellanii, Acanthamoeba sp., Hartmannella rhysodes, Hartmannella culbertsoni e Hartmannella castellanii.

A. castellanii foi descoberta por Castellani (1930), como contaminante de culturas de Cryptococcus pararoseus e foi assim denominada por Douglas (1930). Pos teriormente, a ameba foi isolada de diferentes fontes:solos úmidos (Singh, 1949; Neff, 1957), água doce (Page, 1967) e culturas de tecidos (Jahnes et al., 1957; Moore e Hlinka, 1968). Demonstrou-se claramente sua patogenicidade em macacos e camundongos (Dunnebacke e Williams, 1967; Culbertson et al., 1958, 1959). Vários autores sugerem que a ameba seja o agente etiológico de várias doenças respiratórias do homem, além de meningoencefalites (Wang e Feldman, 1961; Patras e Andujar, 1966; Armstrong e Pereira, 1967; Carter, 1968; Cerva e Novak, 1968).

A divisão celular da ameba segue o curso de uma mitose típica, evidenciando-se a existência de 40 cromossomos (Volkonsky, 1931; Singh, 1952). Todavia, pode-se induzir experimentalmente a divisão celular sem mitose nuclear (amitose): o núcleo único interfásico é par- 
tilhado entre as células filhas que sobrevivem por apenas 48 horas (Band et al., 1970). A ameba é tipicamente uninucleada (Bowers e Korn, 1968), mas individuos multinucleados podem aparecer sob determinadas condições de cultura (James e Byers, 1967; Band et a1., 1970;Band e Machemer, 1963). Portanto, a divisão citoplasmática pode ser separada da divisão nuclear mitótica, fazendo com que a ameba se torne um sistema útil para o estudo de problemas de divisão celular (Band e Mohrlok,1973 a; 1973 b). Band e Mohrlok (1973 b) demonstraram que as fases de mitose e síntese de DNA, duravam, respectiva mente, 24 e 20 minutos. Resultados semelhantes foram obtidos em Physarum (Nygaard et al., 1960) e ouriço do mar (Hinegardner et al., 1964).

A. castellanii pode ser cultivada, sob condições axênicas, em vários meios líquidos (Neff et al., 1958; Band, 1959, 1962), com temperatura ótima entre 25 e $30{ }^{\circ} \mathrm{C}$. Nessas condições, o tempo de geração varia de 12 a 18 horas (Neff et al., 1964 b). O crescimente pode ser obtido em meio basal mínimo (Adam, 1959; stark, 1966). Cresce também em placas sobre culturas de bactérias ou fungos, permitindo a obtenção de clones e reconhecimento de mutantes pela morfologia da colônia (Jensen e Dubes, 1962; Upadhyay, 1968).

Culturas agitadas ou estacionárias em meio líquido apresentam curvas de crescimento onde não se verifica uma fase de "lag". As fases (exponencial e estacionária) da curva de crescimento são determinadas, principalmente, pelo nível de oxigênio dissolvido no meio (Neff et al., 1958; Band, 1959; Byers et al..1969).

Sob determinadas condições ambientais, a ameba sofre um processo de diferenciação que culmina com a formação de um novo tipo celular, o cisto. O encistamento pode ser espontâneo ou induzido. o encista mento espontâneo ocorre em culturas agitadas ou estacio nárias, em condições de alta densidade de células. A indução do encistamento é obtida através do emprego de técnicas de substituição de meios, ou seja, as amebas são transferidas de um meio nutriente rico para um meio 
salino, deficiente em fontes de carbono ou nitrogênio (Griffiths e Hughes, 1969). O encistamento também pode ser obtido em placas de agar não nutriente, contendo taurirıa e cloreto de magnésio (Raizada e Krishna Murti, 1971). Encistamento adequado requer oxigênio, presença de íons cálcio e magnésio e baixa concentração de células (Band, 1963; Griffiths e Hughes, 1968). As fases do encistamento espontâneo e induzido são praticamente as mesmas, mas a indução proporciona encistamento em massa (acima de 95\%, após 20 horas de indução) e sincronizado (Neff et al.,1964 b). o trofozoito, envolto por uma membrana plasmática(Korn e Wright, 1973), diferencia-se em uma célula viável e extremamente resistente (Adam, 1964; Neff et al.,1964 b), protegida por uma parede celular química e estruturalmente complexa. A parede, cuja composição quími ca ainda não foi totalmente elucidada, contém, como elemento predominante, celulose (Tomlinson e Jones, 1962; Neff e Benton, 1962; Page, 1967; Tomlinson,1967; Neff e Neff, 1969), além de proteina ( Neff et al., 1964 a; Bowers e Korn, 1969) e mucopolissacarídios (Krishna Murti, 1973).

O encistamento ocorre em condições onde a célula não dispõe de qualquer suprimento exogeno e os componentes da parede não estão presentes no trofozoito. Evidências citológicas (Bowers e Korn, 1969) e bioquímicas (Neff e Neff,1969;Griffiths e Hughes,1969; Weisman et al., 1970) indicam que a celulose é sinteti zada "de novo", às expensas de glicogênio que constitui o material de reserva do trofozoito (Stark, 1966). A atividade de $\quad$-glicana sintetase não é detectável no trofozoito (Potter e Weisman, 1971).

A produção de moléculas exóticas no encistamento é acompanhada por outras alterações metabólicas (Weisman e Moore, 1969; Krishna Murti, 1973) e morfológicas (Vickerman, 1962; Bowers e Korn, 1969; Pasternak et al., 1970), além do término do crescimento celular (Neff et al., 1964 b; Stevens e Pachler, 1973 b). 
As alterações no nível de macromoléculas que ocorrem no fim da ease logarítmica, antes do aumento da proporção de cistos, podem ser correlacionadas com eventos ligados ao encistamento. Células em fase estacionária possuem metade da quantidade de DNA verificada durante a fase logarítmica (Byers et al., 1969), fenômeno esse que coincide com a diminuição da velocidade de síntese de DNA (Rudick, 1971). A queda de 50\% no conteúdo de DNA por célula poderia ser explicada, admitindo-se que a maioria das amebas em fase logarítmica contivesse a quantidade de DNA da fase $G_{x_{2}}$ e que o ciclo de duplicação celular fosse inibido durante a fase estacionária, no período $G_{1}$, ou na transição entre os períodos $G_{1}$ e $S$. Essa hipótese foi reforçada pelos trabalhos de Neff e Neff (1969), Rudick (1971) e Band e Mohrlok (1973 b), que demonstram que o período $G_{2}$ constitui cerca de $80 \%$ do ciclo. de divisão celular. Situação semelhante foi verificada em Amoeba proteus. (Goldstein e Prescott, 1967). A conclusão adicional desses trabalhos é que a indução do encistamento dependeria da redução da quantidade de DNA por célula e que inibidores de sintese de DNA induziriam o encistamento. Por outro lado, outros autores (Griffiths e Hughes, 1969; Raizada e Krishna Murti, 1971), verificam inibição do encistamento por esses mesmos agentes. Experimentos recentes (Roti Roti e Stevens, 1973), demonstram também que, durante o encistamento, ocorre degradação de DNA sintetizado durante a fase de crescimento exponencial.

Os dados referentes à síntese de RNA durante o encistamento são igualmente contraditórios.Para alguns autores, o aparecimento de compostos peculiares ao cisto, seria uma indicação da necessidade de síntese de novas moléculas de RNA e proteína. Realmente, Rudick e Weisman (1973 a), verificam um acúmulo de RNA durante as primeiras 12 horas após indução.Posteriormente, a síntese de RNA é interrompida e 95\% do RNA sintetizado inicialmente é degradado. Stevens e Pachler (1973 a, b) apresentam resultados opostos, demonstrando que um acúmulo de RNA não é indispensável 
para a indução e que o RNA degradado é constítuido por espécies sintetizadas antes do encistamento. Segundo esses autores, a indução da diferenciação estaria intimamente relacionada com os eventos moleculares que regulam a divisão celular, já que o encistamento (espontâneo ou induzido) ocorre sempre em condições que determinam a inibição do crescimento.

Finalmente, o AMP cíclico parece estar relacionado com a indução do encistamento (Raizada e Krishna Murti, 1972 a). O AMP mimetiza a ação de taurina e cloreto de magnésio (Raizada e Krishna Murti, 1972 b), que ativariam uma adenil ciclase ligada à membrana. o aumento resultante da concentração intracelúlar de AMP cíclico, causaria a ativação das enzimas de sintese de celulose e mucopolissacarídios da parede do cisto (Krishna Murti, 1973).

Os cistos, quando transferidos para meio de crescimento, podem germinar (Griffiths e Hughes,1968) A ameba sai por um dos ostiolos presentes na parede do cisto e, a não ser pela formação desse pequeno orifício, a superfície do cisto permanece inalterada após o excistamento (Page, 1967; Chambers e Thompson, 1972). o excistamento parece não ser sincrônico e a extrusão da ameba é inibida por actinomicina D e cicloheximida, enquanto que inibidores de sintese de DNA não afetam 0 . processo (Mattar e Byers, 1971)。

2. Organização do genoma em eucariotos

DNA, cuidadosamente isolado de células ou tecidos, é constituido por moléculas bicatenárias, denominadas "nativas". A dupla hélice da molécula nativa pode dar origem a fitas separadas, com estrutura desordena da, através da ação de agentes químicos ou físicos que determinam o rompimento das forças que mantêm a dupla hélice. Esse processo de dissociação (ou desnaturação)é acompanhado por mudanças nas propriedades físicas do DNA: viscosidade, hipocromicidade, rotação óptica, den- 
sidade etc. A transição entre o estado nativo e desnaturado é abrupta, semelhante à fusão de um cristal, o que determinou a caracterização do processo pela temperatıra média da transição $\left(T_{m}\right)$. A largura da transição depende da origem do DNA, ou seja, DNA de virus, bactérias e vertebrados, apresentam intervalos de tran sição crescentes. Sob condjęões adequadas, as fitas complementares dissociadas podem formar moléculas estáveis com estrutura heljcoidal semelhante à nativa por um processo denominado renaturação ou reássociação (Marmur e Doty, 1961). É possível também verificar interação entre fitas de RNA e DNA, desde que existam sequências de bases complementares nos dois ácidos nucleicos, permitindo a formação de híbridos RNA-DNA.

A velocidade de renaturação depende da colisão de sequências de nucleotídios complementares e a reação obedecé cinética de segunda ordem em concentração de 1NA (Marmur et al., 1963; Britten e Kohne, 1967; Thrower e Peacocke, 1968; Wetmur e Davidson, 1968). O processo de renaturação pode ser acompanhado de diversas maneiras, sempre dependendo de alguma diferença física fácilmente detectável entre o DNA desnaturado e renaturado. Assim, é possível acompanhar a reassociação de DNA pela determinação da queda de absorbância a $260 \mathrm{~nm}$ durante a reação (Wetmur e David son, 1968), pela recombinação de fragmentos de DNA desnaturado com DNA de alto peso molecular fisicamente imobilizado em agar (Bolton, 1966) ou pela fração de DNA reassociado que se liga a colunas de fosfato de cálcio (hidroxiapatita) em diferentes tempos de reação (Britten e Kohne, 1967).

A velocidade da reação de renaturação é determinada pela concentração das sequências de núcleotídios presentes. Considerando-se diversos organismos, o DNA daquele com genoma maior, certamente conterá um número maior de sequências de nucleotidios diferentes. Assim sendo, a velocidade de reassociação fornece uma medida do tamanho do genoma de um organismo, desde que sejam mantidos constantes todos os demais fatores que influem na reação (temperatura,for- 
ça iônica, pH, viscosidade do solvente, tamanho dos fragmentos e teor de GC do DNA). Realmente, o tempo necessário para a obtenção de $50 \%$ de renaturação é inversamente proporcional ao tamanho do genoma (conteúdo haplóide de DNA por célula ou partícula de vírus) de bactérias e vírus (Britten e Kohne, 1967). No caso dos organismos superiores, imaginou-se, inicialmente, que o tamanho do genoma levaria a uma grande diluição das sequências individuais de nucleotídios e haveria, portanto, grande redução na velocidade de reassociação, quando comparada com a velocidade característica de DNA de bactérias. De fato, experiências iniciais não conseguiram evidenciar renaturação de DNA de timo de boi (Marmur e Doty, 1961). Posteriormente, através do emprego da técnica DNA-agar, verificou-se que DNA de organismos superiores reassociava efe tivamente, formando moléculas duplas especificas ( Hoyer et al., 1964). A explicação mais plausível para esse cato, até então inesperado, deveria se relacionar com a concentração de sequências capazes de renaturar, ou seja, o genoma de organismos superiores conteria populações de sequências de nucleotídios semelhantes ou idênticas (sequências repetidas ou reiteradas). Todos os organismos superiores analisados até hoje, contêm DNA repetido em proporções que variam, por exemplo, de $20 \%$ em ouriço do mar a $80 \%$ em salmão e trigo (cf. Britten, 1970). A lista de organismos que possuem DNA reiterado aumenta mui to, se forem considerados os trabalhos realizados inici almente, que utilizavam condições de reassociação ( tempo de incubação e concentração de DNA) que permitiam somente a renaturação de DNA repetido.

A renaturação do DNA de organismos mais simples como por exemplo Escherichia coli, segue cinética ideal de segunda ordem, obtendo-se uma curva hiperbólica com o decurso do tempo. A renaturação de DNA de organis mos superiores apresenta uma curva muito alargada, indicando a existência de componentes com velocidades de renaturação diferenteș. Uma fração do DNA de organismos superiores (DNA "único"), renatura com a velocidade prevista segundo o tamanho do genoma, por exemplo, em mamiferos, cerca de 600 vezes menor que a do DNA de E. coli. Assim 
sendo, paræ. DNA de bactérias e vírus e a fração de DNA "único" de organjsmos superiores, a complexidade cinética é igual à complexidade de sequência, ou seja, a quantidade de sequências diferentes em uma determinada amostra de DNA. E geralmente expressa em número de pares de nucleotídios ou número de daltons e corresponde ao termo "complexidade", definido por Wetmur e Davidson (1968). A complexidade cinética traduz, portanto, o tamanho do genoma de um organismo e mostra uma relação linear com a velocidade de reassociação (Britten.e Kohne, 1967; Wetmur e Davidson, 1968). A determinação da complexidade cinética do DNA único é prejudicada pela delimitação incerta da fração única e repetida de um DNA, que depende do critério de precisão de pareamento estabelecido durante a medida da velocidade de reassociação (Britten, 1971).

Apesar da maior parte do genoma bacteriano ser constituída por sequências que não se repetem ( sequências "únicas"), foi demonstrada a existência de uma pequena fração de DNA com baixa frequência de reiteração, respoñsável pela síntese de rRNA (Kohne, 1969), além de cópias múltiplas de DNA epissômico (Chiscon e Kohne, 1970).

A definição de eucariotos e procariotos,baseada principalmente na existência ou não de um núcleo verdadeiro, delimitado por uma membrana nuclear, pode, a partir do estudo da reassociação de ácidos nucleicos, ser formulada em outros termos: o DNA de procariotos é do tipo não repetitivo (exceto por pequenas quantidades de DNA ribossômico e epissômico), enquanto que o DNA de eucariotos é corstituído por sequências repetidas e sequências "únicas".

Uma familia de DNA reiterado pode ser caracterizada pelo número de.membros (frequência de reiteração), grau-de semelhança entre os elementos compo nenties e pela complexidade cinética.

A velocidade de reassociação das famílias de sequências repetidas estudadas varia de 30 (DNA de - ouriço do mar, Britten et al., 1972) a 10? vezes (DNA de cobaia, Southern, 1970) maion que a velocidade de 
reassociação de um DNA único. Esses dados ilustram a diversidade de frequências de reiteração encontradas hos organismos superiores.

A precisão do pareamento entre sequências repetidas reflete o grau de homologia existente entre as sequências e pode ser medida pela estabilidade térmica do par reassociado. Verifica-se um largo espectro de estabilidades térmicas, incluindo valores de $\mathrm{T}_{\mathrm{m}}$ de 1 a $40^{\circ} \mathrm{C}$ abaixo do $\mathrm{T}_{\mathrm{m}}$ de um DNA perfeitamente pareado. 0 grau de precisão de pareamento das sequências reiteradas é fundamentalmente determinado pelas condições de incubação: temperatura mais alta e força iônica mais baixa requerem maior precisão no pareamento, que resulta na formação de uma molécula dupla mais estável (Britten e Kohne, 1968; Rice e Paul, 1972). Nas reações entre DNAs de espécies diferentes, quando se pretende es tudar homologias entre famílias de DNA reiterado, há maior discriminação em temperaturas mais elevadas ( Martin e Hoyer, 1966).

A complexidade das famílias de DNA reiterado pode ser avaliada a partir da sua velocidade de reassociação. A complexidade cinética é uma medida operacional que pode ser obtida por comparação com a renaturação de um DNA padrão, como o de E. coli, com tamanho de genoma bem estabelecido (Cairns, 1963) e fornece uma medida do comprimento da sequência que foi originalmente replicada para formar a família de DNA reiterado. Entretan to, há uma certa imprecisão na interpretação da complexị dade cinética de uma família de DNA reiterado, em virtude do efeito do grau de semelhança entre os membros componentes, sobre a velocidade de reassociação.Britten e Bonner (1971) verificaram que o pareamento imperfeito, devido a presença de bases não complementares, reduz a velocidade de reassociação, podendo afetar significativa mente a interpretação de medidas de frequência de repetição ou grau de homologia entre espécies. Estudos paralelos de Southern (1970) e Sutton e McCallum ( 1971 ), demonstraram igualmente, que a velocidade de reassocia ̧̧ão de sequências semelhantes, mas não idênticas, fornece uma medida superestimada do comprimento real da uni- 
dade de repetição.

$\mathrm{Na}$ maioria dos eucariotos estudados, pode-se distinguir duas classes de DNA reiterado (Britten e Kohne, 1968): DNA altamente repetido ou de "sequência-simples " (Walker, 1971) e DNA de repetição "média" ou "intermediá-ria".

Os DNAs satélites são, provávelmente, os meLhores exemplos de familias de sequências de nucleotidios altamente repetidos. O satélite de camumdongo foi descri to em 1961 por Kit (1961) e Szybalski (citado em Walker, 1971), independentemente, como um componente menor, que se separa da banda principal do DNA em gradientes de cloreto de césio, em virtude de diferenças no contéúdo de GC. E encontrado em todos os tecidos, inclusive em células em cultura de tecido de várias linhagens de camundongo (Kit, 1961), representando 10\% do genoma. Renatura com velocidade muito grande (Waring e Britten, 1966) e a curva de renaturação se superpõe à uma curva ideal de segunda ordem, com uma inclinação que indica ausência de heterogeneidade interna. O DNA satélite nativo apresenta uma banda unimodal e estreita em gradientes de $\mathrm{CsCl}$, indicando que ocorre em longos segmentos de DNA, cada um contendo um grande número de elementos repetidos semelhantes (Walker, 1971). Baseados na relação linear entre o inverso do tamanho do genoma e a velocidade de reassociação, Waring e Britten (1966), propuseram que o satélite deveria ser cons tituído por cerca de $10^{6}$ cópias extremamente semelhantes de um segmento de aproximadamente 300 nucleotídios de comprimento. Por outro lado, Southern (citado em Britten, 1971), através da análise parcial da sequência de bases, sugeriu que o satélite de camundongo poderia ser formado por uma unidade de repetição muito pequena, da ordem de 10 a $12 \cdot$ nucleotídios, extremamente modificada ao longo da evolução: Britten (1971), analisando os dados obtidos por Southern, concluiu que se a repetição interna de um frag mento curto realmente existiu, ela não é mais detectável cinèticamente, podendo evidenciar-se apenas a repetição plincipal do DNA satélite. Todavia, a interpretação desses resultados torna-se cada vez mais difícil, levando-se em consideração a descoberta de outros satélites em mamíferós 
(Southern, 1970) e Drosophila (Peacock et al., 1973 ; Gall et al., 1973) que, segundo a análise da estrutura primária e ação de enzimas de restrição (Southern e Roizes, 1973), parecem ser constituídos pela repetição de segmentos contendo 5 a 7 nucleotídios. Portanto, a sequência original dos DNAs satélites parece ser muito pequena, mas a introdução de mutações nessa sequencia, faz com que ela se comporte, durante a reassociação, como se fôsse muito mais longa.

- DNA satélite de vários eucariotos parece estar sempre associado à fração heterocromática (Yasmineh e Yunes, 1970). O emprego da técnica de hibridiza ção de ácidos nucleicos "in situ" (Jones, 1970; Pardue e Gall, 1969), permitiu demonstrar DNA altamente repetido associado aos centrômeros de cromossomos metafásicos, nucléolos e grânulos de cromatina de núcleos interfásicos. As sequências satélites são geralmente encontradas nas regiões heterocromáticas dos cromossomos, com exceção do cromossomo $\mathrm{Y}$ de camundongo (Pardue e Gall, 1970) e de algumas espécies de Drosophila. (Hennig, 1972). Rudkin (1969) demonstrou que, durante a formação de núcleos politênicos, há uma sub-replicação da heterocromatina em relação à replicação de regiões eucromáticas. Consequentemente, o DNA satélite não é replica do durante a formação dos cromossomos politênicos, ou, pelo menos, não é replicado proporcionalmente ao resto do genoma (Gall et al., 1973). Em células de camundongo, com divisão sincronizada, o satélite é sintetiza do na fase $S$ tardia, enquanto que as frações do genoma ricas em GC, são replicadas logo no início. Esses dados concordam com a localização heterocromática das sequências satélites, já que a heterocromatina é replicada tardiamente durante a fase $S$ (Walker, 1971)。

A simplicidade de sequência dos DNAs satélites, sugere que eles não possam funcionar como genes estruturais, apesar de Skinner e Kerr (1971) terem proposto que o satélite AT de caranguejo fôsse o responsável pela síntese de uma proteína específica. O satélite de camundongo não é transcrito (Flamm et al., 1969) e a análise da sequencia de bases do satêlite $\alpha$ de co- 
baia (Southern, 1970), mostra que vários dos possiveis codons são "non-sense", tornando pouco provável que essas sequências sejam traduzidas em proteína.

Em vários organismos superiores, existe uma fração do DNA altamente reiterado que mimetiza o comportamento de moléculas bicatenárias, após incubação em condições que não permitem reassociação por colisão bimolecular (Davidson et al., 1973). Esse tipo de DNA com renaturação "instantânea" (ou "espontânea"), possui metade de suas bases pareadas e encontra-se distribuído ao longo do genoma, mostrando uma certa dependência na composição de bases das regiões adjacentes (Bonner,1973). Existem evidências de que se relacionem topogràficamente com DNA reiterado, pois ocorrem com alta frequência no satélite de camundongo (Flamm et al., 1969). A renaturação espontânea poderia resultar da existência de "crosslinking" (Alberts e Doty, 1968; Mulder e Doty, 1968) ou de sequências parcialmente complementares ao longo da mesma fita de DNA (Flamm et al., 1969; Britten e Smith, 1970; Bonner, 1973).

O segundo tipo de DNA reiterado encontrado nos eucariotos; é definido por critérios cinéticos e,exceto alguns casos especiais (Corneo et al., 1970), só pode ser isolado como uma fração de DNA reassociado.Essa fração renatura mais lentamente que as sequências satélites, mas mais depressa que sequências que ocorrem uma ou poucas vezes no genoma. O DNA de "repetição interme diária" (ou DNA "intermediário"), contém as sequências que hibridizam com RN:A em experimentos que empregam baixa concentração de ácidos nucleicos. De fato, as experiências de hibridização realizadas inicialmente, devido às condições de incubação empregadas, mediam sòmente à homologia entre sequências de RNA e sequências de DNA repetido (Melli a Bishop, 1969; Britten, 1970).

As sequências ccm reiteração intermediária, ao contrário das sequências satélites, parecem estar dispersas ao longo do genoma (Eritten e Smith, 1970), em regiões de eucromatina e heterocromatina (Pardue e Gall, 1969; John et al., 1969, Jones e Robertsor,1970; Hennig 
et al., 1970), sendo representadas em tecidos politênicos (Gall et al., 1971). Os cistrons para rRNA e tRNA pertencem à fração de DNA "intermediário".

o número de cistrons ribossômicos aumenta ao longo da escala evolutiva, paralelamente ao aumento do genoma dos organismos. Valores máximos de multiplici dade são encontrados em ovócitos de insetos e anfíbios, como consequência de processos de amplificação gê nica (Birnstiel et al.,1971). Os trabalhos iniciais com Xenopus (Brown e Gurdon, 1964) e Drosophila (Ritossa e Spiegelman, 1965), serviram de suporte para a identificação do organizador do nucléolo como o locus para os cistrons ribossômicos redundantes (Gambarini, 1972), posteriormente confirmada por hibridização "in situ" (Pardue et al., 1970). Como os cistrons de rRNA em eucariotos são intensamente agrupados e, geralmente, possuem alto teor de GC, podem aparecer como satélites em gradientes de $\mathrm{CsCl}$, facilitando o seu isolamento. Em bactérias", a obtenção de rDNA é dificultada pela presença de sequências espaçadoras com composiçäo de bases mediana. Entretanto, Kohne (1969) e Colli e Oishi (1970), consegujram o isolamento de rDNA de E. coli e Bacillus subtilis respectivamente.

Na maioria dos eucariotos estudados, os cistrons para rRNA $18 \mathrm{~S}$ e 28S, são intercalados por sequências reiteradas com alto teor de GC, denominadas se quências espaçadoraș (Birnstiel et al., 1968; Brown e Weber, 1968). O rDNA contém, adicionalmente, uma fração que é transcrita e posterịormente perdida, durante o processamento do rRNA (Loening et al., 1969). As sequências espaçadoras não são transcritas (Hallberg e Brown, 1969) e sua função é desconhecida.

Os genes que codificam para RNA ribossômico $5 \mathrm{~S}$ e RNA de transferência também são reiterados e intercalados por sequências espaçadoras (Birnstiel et al., 1971). Ao contrário dos cistrons de rRNA 18s e 28S, não estão confinados ao organizador do nucléolo (Wimber e Steffensen, 1970; Steffensen e Wimber, 1971 ; Pardue et al., 1973). 
A transcriçăo de DNA reitierado foi demonstrada em outros casos, onde as sequências repetidas estavam representadas em RNA estritamente nuclear (Melli e Bishop, 1969, 1970; Melli et al., 1971; Balsamo et a1., 1973) e em RNA mensageiro de histonas (Kedes e Birnstiel, 1971).

A cinética de renaturação em diferentes eucariotos demonstra que, em todas as espécies estudadas, há uma fração considerável de DNA "único" que contém, provàvelmente, a maior parte dos genes estruturais. Modificações da técnica de hibridização RNA-DNA, permitem estudar a expressao de sequências"únicas" de DNA (Melli et al., 1971; Gelderman et al., 1972; Firtel et al., 1972). Estudos recentes de Paul et al. (1973), Bishop e Freeman (1973) e Crippa et al. (1973), indicam que os loci responsáveis pela transcrição de mRNAs bem caracterizados (mRNA de hemoglobina de pato e camundongo e mRNA de polissomos de nêurula de Xenopus), pertencem à fração de DNA "único". Além disso, os resultados sugrerem que esses RNAS mensageiros possuem, na extremidade 5', sequências reiteradas, transcritas do DNA intermediário, além do segmento de poli-A na extremidade $3^{\prime}$.

As experiências de renaturação de DNA de organismos superiores, empregando fragmentos de diferentes tamanhos, indicam conclusões gerais sobre o arranjo das sequências: ao longo da maior parte do genoma, as sequências únicas se alternam com as sequências repetidas (Davidson et al., 1973; Graham et al., 1973).

Atualmente, a hipótese mais aceita sobre a organização do DNA cromossômico de eucariotos, propõe que cada cromossomo contenha uma única molécula bicatenária de DNA (cf。Swift, 1973). Os cromômeros, identifí cados com as bandas dos cromossomos politênicos, são considerados como as menores unidades estruturais. Várias evidências sugerem que sòmente uma função genética seja associada a cada bandá que, porém, contém muito mais DNA que o necessário para codificar uma molécu- 
la de proteína de tamanho médio. Realmente, ó núcleo de muitos organismos superiores parece conter DNA que, aparentemente, não é funcional. Em Drosophila, uma fração razoável do cromômero parece não ser essencial para o desenvolvimento de um caráter fenotípico (Sorsa et al., 1973).

Thomas (1970) sugere que a estrutura do cromômero e o problema do excesso de DNA poderiam ser explicados se se postulasse que os cromômeros fôssem constituidos por famílias de repetições idênticas enfileiradas, conforme originalmente proposto por Callan (1967). O suporte experimental para essa hipótese, originou-se de trabalhos de Thomas et al. (1970), que observaram ao microscópio eletrônico, a formação de circulos estáveis após tratamento de DNA nativo com exonucleasse, ou depois da renaturação de DNA desnaturado. I A formação de círculos seria consequência da existêncią de sequências idênticas ac longo da molécula de DNA. Posteriormente, Thomas et al. (1973), confirmaram a homologia existente entre essas sequências, através da verificaçẫo da grande estabilidade térmica da região dupla que determina a formação do círculo. Portanto, segundo eşa hipótese, cada locus gênico dos eucariotos ocorre ria como uma série linear de sequências idênticas. Essa teoria contraria a existência, cada vez mais comprovada, de sequências "únicas" no DNA de eucariotos. Provàvelmen te, a formação de círculos é devida às sequências com repetiçao grande ou intermediária, intercaladas entre as sequências únicas. A produção de circulos não deve ser considerada como evidência para a existência de uma estrutura básica de repetições em todos os cromôme ros de um cromossomo. Em alguns casos especiais, como os loci que codificam para histona, podem ocorrer regiões de genes estruturais repetidos, conforme proposto por Thomas (1970).

Apesar da quantidade de informações acumuladas sobre a estruturé e distribuição das sequências reiteradas, nada se sabe sobre o mecanismo molecular que poderia criar esse tipo de sequência, nem sobre sua 
possivel função biológica. Segundo Walker (1971), a presença de sequências repetidas proporcionaria uma certa vantagem seletiva aos cromossomos, porque há evidências que, durante a meiose, o comportamento dos cromossomos seja afetado pela natureza e quantidade da heterocromati na adjacente aos centrômeros. Todavia, atualmente, procura-se atribuir um papel de regulação ao DNA reiterado.

A maioria dos modelos propostos para a organização dos cromoșsomos de eucariotos enfatiza a necessidade de sitios de controle adjacentes aos genes estruturais, tendo em vista a "interdispersão" de DNA "úni co" e repetido. Os sitios de controle seriam constituí-dos por sequências reiteradas.

Trabalhos de difração de raios $X$ demonstram que a estrutura secundária do DNA varia com a composiçao de bases: DNA muito rico em AT parece não adotar a configuração B, característica para DNA com teor baixo ou moderado de AT (Bram, 1971). En Drosophila, satélites com razões de bases diferentes, são sub-replicados diferencialmente durante a politenizaçao. Como a estrutura secundária do DNA é uma função da sua composição de bases, postula-se que os satélites e outras sequências repetidas apresentariam conformações diferentes que permitiriam o reconhecimento por proteínas reguladoras e a não replicação de segmentos específicos do genoma (BIumenfeld e Forrest, 1972)。

Britten e Davidson (1969) e Georgiev (1969) sugerem que o DNA intermediário seja responsável pela regulação da diferenciação. Os primeiros supõem que moléculas de RNA exclusivamente nuclear seriam o produto de genes reguladores que não seriam traduzidos. No modelo de Georgiev, o RNA nuclear de alto peso molecular con teria a informação para a síntese de proteínas reguladoras, semelhantes aos repressores bacterianos. A demonstração da transcrição de sequências intermediárias em moléculas de RNA exclusivamente nuclear e o comprimento das sequências unicas e repetidas intercaladas, säo consistentes com o modelo de Britten e Davidson(1969;).Crick (1971), baseado na hipótese formulada por esses autores, 
elabora um modelo que distingue duas classes de DNA: DNA globular, com função de controle e uma fração menor de DNA fibroso, que codificaria a síntese de proteínas. Os sitios de controle conteriam regiões não pareadas, provàvelmente de poli A, que poderiam reagir com outras regiões semelhantes pertencentes a uma banda da mesma cromátide. Essa situação deveria ser encontrada nas sequências satélites altamente repetidas da heterocromatina próxima aos centrômeros. Esses sitios seriam os mediadores do alinhamento das bandas dos cromossomos politênicos. Segundo Paul (1972), regiões de nucleoproteina densamente enovelada (correspondentes ao DNA "globular" de Crick, 1971) se alternariam com regiões de nucleoproteina menos compacta. Proteinas năo histônicas se ligariam a sitios múltiplos no DNA("adress sites") e causariam um desdobramento parcial da nucleoproteína, possibilitando a ligação de RNA polimerase a sítios promotores adjacentes. Os "adress sites" seriam formados pelas sequências repetidas.

A análise da reassociação das sequências de nucleotídios encontradas nos roedores (Flamm et al., 1969; Hennig e Walker, 1970; Rice, 1971a,b; Rice e Straus, 1972) e em outros grupos de animais (Britten e Kohne, 1967; Britten e Smith, 1971) e plantas superio res (Bolton, 1966) permite definir afinidades taxonômicas através da homologia genética ao nível molecular e estabelecer possíveis relações evolutivas. Uma fração do DNA intermediário dos eucariotos é comum a espécies relacionadas e produz moléculas duplas homólogas ou heterólogas com baixa estabilidade térmica, sugerindo um certo grau de divergência entre as sequências repetidas. O rDNA constitui um grupo muito especial de sequências com repetição intermediária. Ao contrário do resto do genuma, os cistrons ribossômicos de bactérias e eucariotos hibridizam com DNA heterólogo, formando moléculas duplas perfeitamente pareadas(Birnstiel et al., 1971). Enquanto essas sequências foram extremamente conservadas ao longo da evolução, o DNA espaçador, não transcrito, mostra grande divergëncia , mesmo em espécies do mesmo gênero, como no caso de Xenopus laevis e mulleri (Brown et al., 1972). 
A constância das sequências ribossômicas contrasta com a grance variabilidade dos satélites, que parecem ser especifícos para cada espécie ( Flamm et al., 1969; Hennig e Walker, 1970; Britten e Smith, 1971; Rice e Straus, 1972). Satélites do grupo de Drosophila virilis (Gall et al., 1973), ao contrărio do satélite de camundongo e do satélite $x$ de cobaia, são muito homogêneos. Os satélites mais recentes originaram-se por uma única substituição de base em cada sequência repetida. No caso dos satélites, a seleção não poderia ser responsável pela conservação, já que essas sequências não são, aparentemente, transcritas ou traduzidas. Atualmente, propõem-se mecanismos para a manutenção da homogeneidade dessas sequên-cias, os quais impediriam o acúmulo de mutaçōes e também explicariam a introdução de mudanças regulares de bases, conforme verificado nos satélites de algumas es pécies de Drosophila (Gall et al., 1973).

A formação das famílias de DNA reiterado é explicada por dois mecanismos. Southern (1970), sugere que a estrutura atual do satélite $\alpha$ de cobaia po deria ser resultante do duplicações sucessivas de uma sequência ancestral e introdução posterior de mutações. Os satélites do grupo virilis exemplificam o tipo de sequência postulada como precursora dos satéli tes de camundongo e de cobaia.

A ocorrência escassa de DNA com baixa frequência de reiteração sugeriu a Britten e Kohne (1968) que a duplicação ao acaso não poderia produzir o padrão de frequências de repetição encontrado nos eucariotos. Aparentemente, certas sequências seriam favorecidas pela duplicação que ocorreria através de "replicação saltatória". Segundo esse mecanismo, uma sequência original de DNA seria, subitamente, ao longo da evolução, replicada muitas vezes, formando uma família de sequências idênticas. Os membros dessa familia sofreriam mutações e translocaçōes para outros segmentos do cromossomo ou para outros cromossomos, originando uma familia de sequências semelhantes, mas não idênticas. Posterior divergência faria com que não fôsse mais possível detectar homologia en tre essas sequências que seriam indistinguíveis da 
sequência original de DNA. O processo de formação de uma familia seria muito rápido em relação à velocidade de mutação. A idade de uma família pode ser estimada através da divergência entre seus membros. Segundo o modelo da replicação saltatória, novas famílias estariam constantemente surgindo ao longo da evolução. Famílias originadas recentemente, como os satélites, seriam limitadas sòmente a.uma espécie e seus membros seriam pràticamente iguais. Uma família formada há muito tempo, seria encontrada atualmente em espécies distantes e haveria grande divergência entre seus membros. A razão entre a quantidade de DNA não homólogo entre duas espécies e o tempo desde a divergência dessas espécies, fornece uma medica da velocidade de introdução de novas famílias de DNA repetido no genoma. Essa velocidade se refere somente às familias que foram fixadas no genoma da espécie e não deve ser interpretada co mo a velocidade de crescimento do genoma, porque muitas famílias podem não ter sido fixadas e nada se sabe sobre a velocidade de perda de DNA durante a evolução de uma espécie. Outros mecanismos para crescimento do Genoma como poliploidia ou politenia, tenderiam a aumentar a cortribuição devida a eventos saltatórios (Kohne, 1971).

A reassociação de DNA pode, portanto, ser utilizada para estudar o grau de divergência evolutiva entre vários sistemas biológicos, permitindo estabele cer uma correlação com os dados paleontológicos. Os resultados sugerem que, durante o processo de replicação, ocorrem alterações genéticas ("replicação saltatória") com velocidade suficientemente grande para serem detectadas contra um "background" corıtínuo de mudanças que envolvem um único par de bases (Kohne et al., 1971).

A análise da sequência de aminoácidos de proteínas homólogas de espécies diferentes, permite avaliar a velocidade de substituição de aminoácidos. A comparação entre a velocidade de evolução de proteínas e BNA (Laird et al., 1969) fornece resultados de difícil interpretação, porque não se conhece a fração do DNA de organismos superiores que codifica para proteí- 
na. Grande parte do DNA analisado pode não tèr expressão genética e, consequentemente, não ter sido conservado. Por outro lado, as proteínas estudadas geralmente têm funções celiulares específicas, ou seja, são genèticamente importantes e aptas a serem conservadas ( Kohne et a1., 1971).

3. Caracterizaçăo do genoma de A. castellanii

o princípio biológico da continuidade germinal exclui a possibilidade de que a diferenciação envolva distribuição diferencial de DNA entre tecidos ou células em diferentes estágios de diferenciação. Aplicações de técnicas de hibridização RNA-DNA, permitem isolar as sequências de DNA expressas em RNA. O conhecimento da fração de DNA expresso tem siro utilizado para detectar amplificação gênica em tecidos adultos ou fetais (Kohne e Byers, 1971) e os resultados obtidos excluem a existência de amplificação, pelo menos, em larga escala. Além disso, a análise da atividade gênica ao longo da ontogênese demonstra que todas as sequências de DNA estão igualmente representadas em todos tecidos adul tos, embrionários e transformados de mamíferos (Bolton, 1966). Por outro lako, a população de moléculas de RNA de diferentes órgãos adultos e fetais diferem na qualidade e na quantidade. A medida que ocorre a diferencia ção de larvas de Xenopus, verifica-se que o RNA produzido cada vez mais se assemelha ao RNA da larva totalmente desenvolvida (Bolton, 1966). Esses resultados corroboram a idéia fundamenta] de que a diferenciação implica na atividade diferencial do genoma, através da produção de populações distintas de moléculas de RNA (Jacob e Monod, 1963). Todavia, em certos organismos como Rhyncosciara e Sciara, há evidências de replicação diferen cial do genoma (Breuer e Pavan, 1955; Crouse e Keyl, 1968; Meneghini et al., 1971). A partir dessas evidênias, formulou-se a hipótese de que a alieraça do potencial grnético dos seres vivos, fàcilmente detectada 
em alguns organismos, poderia constituir um mecanismo genérico de citodiferenciação (Pavan, 1965). Entretanto, a ampliflcação gênica, como mecanismo do desenvolvimento, talvez seja restrita a situações onde grande quantidade de um produto gênico específico seja necessária, como na ovogênese de anfíbios (Birnstiel et a1., 1971) e insetos (Gall et al., 1969; Iima-de-Faria, 1973), ou na "magnificação" de rDNA em mutantes "bobbed" de Drosophila (Ritossa, 1972). Entretanto, a descrição de mecanismos sofisticados de citodiferencia ção mostra que as generalizações devem ser analisadas criticamente. En certos organismos, verifica-se eliminação seletiva de cromatina (cf。Balsamo, 1972) ou de DNA altamente repetido, como acontece am Ascaris (Modak, 1973). Durante a formação do macronúcleo de ciliados (Prescott e Krishna Murti, 1973), hà destruição de $80 \%$ do DNA e as novas moléculas são sintetiza das a partir de pequenos fragmentos restantes de DNA, que contém todas as informações necessárias para a manutenção, crescimento e divisão das células.

Trabalhos antigos sobre a diferenciação de A. castellanij (Volkonsky, 1931), mostraram que, 1ogo no inicio do encistamento, havia uma expulsão par cial de cromatina periférica para o citoplasma adjacen te ao núcleo. 0 material foi caracterizado como DNA, de vido à reação de Feulgen positiva. Em vistos mais veIhos, essa zona desaparecia, devido à migração do ácido nucleico para a membrana externa do cisto. Observava-se, também, a saída de grânulos basófilos do nucléo 1o, que se acumulavam inicialmente no nucleoplasma pró ximo à membrana nuclear e depois migravam para o citoplasma, onde desapareciam gradativamente.Posteriormente, através de microscopia eletrônica, Bowers e Korn (1969) verificaram que o volume nuclear diminuia 40\% durante o encistamento: no início do processo, o núcleo tornava-se 1obado, formando pequenos botões que pareciam não conter material nucleolar. Grande parte dos botões era incorporada em autolisossomos, característicos de células encistantes. Além disso, parte do material densamente corado do nucléolo, parecia se dispersar no nucleoplasma e seu destino posterior era 
difícil de ser determinado morfológicamente. o decrés cimo nucleolar; igual a 75\% durante o encistamento (Ray e Hayes, 1954), era paralelo à expulsão de cromatina.

- Chang e Humes (1962) isolaram um fator transferível para células humanas em cultura de tecido, denominado "lipovírus". Trabalhos posteriores ( Chang et al., 1966), sugeriram que o"lipovírus" era transportado por uma célula amebóide, capaz de transferí-lo para células humanas crescendo "in vitro", por um mecanismo desconhecido que exigia o contato entre as células. O fator transferível sofria replicação na célula hospedeira, causando alterações nucleares (degradação de DNA), produção de antígenos específicos e lise celular. A injeção intracerebral das células amebóides com seu fator transferível, em macacos, causava encefalite. As células amebóides foram, então, identificadas como Hartmannella rhysodes (Acanthamoeba sp.). A observação direta do efeito patológico dessas amebas e a demonstra ção, por imunofluorescência, de antígenos das amebas nas células hospedeiras (Liu e Rodina, 1966), sugeriram que Acanthamoeba transportava um fator transferível, de natureza desconhecida. Ito e colaboradores (1969) postularam que o fator transferível poderia ser o responsável por parte da incorporação citoplașmática de timidina tritiada verificada anteriormente (Chang et al., 1966). Análise estrutural fina, através de autoradiogra fia em trofozoitos de Acanthamoeba (Ito et al。, 1969) demonstrou incorporação ativa de timidina tritiada no citoplasma, enquanto que a marcação nuclear era relativamente limitada: cerca de $32 \%$ da radioatividade era encontrada no citoplasma e o número de grãos contados sobre o plasmalema era três vezes maior do que sobre as mitocôndrias. A Iinhagem de Acanthamoeba utilizada por Ito et al. (1969), foi propagada durante anos em culturas axênicas, tornando, portanto, pouco provável que os corpísculos citoplasmáticos resultassem da introdução de microrganismos exógenos. Em duas linhagens de Naegleria gruberi, ameba de solo relacionada taxonômicamente com A. castellanii, foi demonstrada a existência de partícula.s semelhantes a vírus ao microscópio 
eletrônico, capazes de infectar células de embrião de galinha, ocasionando lise e liberação de maior quantidade de material infectante (Dunnebacke e Schuster, 1971). Em Acanthamoeba, os corpúsculos citoplasmáticos contendo DNA poderiam ser elementos genéticos normais do genoma da ameba, endosimbiontes facultativos ou parasitas intra-celulares como vírus defectivos ou epissomos (Ito et al., 1969). A existência provável desses elementos se relaciona com a verificação anterior de um fator transferível nessa linhagem.

A descrição da expulsão de cromatina e a presença de endósimbiontes citoplasmáticos pođem, de alguma maneira, estar relacionadas. Nos estágios iniciais do encistamento, verifica-se o aparecimento de autolisossomos no citoplasma, contendo mitocôndrias, grâ nulos de glicogênio etc. (Bowers e Korn, 1969). Os cistos apresentam agregados de restos citoplasmáticos aderidos à camada externa da parede do cisto, sugerindo que o conteúdo dos autolisossomos seja descarregado na parede em.formação (cf. Bowers e Korn, 1969). Autólise e excreção de componentes citoplasmáticos e nucleares são consistentes com o aparecimento de proteínas, aminoácidos e ribonucleotídeos no meio de cultura de células encistantes (Griffiths e Hughes, 1968). 0 material excretado contém, ao microscópio eletrônico, ,. partículas semelhantes a vírus (Bowers e Korn, 1969). Fenômeno semelhante à liberação de cromatina em A. castellanii, foi verificado durante a ovogênese de insetos do gênero Acheta, conforme trabalhos recentes de Lima-de-Faria e colaboradores (cf. Lima-deFaria, 1973). Durante a meiose, nesses organismos, há amplificação de certos cromômeros que liberam. as cópias amplificadas no nucleoplasma. Subsequentemente, esse DNA se dirige para as proximidades do envelope nuclear e força sua passagem para o citoplasma, ficando envolvido por uma parte da membrana nuclear. Através de hibridização "in situ", demonstra-se que a maior parte do material amplificado é formado por cistrons ribossômicos. O DNA migra para o citoplasma acompanha do por grande quantidade de RNA. Os dois tipos de áci- 
dos nucleicos permanecem associados no citoplasma, formando grandes partículas de função desconhecida. Essa transferência de complexos DNA-RNA também foi verificada em outras espécies de insetos (Jaworska, citado em Lima-de-Faria, 1973) e rato (Izquierdo e Vial, 1962 ; Szollosi, 1965, citados em Lima-de-Faria, 1973).

o encistamento em amebas pode ser considerado como um processo de diferenciação celular típica, não complicado por processos sexuais (Neff et al., 1964 a). Muitos sistemas biológicos têm sido explorados, na tentativa de elucidar os eventos metabólicos que determinam a regulação do crescimento e diferenciação ce lular. O encistamento pode constituir um sistema útil para o estudo da morfogênese celular, já que os tipos celulares envolvidos são distintos estrutural e químicamente e o processo pode ser acompanhado sob condições experimentais bem definidas. Apesar de representar um exemplo de diferenciação de protozoártos, pode servir como um modelo simples para a compreensão do desenvolvimento de sistemas evolutivos mais complexos, com os quais compartilha características comuns (Krishna Murti, 1971; Stevens e Pachler, 1973 a).

Assim, a simplicidade relativa do sistema de A. castellaniï, a facilidade de ser cultivada axênicamente em larga escala e a possibilidade de ser encistada sincronicamente, motivaram o estudo da diferencia ção dessa ameba. Tendo em vista as mudanças nucleares paralelas ao encistamento, a idéia inicial deste trabatho era analisar o padrão de sequências de DNA nas duas fases do ciclo de vida do protozoário. o objetivo era explorar as interações entre os ácidos nucleicos do cisto e trofozoito, através da homologia entre seus DNAs . Especulações como essas poderiam fornecer resultados interessantes sobre o papel biológico das diferentes familias de DNA presentes nos organismos superiores; já que a diferenciação da ameba envolve, provavelmente, perda de parte do material genético. A caracterização do DNA de trofozoito sugeriu vários problemas que passaram, então, a, ser estudados. Padronizou-se um método de isolamento de núcleos dessa ameba (Marzzoco e Colli, 1974) 
e de extração de DNA de trofozoitos e cistos. A análise do DNA de trofozoitos quanto ao comportamento em gradientes de densidade, perfil de desnaturação e renatura ção, forneceu resultados que podem se relacionar com a descrição citológica de dorpúsculos citoplasmáticos contendo DNA (Ito et al.,1969) e com a extrusão de DNA para o citoplasma (Bowers e Korn, 1969). Deste modo, o trabalho a ser descrito representa a caracterização parcial do DNA de trofozoito e uma análise preliminar do DNA de cisto. Os resultados obtidos poderão, futuramente, servir para o estudo da homologia existente entre esses ácidos nucleicos, o que poderia ser útil para uma melhor compreensão da diversificação gênica durante o ciclo de vida de um organismo superior relativamente simples. 


\section{Métodos}

\section{Crescimento de A. castellanii}

a) Meios de crescimento

o crescimento da ameba foi testado em dois meios de cultura, resultantes de modificações dos meios descritos por Neff (1957) e Band (1959). A composição dos meios empregados, denominados $\mathrm{A}$ e $\mathrm{B}$ era a seguinte:

Meio A

proteose-peptona - $0,75 \%$

extrato de levedo - $0,75 \%$

glicose - $1,5 \%$

$\mathrm{MgSO}_{4}-\operatorname{lmM}$

$\mathrm{CaCl}_{2}-0,05 \mathrm{mM}$

$\mathrm{KH}_{2} \mathrm{PO}_{4}-2 \mathrm{mM}$

citrato férrico - 0,ImM
Meio B

proteose-peptona - 1,5\%

glicose $-1,0 \%$

$\mathrm{NaCl}-2 \mathrm{mM}$

$\mathrm{MgCl}_{2}-0,015 \mathrm{mM}$

$\mathrm{CaCl}_{2}-0,02 \mathrm{mM}$

$\mathrm{FeSO}_{4}-0,01 \mathrm{mM}$

$\mathrm{Na}_{2} \mathrm{HPO}_{4}-\mathrm{ImM}$

$\mathrm{KH}_{2} \mathrm{PO}_{4}-\mathrm{ImM}$

Os dois meios continham ainda, as seguintes vitaminas: tiamina $(1 \mathrm{mg} / 1)$, biotina $(0,2 \mathrm{mg} / 1)$ e vitamina $B_{12}(1 \mu \mathrm{g} / 1)$.

A preparação dos meios de cultura seguia o procedimento descrito abaixo, necessário para evitar a formação de resíduos ínsolúveis, ricos em nitrogênio, após a autoclavagem.

O meio, com pH igual a 7,0, não contendo gli cose e vitaminas, era fervido durante 20 minutos. Após resfriamento, as vitaminas eram adicionadas e o meio filtrado através de papel de filtro fino. O líquido trans parente resultante era distribuido em frascos de cultura e autoclavado a $120^{\circ} \mathrm{C}, 1 \mathrm{~kg} / \mathrm{cm}^{2}$, durante 30 minutos. Antes do inóculo, glicose 50\%, autoclavada à parte, era 
adicionada assèpticamente, no volume adequado. Em alguns casos, adicionava-se $100 \mu \mathrm{g} / \mathrm{ml}$ de penicilina e estreptomicina, prèviamente esterilizadas por passagem em filtros Millipore GS autoclavados.

\section{b) Tratamento dos frascos de cultura}

As amebas aderem firmemente a superfícies, - que dificulta a obtenção de dados quantitativos sobre o crescimento. O uso de vidraria tratada com silicone evita esse problema, sem causar nenhum dano às células (Neff et al., 1958). Os frascos de cultura, limpos e secos, eram siliconizados com uma solução $5 \%$ de silicone e secos a $220^{\circ} \mathrm{C}$ por cerca de 16 horas.

\section{c) Métodos de cultura}

A cultura era sempre feita a $28^{\circ} \mathrm{C}$, de diversas maneiras:

Culturas estacionárias: as amebas eram crescidas em culturas rasas, obtidas com erlenmeyers contendo um volume de meio igual a $1 / 5$ da capacidade do frasco. Esse tipó de cultivo era utilizado para manutenção de culturas-estoque.

Culturas agitadas: amebas cultivadas em. erlenmeyers, mantendo a mesma relação de volume ( $5: 1$ ), eram incubadas em agitadores New Brunswick, com velocidade em torno de $100 \mathrm{rpm}$. O crescimento em pequena escala, podia ser obtido por incubação de pequeno volume de meio (cerca de $2 \mathrm{ml}$ ), em tubos inclinados sob agitação.

Cultura em larga escala: para a obtenção de grandes quantidades de células, adotaram-se diferentes processos de cultivo: crescimento em frascos de 121 , contendo 11 de meio, incubados estaticamente ; crescimento jegundo Adam et al.(1969), onde a aeração era obtida colocando-se frascos de 3 a 61 , contendo imã, sobre agitadores magnéticos e cultivo em fermenta- 
dor (New Brunswick Sci. Co. Inc.), com uma dorna de 81 , contendo 51 de meio, aeração de 21 de ar por minuto e agitação de $80 \mathrm{rpm}$.

d) Determinação da velocidade de crescimen to

O crescimento era medido pelo número de células por ml de meio, por tempo de cultivo. o número de células era determinado por contagem de amostras tri plicatas em câmara tipo Neubauer (Resistance, Germ):Alternativamente, o crescimento era determinado pela absorbância a $600 \mathrm{~nm}$, em um espectrofotômetro Coleman Jr. II, utilizando-se frascos de cultura com um tubo de ensaio adaptado lateralmente.

\section{e) Manipulaşão de culturas}

As operações, após autoclavagem dos frascos, eram realizadas em câmara assèptica. o coṇtrole de contaminação das culturas era realizado por pré-incubação dos frascos estéreis a $37^{\circ} \mathrm{C}, 16$ horas; verificação de crescimento bacteriano por adição de alíquotas do meio de crescimento em caldo glicosado, incubado a $37^{\circ} \mathrm{C}$. por 16 horas e coloração do meio de crescimento estéril pelo método de Gram.

\section{Encistamento}

o encistamento era induzido por remoção das células do meio de crescimento, lavagem e transferência para um meio de encistamento semelhante ao descrito por Neff et al. ( 1964 b ), com a seguinte composiçăo: $\mathrm{KCl} 100 \mathrm{mM} ; \mathrm{MgSO}_{4} 8 \mathrm{mM} ; \mathrm{CaCl}_{2} 0,4 \mathrm{mM} ; \mathrm{NaHCO}_{3}$ ImM e tampão Tris-HCl $20 \mathrm{mM}, \mathrm{pH}$ 9,0. O meio de encistamento era autoclavado nas mesmas condições que o meio de crescimento e todas operações eram realizadas assèpticamente. Células de culturas agitadas em fase logarítmica tardia, eram coletadas por centrifugação (800xg; 
10 min.) e lavadas três veres com meio de encigtamento.

Hon segulda, as células eram suspensas em meio de encistamento, ao nível de $10^{5}$ células/m1 e tncubadas a $28^{\circ} 0$ sob agitação, durante 20 horas. A relação entre ca pqotade do frasco e volume de meio era igual a 5:1. Os cistos, suspengos em mejo de encistamento, eram estocados a $4^{\circ} \mathrm{C}$.

Fricistamento espontâneo podia ser obtido em cultura agitadas que, após atingirem uma densidade de aproximatamente $1 \times 10^{6}$ células/m1, começavam a encistar assirucrônicamente.

\section{Germinação (Excistamento)}

Os cistos eram centrifugados e lavados três vezes com meio de crescimento (1000xg, 10 min.); sob condições assépticas. Os cistos lavados, eram, então, inoculados ao nível de $5 \times 10^{3}$ organismos/ml, em meio de crescimento, e cultivados sob agitaçăo a $28^{\circ} \mathrm{C}$. A germinação era acompanhada durante 8 horas, retirando-se alíquotas (intervalos de $30 \mathrm{~min}$ ), que eram observadas ao microscópio de fase para verificação do aparedimento de amebas livres no meio.

\section{Isolamento de núcleos de trofozoitos}

Vários métodos para purificaçăo de núoleos, utilizando meios aquosos de homogenização, foram testados. Segue-se uma descrição sucinta de oata método:

a) Método de Chauveau et al. (1956): o procedimento adotado era semelhante ao descrito originalmente para filgado de rato.

b) Método que emprega o detergente Nonidet P-40: as células eram sedimentadas e lavadas com sacarose $0,25 \mathrm{M} ; \mathrm{CaCl}_{2} 3 \mathrm{mM}$ e Tris-HCl 0,05 M, pH 7,4. Em seguida, as células eram suspensas na mesma solução contenjo letergente e agitadas em agitador magnético por 10 a 30 mınutos a $4^{\circ} \mathrm{C}$. Foram testadas várias cancentra- 
çôes do detergente, variando de 0,5 a 5,0\%。

c) Método de Stevenson (1967), modificado: a 1ise celular era obtida por suspensăo das células em meios hipotônicos ( $\mathrm{NaCl} 0,05 \mathrm{M}, \mathrm{CaCl}_{2} 1 \mathrm{mM}$ ), contendo $0,1 \%(\mathrm{v} / \mathrm{v})$ de Tween 80 .

d) Homogenização de células em um aparelho Virtis, modelo 45: Foram testados diferentes meios de homogenização, contenđo ou não detergentes e vários tempos e velocidades de agitação.

e) Rompimento de células por ultra-som: células lavadas e susperisas em sacarose $0,25 \mathrm{M}$, contendo $\mathrm{CaCl}_{2}$ $3 \mathrm{mM}$ e Tris-HC1 0,05 M, pH 7,4, eram submetidas a diferentes tempos e intensidades de sonicação em um aparelho modelo W185D da Heat-Systems Ultrasonics, Inc.

f) Método de Schneider e Hogeboom (1950), modificado: cerca de $3 \times 10^{8}$ células eram centrifugadas ( 800 $\mathrm{xg}, 10 \mathrm{~min}$.$) e lavadas com sacarose 0,25 \mathrm{M} ; \mathrm{MgCl}_{2} 1 \mathrm{mM}$ : suspensas em $0,5 \mathrm{ml}$ de 3 acarose $0,88 \mathrm{M} ; \mathrm{MgCl}_{2} \mathrm{lmM}_{2}$ e forçadas através de uma agulha hipodérmica 25-8, por 20 vezes. O precipitado obtido por centrifugação do homogenato a $800 \mathrm{xg}$, durante 10 minutos, era lavado duas vezes com a sacarose mais concentrada e suspenso em $1 \mathrm{ml}$ da mesma solução. A fração nuclear ímpura era colocada sobre $10 \mathrm{ml}$ de sacarose 2,4 M, contendo $\mathrm{MgCl}_{2}$ lmM e centrifugada a $28000 \mathrm{rpm}$ no rotor $50 \mathrm{Ti}$ da ultracentrifuga Spinco, durante 1 hora.

g) Método de Hymer e Kuff (1966), modificado: a modificação introduzida refere-se à homogenizaçãc que era obtida por passagem em agulha hipodérmica 25-8, em vez de empregar um homogenizador tipo Potter-Elvejenem.

h) Método de Blobel e Potter (1966), modificado: o precipitado de nixcleos impuros era obtido pelo méto do (f). A purificaçáo posterior dos núcleos era feita conforme descrito por Blobel e Potter (1966)。

i) Método de Rozijn e Tonino (1964): o método foi testado sem nenhuma modificação considerável.

j) Método adotado rotineiramente (Marzzoco e Colli, 1974):

Os núcieos eram sempre isolados de células em crescimento exponencial. Todas as etapas do iso- 
lamento eram realizadas entre 0 \& 1 \% Cerca de $3 \times 10^{8}$ células eram coletadas por centrifrugaça (800xg, $10 \mathrm{~min}$.) e lavadas com NaC1 0,.24 M. Fm seguida, determinava-se o peso úmido de células. As células eram suspensas em $1 \mathrm{ml}$ de uma soluçäo (meio PVP), com a seguinte composição: polivinilpirrolidone 8\%; $\mathrm{MgCl}_{2} \mathrm{ImM} ; \mathrm{CaCl}_{2} 2 \mathrm{mM} ; \mathrm{KCl} 2 \mathrm{mM}$ e TrisHC1 0,05 M, pH '7,4.

As células eram rompidas por passagem em seringa com agulha hipodérmica no 25-8, por 15 a 20 vezes. O homogenato era diluído com meio PVP contendo sacarose $0,6 \mathrm{M}$, até concentração final de $25 \%$ (peso úmido iricial/volume). O homogentto diluído era centrifugado a $700 \mathrm{xg}$ por 10 minutos. O precipitado obtido erai suspenso em um volume conhecido de meio PVP-sacarose $0,6 \mathrm{M}$ 。

A purificação dos núcleos era obtida por centrifugação em gradientes descontínuos de meio PVP, contendo diferentes concentrações de.sacarose. Os gradientes tinham a seguinte composição do topo ao fundo: $0,3 \mathrm{ml}$ de sacarose $1,2 \mathrm{M} ; 0,7 \mathrm{ml}$ de sacarose $1,5 \mathrm{M} ; 0,7 \mathrm{ml}$ de sacarose 1,8 $\mathrm{M}$ e 2,1 $\mathrm{ml}$ de sacarose 2,O M. A amostra $(0,7 \mathrm{ml})$, contendo os núcleos era cuidadosamente coloca da no topo do gradiente e centrifugada no rotor SW 65-Ti da ultracentrifuga Spinco L3, a 50000xg, por 1 hora $x$ $4^{\circ} \mathrm{C}$. Para volumes maiores, utilizava-se o rotor SW 25.1, mantendo as mesmas proporções relativas de soluções de sacarose. Depois da centrifugação, o material se distribuia em três bandas sobrenadantes constituídas por fragmentos de membranas de tamanho variado e um precipitado que continha os núcleos.

Os núcleos eram suspensos em meio PVP-sacarose $0,6 \mathrm{M}$, centrifugados a $700 \mathrm{xg}$ por 10 minutos $\epsilon$ finalmente ressuspensos na mesma solução。

\section{Controle da pureza das preparações de núcleos}

a) Microscopia de fase: os núcleos isoladoș eram rotineiramente analisados, ao mlcroscópio de fase, 
quanto à sua integridare morfológica e ausência de células inteiras ou fragmentos de membranas contaminantes.o número de núcleos e células inteiras era determinado por contropem en câmara de Neuhaler. Fara isso, as preparações eram corartas com uma solução de Giemsa $10 \%$ em sacarose $0,25 \mathrm{M} ; \mathrm{MgCl}_{2} 1 \mathrm{mM}$.

b) Microscopia eletrônica: os precipitados de núcleos eram fixdos, durante 48 horas, em g.lutaral deído 1,5\%, em tampão fosfato de sódio o,?2 M, pH 7,2. Os fragmentos eram, então, transferidos para uma solução de $\mathrm{OsO}_{4} 1 \%$ e, em seguida para uma solução de acetato de uranila $0,5 \%$, onde permaneciam por 3 e 12 horas respecili vamento. A desidratação era conduzida atravếs de uma série gradativa de soluções de etanol. Os núclens rixados e desidratados eram embehidos em Araldite e cortados em um ultra-micrótomo Porter-Blum MT-1. Aa secções ohtidas, com cerca de $90 \mathrm{~nm}$ de espessura, eram coradas em acetato de uranila $2 \%$ e citrato de chumbo $2,6 \%$ e examinatas em um microscópio e]etrônico Zeiss EM9 $5-2$.

\section{Dosagem de RNA, DNA e proteína em nú- cleos e homogenato.}

A composição quimica de núcleos e homogenatos, era analisada através do método de Schmidt-Thannhau ser, conforme descrito por Munro e Fleck (1966). Segue se uma descrição sucinta do procedimento adotado para - fracionamento das preparações de núcleos e homogenatos.

Amostras triplicatas eram precipitadas no ge 1o, durante. $20 \mathrm{~min}$., com concentração final de PGA igua1 a 0,4 N. 0 precipitado obtido por centrifugação a. $10000 \mathrm{xg}, 10 \mathrm{~min}$, era lavado duas vezes com P.CA $0,4 \mathrm{~N}$. o material ácido-insolúvel era suspenso em $\mathrm{NaOH} 0,33 \mathrm{~N}$ e-incubado durante 1 hora a $37^{\circ} \mathrm{C}$. O digesto alcalino era acidificado com PCA (concentração final de $0,4 \mathrm{~N}$ ) e mantido no gelo por 20 min. O precipitado obtido por centrifugação (10000xg, $10 \mathrm{~min}$ ), era lavado com PCA 0,4 N. 
RNA era dosado no sobrenadante e DNA no precipitado.

o precipitado obtido por acidif'icação do digesto alcalino era dissolvido em $\mathrm{NaOH} 0,33 \mathrm{~N}$, a $37^{\circ} \mathrm{C}$, por 20 min. e dosado quanto ao teor de DNA, segundo o método de Ceriotti (1952). O padrão utilizado era 2-desoxi-D-ribose.

RNA era dosado no digesto alcalino com o reagente de orcino1 (Dische, 1955), empregando D-ribose como padrão.

A dosagem de proteína era feita nas preparações de núcleos e homogenatos não fracionados, de acordo com o procedimento de Lowry et al。 (1951). AIbumina sérica bovina era empregada como padrão nas determinações.

7. Ensaio da atividade de RNA polimerase (E.C.2.7.7.6)

Os núcleos utilizados para a determinação da atividade de RNA polimerase, forem lavados por centrifugação ( $800 \mathrm{xg}, 10 \mathrm{~min}$ ) e suspensos em sacarose $0,25 \mathrm{M} ; \mathrm{MgCl}_{2} 1 \mathrm{mM}$ e Tris-HCl $10 \mathrm{mM}, \mathrm{pH} \mathrm{7,4.}$

A mistura de incubação para o ensaio enzimático tinha a seguinte composição: $10 \mu \mathrm{Ci} / \mathrm{ml}$ de $3_{\mathrm{H}-\mathrm{UTP}}(1 \mathrm{l}, 7 \mathrm{Ci} / \mathrm{mM}) ; \mathrm{ATP} 1 \mathrm{mM} ; \mathrm{GTP} 0,4 \mathrm{mM} ; \mathrm{CTP} 0 ; 4 \mathrm{mM}$; DTT $4 \cdot \mathrm{mM} ; \mathrm{KCl} .20 \mathrm{mM} ; \mathrm{MgCl}_{2} 4 \mathrm{mM} ; \mathrm{NaF} 4 \mathrm{mM}$ e Tris $-\mathrm{HCl}$ $0,1 \mathrm{M}, \mathrm{pH} \mathrm{7,6。}$

A reação era iniciada pela adição de uma alị́quota da suspensão de núcleos contendo $15 \mu \mathrm{g}$ de DNA. A incubação era feita a $30^{\circ} \mathrm{C}$, sob agitação. A reação era paralizada por adição de 10 volumes de pirofosfa-to de sódio em TCA $20 \%$ e $200 \mu$ de albumina para facilitar a precipitação, obtida por manutenção dos tubos durante $45 \mathrm{~min}$. no gelo. Os precipitados recolhidos por centrifugação a $10000 \mathrm{xg}$, por 15 min., eram lavados com pirofosfato de sódio 0,05 M em TCA 10\% e depois com etanol 95\%, contendo acetato de sódio 1\%. Os precipitados eram hidrolizados com $\mathrm{KOH} 0,3 \mathrm{~N}$ por 1 hora a $37^{\circ} \mathrm{C}$. O hidrolizado era acidificado com 'TCA até 
concentração final de 10\% e centrifugado ( $10000 \mathrm{xg}, 10$ min.). A radioatividade incorporada em RNA era determinada no sobrenadante, constituído pelo material ácido-insolúvel, e sensível à hidrólise alcalina. 0 procedimento adotado reduz a radioatividade "background" a cerca de $4,5 \%$ da radioatividade incorporada em $\mathrm{RNA}$, após 30 minutos de incubação. Alíquotas $(50 \mu 1)$ do șobrenadante eram colocadas sobre filtros Whatman GF/A, que eram secos e contados em frascos cantendo $10 \mathrm{ml}$ de líquido de cintilação, contendo: hidroxil-hiamina $0,5 \%$ $(\mathrm{v} / \mathrm{v}) ; 4 \mathrm{~g} / 1$ de PPO; $100 \mathrm{mg} / 1$ de POPOP e tolueno q.s.p. A radioatividade era determinada em um cintilador Beck man IS-250, com eficiência de contagem de aproximada mente $37 \%$.

Paralelamente, a atividade de RNA polimerase dos núcleos isolados, foi analisada em presença de actinomicina $D$ e rifampicina, ao nível de $8 \mu \mathrm{g}$ por ml da mistura de incubação.

\section{Purifiçação de mitocôndrias}

Todas as operações eram realizadas entre o e $4^{\circ} \mathrm{C}$. Gélulas em fase exponencial de crescimento, eram sedimentadas e lavadas com sacarose $0 ; 24 \mathrm{M} ; \mathrm{MgCl}_{2}$ $10 \mathrm{mM}$; KCl $10 \mathrm{mM}$ e Tris-HCl $10 \mathrm{mM}, \mathrm{pH} \mathrm{7,4} \mathrm{por} \mathrm{centri-}$ fugação a $1000 \mathrm{xg}$ durante $10 \mathrm{~min}$. As células, suspensas em três volumes da mesma sacarose, contendo EDTA $5 \mathrm{mM}$ em vez de $\mathrm{MgCl}_{2} 10 \mathrm{mM}$, eram homogenizadas en um homogenizador tipo Dounce (10 movimentos). A extensão do rompimento oelular era acompanhada ao microscópio de fase. O homogenato era centrifugado 10 minutos a 900xg e o sobrenadante obtido era centrifugado a $10000 x g$ por 20 min. Os precipitados compactos obtidus eram submetidos a dois ciclos adicionais de centrifuga ção diferencial. A suspensão final de mitocôndrias, ao microscópio de fase, não apresentava núcleos ou células inteiras. A mesma contatação era feita ao microscó pio eletrônico onde, todavia, era possivel verificar a presença de fragmentos de membranas contaminantes. 


\section{Extração de DNA}

O método descrito a segrair era utilizado, com as devidas adaptações, para extrair DNA celular total, nuclear e mitocondrial de trofozoitos e DNA total de cistos.

Todas as operações eram realizadas entre 0 e $4^{\circ} \mathrm{C}$. A preparação em questão era lavada com NaCl $0,14 \mathrm{M}$, por centrifugação. O material centrifugado era pesado e suspenso em um meio de extração contendo dietilditiocarbamato de sódio $0,3 \mathrm{M}$ e fenolftaleína difosfato $0,015 \mathrm{M}, \mathrm{pH} 7,5$, na proporção de $8: 1(\mathrm{v} / \mathrm{w})$. Adicionava-se SDS até concentração final de $2,5 \%(w / v)$ a a suspensão era homogenizada manualmente em um homogenizador tipo Potter-Elvejehem. O lisado era extraído com igral volume de uma mistura contendo 3 partes de fenol e 1 parte de meio de extração ( $/ \mathrm{v}$ ) durante 30 min. à temperatura ambiente. As soluções de fenol e meio de extração eram preparadas imediatamente antes de usar. Após a extração fenólica, a emulsão era centrifugada ( $10000 \mathrm{xg}, 15 \mathrm{~min}$.) e a fase aquosa, extremamente viscosa, era removida e precipitada com 2 volumes de etanol. O precipitado fibroso, contendo os ácldos nucleicos era coletado com a ajuda de um bastão de vidro em rotação. Os ácidos nucleicos eram dissolvidos.em SSC, num volume igual ao da fase aquosa da extração com fenol e incubados a $37^{\circ} \mathrm{O}$ com RNase pan creática ( $150 \mu \mathrm{g} / \mathrm{ml}, 1$ hora) e pronase (500 $\mathrm{gg} / \mathrm{ml}, 3$ horas), ambas prèviamente aquecidas a $80^{\circ} \mathrm{O}$ por $15 \mathrm{mi}-$ nutos. Adioionalmente, o DNA era tratado com $\alpha$-amila se $\left(200 \mu \mathrm{g} / \mathrm{ml}, 2 \mathrm{~h}\right.$. a $\left.37^{\circ} \mathrm{C}\right)$, prèviamente analisada quanto à contaminação por DNase. Seguia-se nova desproteinização, agora com fenol $88 \%(\mathrm{v} / \mathrm{v})$, contendo $0,1 \%$ de hidroxi-quinolina. A fase aquosa era precipitada com 2 volumes de etanol. O DNA obtido ere dissolvido em $0,1 \mathrm{SSC}$ e precipitado com isopropanol, conforme descrito por Marmur (1961), Finalmente, o DNA era aubmetido a extensa diálise contra $0,1 \mathbf{8 S O}$ 
10. Centrifugacão em gradientes de CsCl

ヌ) Centrifugação preparativa

As preparações de DNA eram adicionalmente purificadas ou fracionadas em diferentes componentes, por centrifugação em gradientes de CsCl. 0 procedimento adotado era o seguinte: CsCl sóliło era adicionado a $3,5 \mathrm{ml}$ de solução de DNA contendo 1 a 20 unidades de absorbância (260 nm) em 0, 1 SSC ou Tris$\mathrm{HCl} 0,01 \mathrm{M}$, até ser obtida uma densidade inicial de $1,725 \mathrm{~g} / \mathrm{cm}^{3}$. A densidade da solução era determinada a partir do índice de refração (Ifft, et al。, 1961). A solução era distribuída em tubos de nitrocelulose, preenchidos com óleo mineral (Sigma). A centrifugaçãc era feita no rotor $\mathrm{SW} 50.1$ da ultracentrífuga spinco $\mathrm{L}-3$, a $38000 \mathrm{rpm}$ e $25^{\circ} \mathrm{C}$. Cerca de 40 frações com 8 gotas cada uma, eram recolhidas por punção no fundo do tubo, convenientemente diluídas com tampão e analisadas quanto à absorbância a 260nm. A linearidade do gradiente era verificada através do Índice de refração das frações não diluídas. As frações com alta absorbância eram reunidas e dializadas contra o mesmo tampão. O DNA era coletado por centrifugação no rotor $50 \mathrm{Ti}$ da Spinco I-3, a $40000 \mathrm{rpm}, 4^{\circ} \mathrm{C}$, durante cerca de 20 horas.

Em alguns experimentos, as frações dos gradientes eram analisadas quanto ao teor de hexoses e desoxirribose, determinado segundo os metodos descritos por Mockrash (1954) e Giles e Myers ( 1965 ), respectivamente. Os padrões utilizados nas dosagens eram D-glicose e 2-desoxi-D-ribose.

b) Centrifugação analítica (determinação da clensidade de flutuação)

As soluções de DNA eram prèviamente dializadas contra $\mathrm{NaCl}$ O,Ol M e centrifugadas a $8000 \mathrm{xg}$ durante 45 minutos.

Amostras de DNA contendo cerca de $3 \mu \mathrm{g}$, 
eram centrifugadas a $44000 \mathrm{rpm}$, durante 21 horas a $25^{\circ} \mathrm{C}$, em gradiente de $\mathrm{CsCl}$ ( $\rho$ inicial $=1,700 \mathrm{~g} / \mathrm{cm}^{3}$ ), contendo DNA do fago $2 \mathrm{C}$ de Bacilus subtilis $(\rho=1,742$ $\mathrm{g} / \mathrm{cm}^{3}$ ) como padrão de densidade. As análises eram realizadas em uma ultracentrífuga Spinco, modelo $\mathrm{E}$, equipada com um sistema padronizado para a medida da absorção no ultravioleta, um monocromador e um "scanner" ele trônico. A densidade de flutuação era calculada segundo Vinograd e:Hearst (1962), a partir da densidade de referência $\left(1,742 \mathrm{~g} / \mathrm{cm}^{3}\right)$ e expressa em termos da densidade inicial da solução, à pressão atmosférica.

\section{Fragmentação de DNA}

Para a obtenção de fragmentos de DNA de baixo peso holecular, utilizava-se um Omni-Mixer da Sorvall Inc., equipado com um "micro-attachment", operando a $0^{\circ} \mathrm{C}$. Cerca de $3 \mathrm{ml}$ de solução contendo $100 \mu \mathrm{g}$ de DiNA/ml, eram agitados durante 30 minutos, com o dial na posição 8 .

\section{Avaliação de peso molecular}

a) DNA nativo

O peso molecular (PM) era avaliado a partir da velocidade de sedimentação, determinada por centrifugação zonal em gradientes lineares de sacarose. 0 padrão de PM utilizado era o DNA do fago $\mathrm{T}_{7}$, marcado com ${ }^{32} \mathrm{P}$.

As amostras de DNA eram euidadosamente colocadas sobre $25 \mathrm{ml}$ de um gradiente de sacarose 5 a 20\%, contendo NaCl $1 \mathrm{M}$; EDTA $1 \mathrm{mM}$ e Tris-HCl $10 \mathrm{mM}, \mathrm{pH}$ 7,8 (gradiente neutrd) ou $\mathrm{NaCl} 0,9 \cdot \mathrm{M}$; EDTA $1 \mathrm{mM} \quad \mathrm{e}$ $\mathrm{NaOH}$ 0,1 M (gradiente alcalino) e centrifugadas a $18000 \mathrm{rpm}$ no rotor SW 25.1 (Spinco L-3), por 16 horas a $4^{\circ} \mathrm{C}$. Frações de aproximadamente $1 \mathrm{ml}$ eram coletadas a partir do fundo do tubo e analisadas quanto à absorbância a $260 \mathrm{~nm}$ e radioatividade. A radioatividade era determinada por cintilação líquida na solução descrita 
por Bray (1960), em um cintilador Beckman IS-250。

O PM do DNA nativo (gradientes meutros) era determinado conforme sugerido por Burgi e Hershey (1963) e o PM do DNA monocatenário (gradientes alcalinos), através da equação proposta por studier (1965)。

b) DNA fragmentado

O peso molecular de DNA fragmentado conforme descrito no item 11, era avaliado a partir da velocidade de sedimentéção em gradientes lineares de sacarose 5 a 20\% em SSC. O DNA era desnaturado com álcali, neutralizado e centrifugado no rotor $\mathrm{SW} 50.1$ (Spinco), a $45000 \mathrm{rpm}$, durante 4 horas a $4^{\circ} \mathrm{C}$.

O DNA utilizado como referência era o DNA do fago fd (circular, monocatenário), que, nas condições utilịadas, comporta-se como uma molécula linear com $\mathrm{S}_{2 \mathrm{O}, \mathrm{w}}^{\mathrm{O}}=24,4 \mathrm{~S}$ (Colli et al., 1971). As constantes de sedimentação obtidas eram relacionadas aos pesos moleculares dos DNAs, através da equação proposta por Eigner e Doty (1965).

O procedimento empregado para a fragmentação de DNA produzia sempre uma população homogênea de moléculas, conforme sugerido pelos perfis de absorbância dos gradientes de sacarose, caracterizados por uma distribuição unimodal e gaussiana.

\section{3) Renaturação de DNA}

A renaturação de DNA era medida pela queda de absorbância a 260nm (Wetmur e Davidson,1968), determinada em um espectrofotômetro Zeiss PMQ II. A temperatura das soluções de DNA, contidas em cubetas de quartzo com tampa de tẹflon, era mantida constante por circulação de água proveniente de um banho Colora (NB-36252, Germany), termostatizado a $60^{\circ} \mathrm{C}$. As amostras de DNA em NaCl 1 M, eram desnaturadas por adi ção de 0,05 partes de $\mathrm{NaOH} I \mathrm{~N}$ e, depois de $15 \mathrm{~min}$. neutralizadas som igual volume de $\mathrm{NaH}_{2} \mathrm{PO}_{4}$ 2M. As so- 
luções utilizadas para a desnaturação e neutralização eram mantidas a $60^{\circ} \mathrm{C}$ e adicionadas ao DNA contido na cubeta do espectrofotômetro com o auxilio de uma serin ga termostatizada.

As experiências de renaturação empregavam sempre, preparações de INA fragmentado conforme descri to no item 11. A tabela 6 (Resultados) mostra os valores de PM de algumas preparações de DNA.

\title{
14. Curvas de desnaturação térmica (Determinação de $\mathrm{T}_{\mathrm{m}}$ )
}

\begin{abstract}
A determinação de $\mathrm{T}_{\mathrm{m}}$ foi realizada de acordo com o método de Mandel e Marmur (1968), utilizan do o mesmo equipamento descrito para as experiências de renaturação. A temperatura era medida através de um termômetro especialmente adaptado para ficar imerso em uma solução de referência. Os diferentes DNAs estavam dissolvidos em 0,1 SSC e todos os dados eram cor rigidos para expansão térmica.
\end{abstract}




\section{Curvas de Crescimento}

O crescimento foi testado em dois mèios Je cultura ( $A$ e B), sob diferentes condições de aeração (culturas agitadas e estacionárias). A figura 1 mos tra os resultados obtidos. O crescimento em meio A é ligeiramente mais acentuado, tanto em culturas estacionárias, como agitadas. Culturas estacionárias caracterizam-se por crescimento máximo de cerca de $4 \times 10^{5}$ células/ml, atingido em torno do 18ㅇ dia de cultivo. Nessa ocasião, a maioria dos organismos apresenta forma esférica e há baixa porcentagem de cistos. Nas culturas agitadas, a fase logarítmica é mais longa, o número máximo de células/ml é maior $\left(2-7 \times 10^{6}\right)$ e, a partir do 80 dia de cultivo, inicia-se o encistamento em massa das amebas. O nível de células presentes na fase estacionária é maior em culturas agitadas crescendo em tubos inclinades (maior aeração), do que em erlenmeyers. Conforme verifjcado por outros autores (Byers et al., 1969), o crescimento parece ser determinado pela quantidade de oxigênio dissolvido no meio.

As curvas de crescimento determinadas por contagem do número de células por ml de meio de cultura (Figura la) apresentam uma fase de crescimento exponencial e uma fase estacionária. A aparente fase de "lag"verificada quando o crescimento é medido por absorbância da cultura a 600nm (Figura 1A), pode ser explicada pela relação não linear existente entre absorbân cia e no de células/ml (Iabela 1 j.

Para a obtenção de grandes quantidadeg de células, adotou-se, rotineiramente, a utilização de fermentador. Nessas condições, as curvas de crescimento obtidas são semelhantes às curvas de culturas agitadas em erlenmeyers, mostradas na Figura la. 

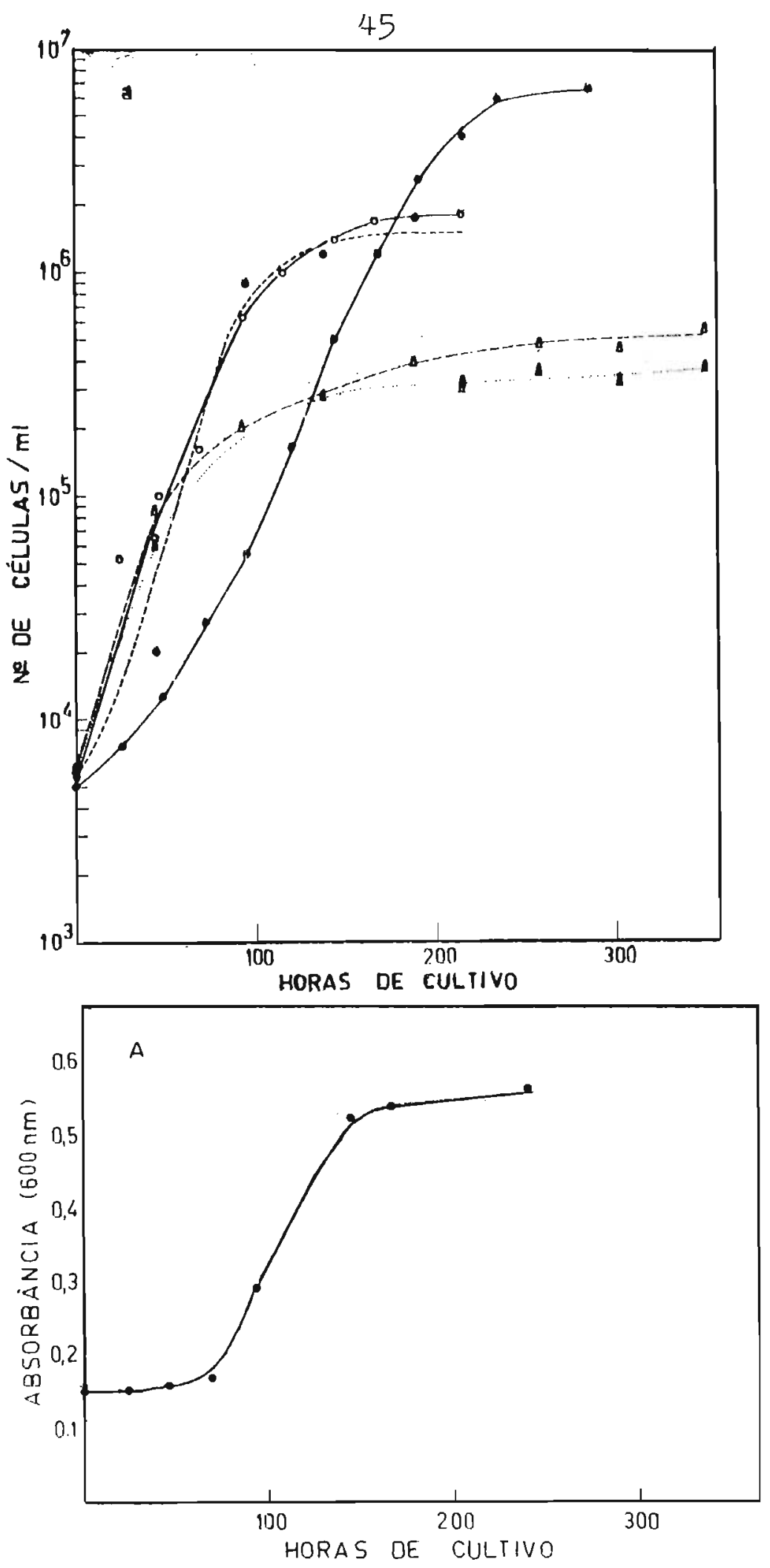

Figura I - Crescimento de A. castellanii em diferentes condições de cultura, o crescimento foi medido por contagem do número de células por ml em cấmara de Neubauer (gráfico a) ou por determinação da absorbância a 600 nm (gráfico A). Os resultados são a média de duas experiências. No gráfico a, os círculos e triângulos indicam, respectivamente, o crescimento de culturas agitadas e estacionárias em erlenmeyers.0 crescimento foi determinado em meio A (símbolos vazios) e tni mejo B (símbolos clieios). Os círculos cheios interrompidos representam uma curva de crescimento em tubos sob agitação, contendo meio B. O gráfico A mostra o crescimento de culturas agitadas em meio $\Lambda$. 
Tabela 1 - Relação entre absorbância a $600 \mathrm{~nm}$ e número de organismos por $\mathrm{ml}$ em culturas de trofozoitos de $\underline{A}$. castellanii

\begin{tabular}{cc}
\hline no de células/ml & $A_{600}$ \\
\hline $1,2 \times 10^{6}$ & 0,245 \\
$4,6 \times 10^{5}$ & 0,155 \\
$2,3 \times 10^{5}$ & 0,125 \\
$1,4 \times 10^{5}$ & 0,120 \\
$5,4 \times 10^{4}$ & 0,115 \\
$3,0 \times 10^{4}$ & 0,115 \\
$2,1 \times 10^{4}$ & 0,115 \\
$3,2 \times 10^{3}$ & 0,115 \\
\hline
\end{tabular}

Os dados foram obtidos com suspensões de células de una cultura em fase logarítmica, diluídas com meio de crescimento estéril (média de três determinações). 0 número de orgarismos/ml foi medido por contagem em câmara de Neubauer; a absorbância foi determinada em um espectrofotômetro Coleman Jr. II.

\section{Encistamento induzido}

Obtinha-se, em média, 96\% de encistamen to, desde que o número de células por ml fôsse iguạ ou inferior a $10^{5}$. Densidade maior de células impedia o encistamento. Os cistos obtidos eram viáveis, conforme demonstrado pela germinação observada depois de 5 horas de incubação em meio de crescimento. 0 excistamento foi acompanhado ao microscópio de fase, tendo sido possível constatar a saída da ameba por um dos ostíolos da parede do cisto que permanece intacta no final do processo. 


\section{Isolamento de núcleos}

A maior parte dos métodos testados não produzia lise celular adequada. O método de Blobel e Potter (1967) modificado, proporcionava um homogenato contendo baixa porcentagem de células inteiras e núcleos aparentemente íntegros. Todavia, não foi possíve1. obter purificação dos núcleos por ultracentrifugação. A adoção do método descrito por Rozijn e Tonino (1964), sem modificações, produzia homogenato com grande número de células iritactas. 0 procedimento adotado rotineiramente (Marzzoco e Colli, 1974) é uma modificação desse método e permite obter isolamento e purificação de núcleos em espaço de tempo relativa mente curto (90 minutos após homogenização). A homogenização das células por passagem em seringa com agutha hipodérmica, constitui um método eficiente, já que a porcentagem de células intactas na fração nuclear era em torno de 3\%. A fração nuclear impura, resultante da centrifugação em baixa velocidade do homogenato, é altamente purificada por ultracentrifugação em gradientes descontínuos de soluções concentradas de sacarose. A pureza das preparações de núcleos era veri ficada por microscopia óptica e eletrônica. A figura 2 mostra o aspecto da suspensão final de núcleos isolados, onde é possível observar a ausência de células inteiras e fragmentos de membranas. Micrografias eletrônicas (Figura 3), mostram núcleos intactos, envolvidos por um envelope duplo, com ribossomos aderidos à membrana externa. Nucléolos grandes e densos, que são característicos dessa espécie, também podem ser vistos. O grau de preservação estrutural mantido pelos núeleos isolados é constatado por comparação com micrografia de núcleos "in situ", contorme ilustrado na figura 3. Os meios de extração utilizados contêm $8 \%$ de polivinil-pirrolidona, necessária para manter a integridade dos núcleos durante o isolamento (Rozijn e Tonino, 1964). O meio de homogenização contém, adicionalmente, baixa concentração $(0,02 \%)$ do detergente Tri 
ton $\mathrm{X}-100$, que acelera a lise celular e propicia melhor dispersão dos componentes celulares liberados, além de ser um inibidor de DNase (Hymer e Kuff,1966). o rendimento de núcleos é de aproximadamente $80 \%$ conforme avaliado pela recuperação de DNA (Tabela 2).

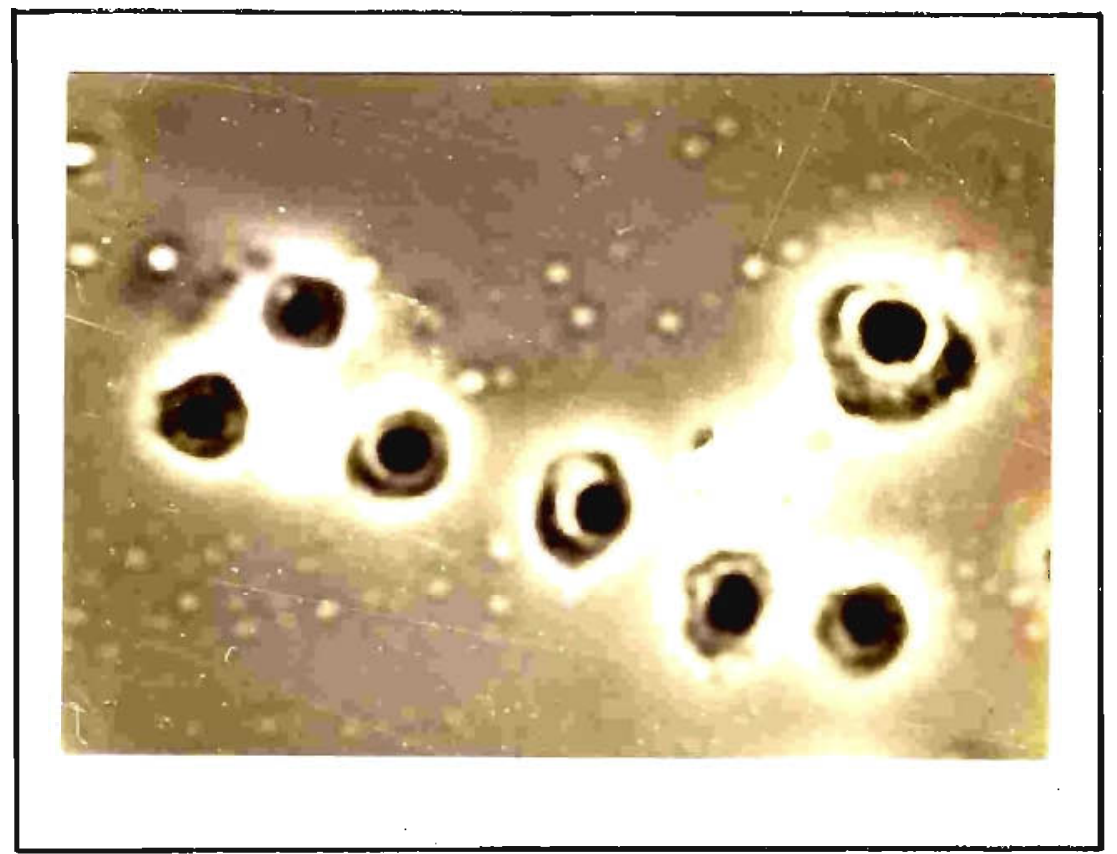

Figura 2 - Aspecto de uma preparação de núcleos de trofozoitos de A. castellanii, suspensoa em meio PVP-sacarose $0,6 \mathrm{M}$ ao microscópio de fase. Os núcleos estão intactos e não se observam célu las inteiras ou fragmentos de membrana. Aumento = 2560 vezes. 


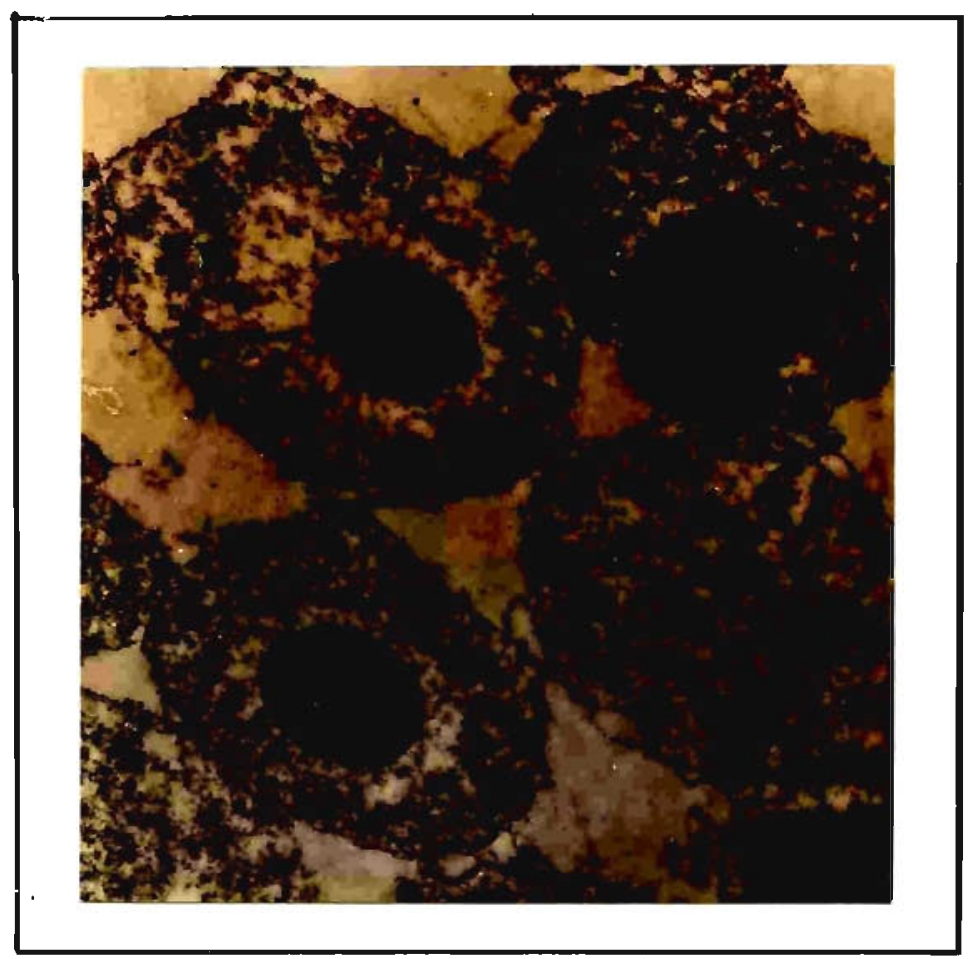

(a)

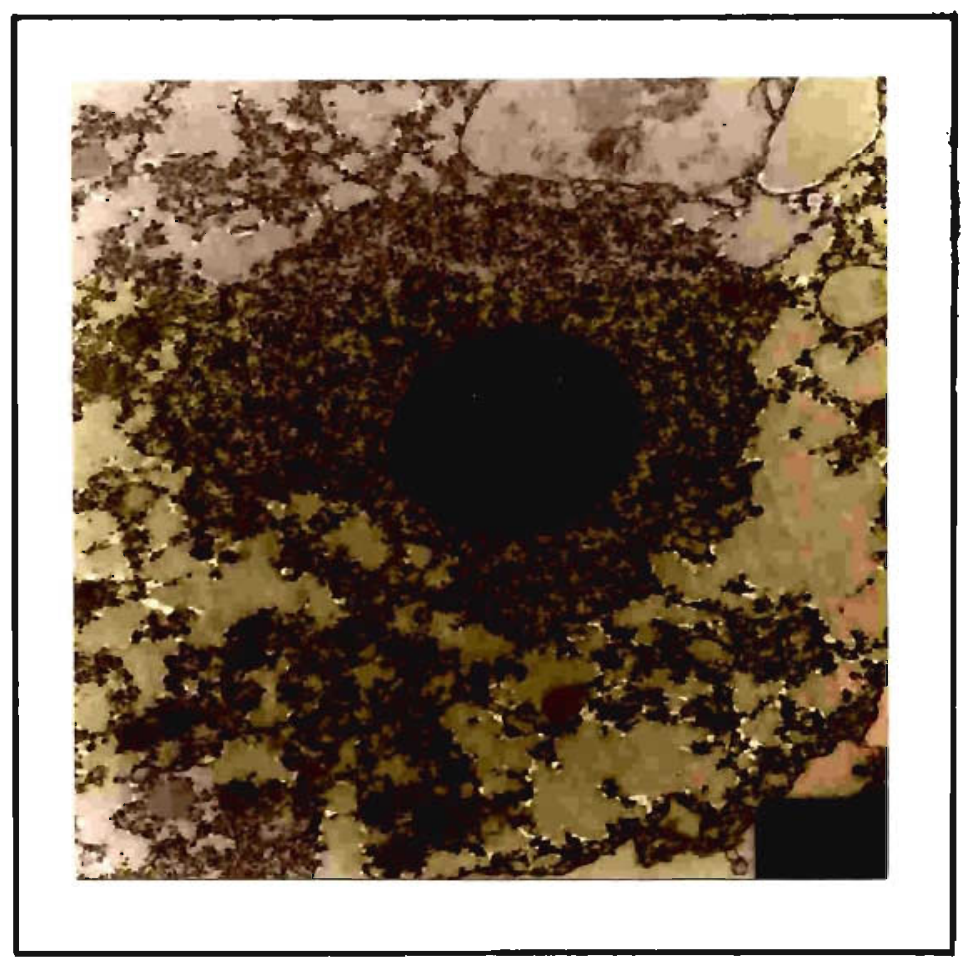

(b)

Figura 3 - Micrografias de núcleos de A. castellanii. A preparação do material para microsco pia eletronica está descrita em Métodos. A foto (a ) mostra o grau de reservação estrutural mantido pelos núcleos isolados, como pode ser observado por comparação com a aparência dos núcleos "in situ", mostrada na foto (b). Os aumentos das fotos (a) e (b) são respecti vamente iguais a 14000 e 10000 vezes. 


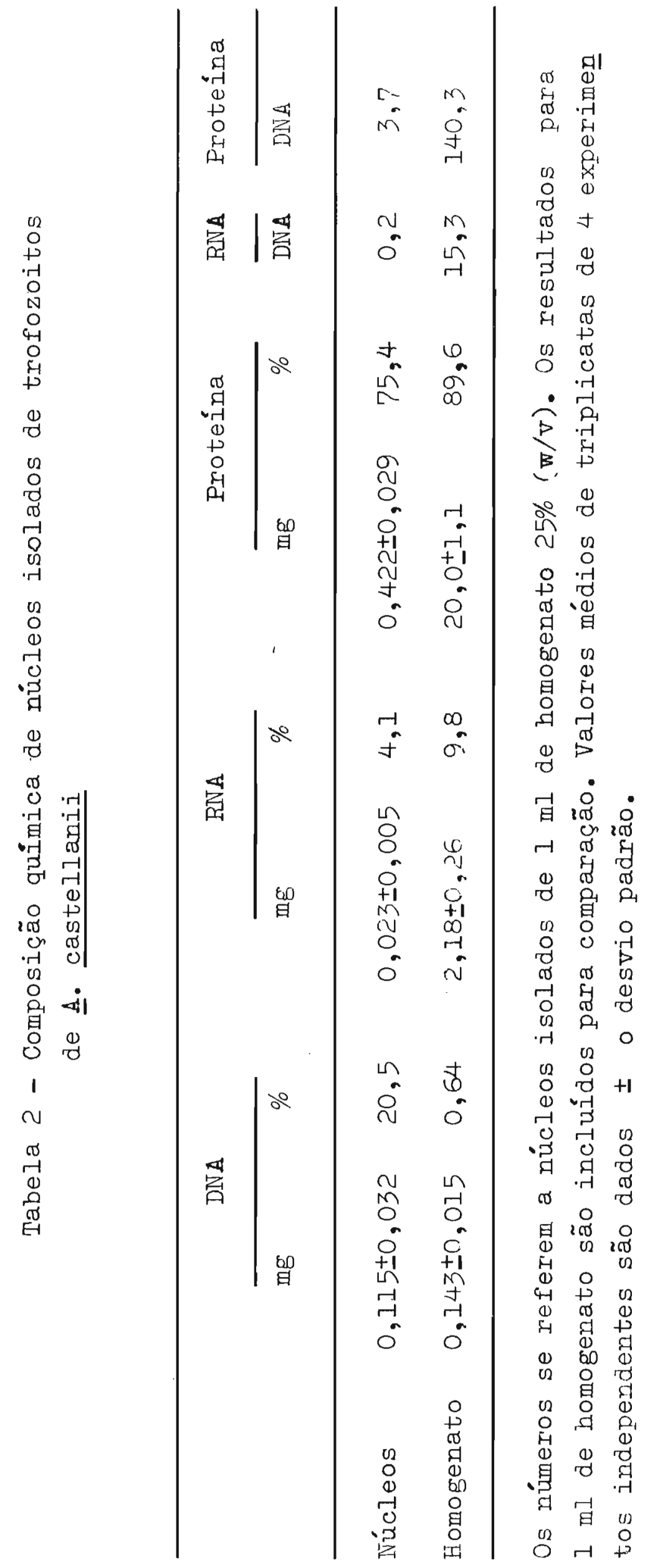




\section{Composição química de núcleos isolados}

A tabela 2 mostra os resultados relativos ao teor de DNA, RNA e proteína, no homogenato e núcleos purificados. Os resultados mostram que $80 \%$ do DNA do homogenato foi recuperado no precipitado de núcleos. As preparações de núcleos utilizadas para o estudo da composição química também foram analisadas quan to ao número de núcleos por $\mathrm{ml}$, através de contagem em câmara de Neubauer ao microscópio de fase. Com esses resultados e os dados da tabela 2, foi possivel avaliar a composição média por núcleo, que era igual a $38 ; 8 ; 2,1$ e 10,6 pg de proteína, RNA e DNA, respectiva mente.

5. Atividade de RNA polimerase(E.C.2.7.7.6) em núcleos isolados

A figura 4 mostra os resultados da cinética da reação catalisdda pela RNA polimerase da fração nuclear. Nas condilções de incubação adotadas, a ve locidade da reaçãc diminui logo após os primeiros $5 \mathrm{mi}$ nutos de incubacão.A velocidade inicial de síntese de RNA nos núcleos isolados, conforme avaliada pela incorporação de UMP em RNA, era igual a 83 picomoles de UMP/ $\mathrm{min} / \mathrm{mg}$ de INA a $30^{\circ} \mathrm{C}$. Essa velocidade, todavia, pode estar um pouco subestimada, já que não foi considerada a possibilidade da existência de um "pool" endógeno de UMP, que poderia influenciar os resultados nas condições de ensaio empregadas. Conforme esperado para uma reação DNA-dependente, a adição de actinomicina $D$, ao nível de $8 \mathrm{\mu g} / \mathrm{ml}$, reduz a incorporação de radioatividade em RNA de cerca de $80 \%$. Por outro lado, rifampicina, conhecido inibidor de sintese de RNA bacteriano ( di Mauro et al., 1969) e mitocondrial (Mukerjee e Goldfe der, 1973), não teve nenhum efeito na enzima nuclear da ameba. Os resultados estão resumidos na tabela 3. 


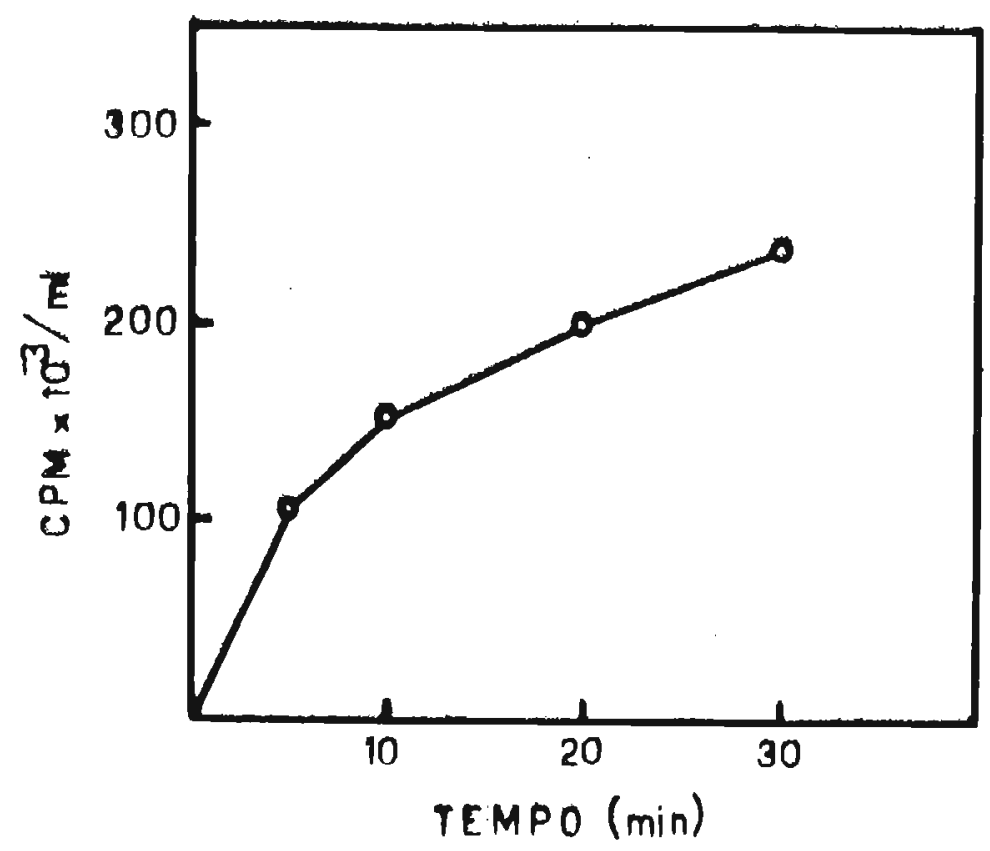

Figura 4 - Cinética de incorporação de UMP- ${ }^{3} \mathrm{H}$ em núcleos isolados de trofozoitos de A. castellanii. A radioatividade TCA precipitável e sensivel à hidrólise alcalina foi determinada conforme descrito em Métodos. 0 no de $\mathrm{cpm} / \mathrm{ml}$ da mistura de incu bação é registrado em função do tempo de reação a $30^{\circ} \mathrm{C}$. 
Tabela 3 - Efeito de antibióticos na reação catalizada pela RNA polimerase de núcleos isolados de A. castellanii.

\begin{tabular}{crc}
\hline Adições & $\begin{array}{c}\text { cpm/mg de DNA } \\
\left(\mathrm{x} 10^{-6}\right)\end{array}$ & $\%$ de inibição \\
\hline- & 5,32 & - \\
actinomicina D & 0,96 & 82 \\
rifampicina & 5,72 & zero \\
\hline
\end{tabular}

Condições de ensaio descritas em Métodos. Resultados obtidos por incubação durante 10 minutos a $30^{\circ} \mathrm{C}$. A concentração de antibióticos testada foi de $8 \mu \mathrm{g} / \mathrm{m} 1$.

\section{Extracão de DNA}

o INA total de trofozoitos, obtido pelo procedimento descrito em Métodos (Marzzoco e Colli, 1974), apresenta espectro de absorção característico, ilustrado na figura 5. Inicialmente, o DNA não era tratado com a-amilase (Adam et al., 1969), fornecendo um espectro de absorção atípico, provàvelmente devido à contaminação por glicogênio, conforme sugerido pela comparação entre o espectro de absorção de DNA não tratado com a-amilase e glicogênio comercial, no ultra violeta (Figura 5). O glicogênio utilizado (Sigma), foi analisado quanto ao teor de hexoses (reação de antro ma), DNA (Reação de difenilamina), RNA (reação de orcinol) e proteína (reaçäo de Folin-Ciocalteau). Os resultador obtidos mostram que a preparação de glicogênio é realmente pura, contendo baixa porcentagem de proteí na $(0,3 \%)$ e ácidos nucleicos (cerca de $0,1 \%$ ) contaminan tes. 


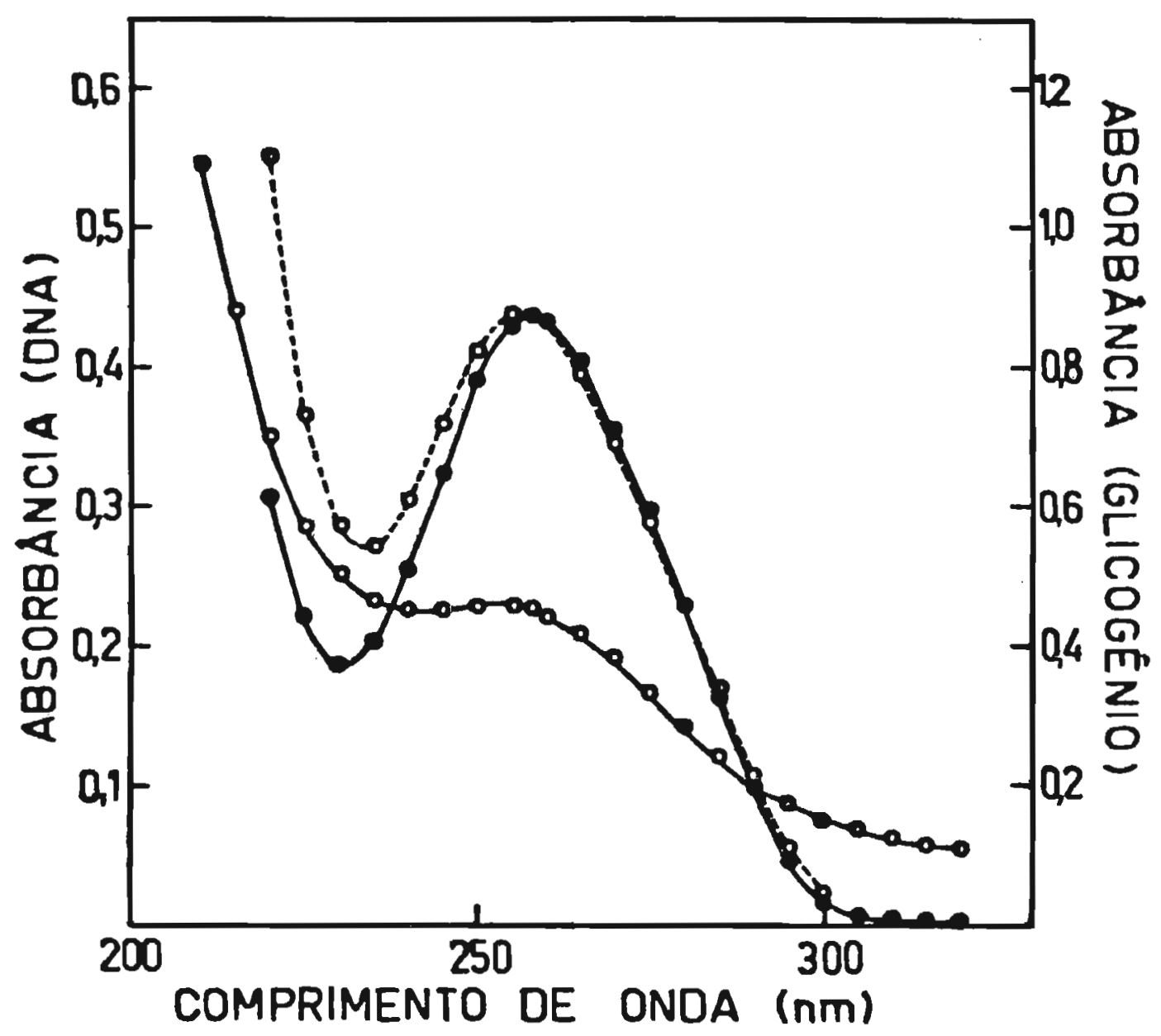

Figura 5 - Espectro de absorção de DNA total de trofozoitos tratado ou não com a-amilase e de glicogênio comercial (Sigma). A concentração de DNA tratado com a-amilase (círculos cheios) e DNA näo tratado (círculos vazios, linha pontilhada), conforme a valiado pela absorbäncia a $260 \mathrm{~nm}$, era igual a $22 \mu \mathrm{g} / \mathrm{ml}$. cheia), determinada por reação com antrona, era igual a $3 \mathrm{mg} / \mathrm{ml}$. As soluções eram feitas em O, ISSC e a absorbância no ultra-violeta medida em um espectrofotômetro Zeiss PMQ II. 
O DNA nuclear também apresentava razões de absorbância típicas: $230 / 260 \mathrm{~nm}=0,435$ e $280 / 260$ $\mathrm{nm}=0,534$.

o peso molecular do DNA nativo, utilizan do-se DNA radioativo do fago $T_{\eta}$ como padrão, variava de 8 a $12 \times 10^{6}$ daltons (gradientes de sacarose neutros). Em gradientes alcalinos, obtinha-se um valor de peso molecular próximo à metade do peso molecular do DNA nativo.

\section{Centrifugação em gradientes de CsC1}

a) DNA total de trofozoitos

A análise do perfil do DNA total de trofozoitos em gradientes de densidade preparativos, sugeria, inicialmente, a presença de dois satéljtes com densidade menor que o componente principal, conforme evidenciado na figura 6B. O satélite menos denso, situava-se na mesma região de densidade que glicogênio comercial (Sigma) (Figura 6A). As frações indicadas pela barra presente na figura $6 B$, foram reunidas e submetidas à centrifugação analitica em gradientes de CsCl. O perfil obtido (Figura 6b), confirma a existência de dois satélites: um com densidade igual a $1,692 \mathrm{~g} / \mathrm{cm}^{3}$ e outro com densidade igual a $1,670 \mathrm{~g} / \mathrm{cm}^{3}$. Esta última banda tem um comportamento anômalo, já que absorve radiação de $320 \mathrm{~nm}$ (Figura 6a). Na tentativa de elucidar a natureza dessa banda, foi feita a dosagem de desoxirribose (reação de difenilamina) e hexoses (reação de antrona), em cada fração de gradien-tes preparativos de DNA total tratado ou não com aamilase. A figura 7 mostra os resultados obtidos. A banda anômala (componente menos denso), não contém DNA (Figura 7A), mas contém grande quantidade de hexoses, de acordo com a reação fortemente positiva com - reggente de antrona. Essa banda é compostia provàvel-m mentie por gilicogênio, porque é sensível à ação de amilase, que elimina o material antrona-positivo (Fi- 

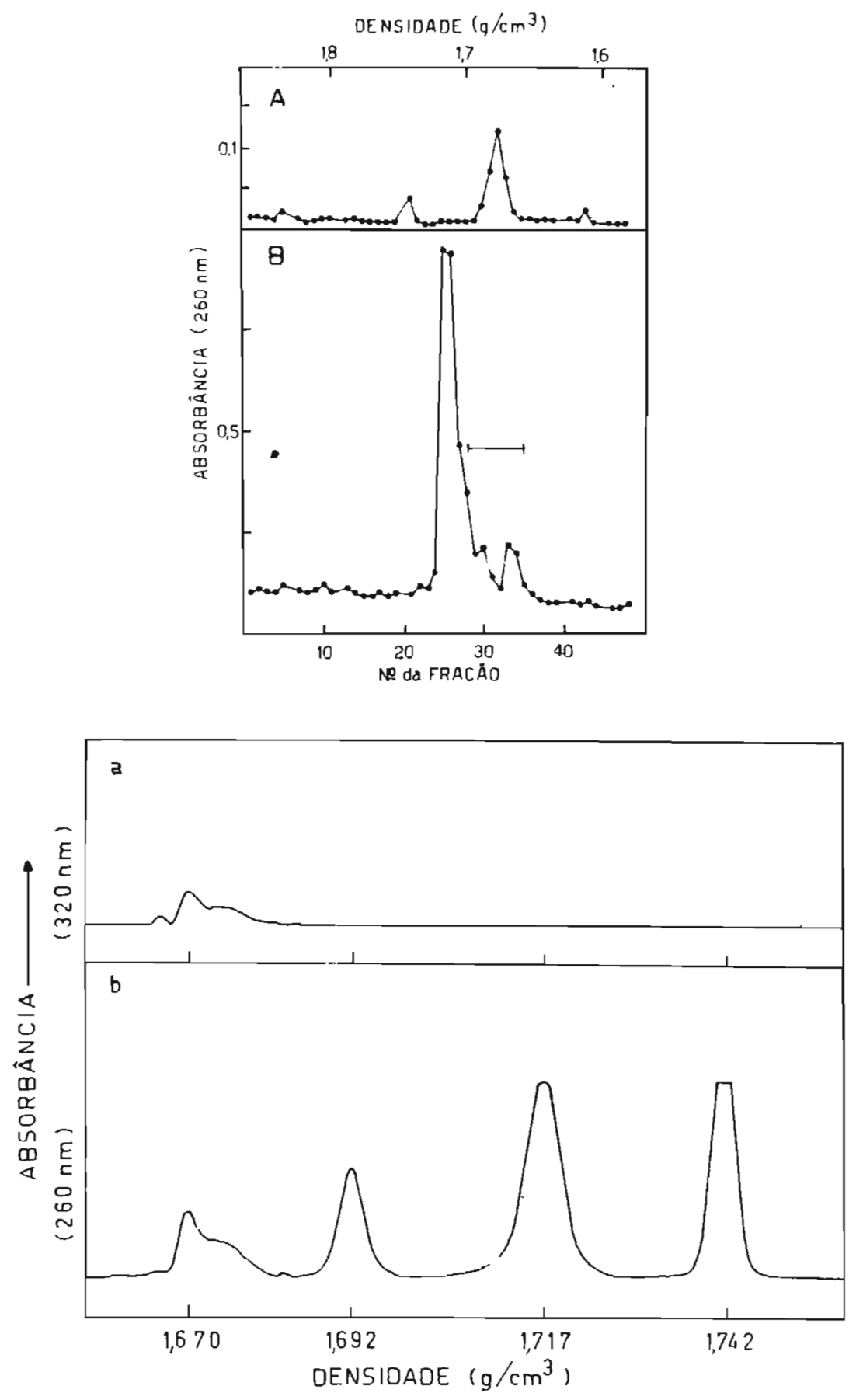

Figura 6 - Perfil de absorbância de DNA to tal de trofozoitos de $\underline{A}$ - castellanii e glicogênio comer cial, após centrifugaçăo em gradientes de CsCl. As figuras A e B mostram os resultados obtidos com gradientes preparativos contendo $2 \mathrm{mg}$ de glicogênio (Sigma) e $146 \mu \mathrm{g}$ de DNA total respectivamente. As figuras a e b mostram o perfil a 320 e $260 \mathrm{~nm}$, obtido por centrifugação analítica das frações do gradientes 3 indicados pela bar ra horizontal que foram reunidas e dializadas contra $\mathrm{N}_{\mathrm{a}} \mathrm{Cl} \mathrm{O}, \mathrm{Ol} \mathrm{M}$. Condições de centrifugação descritas em Métodos. Na figura b, o pico com densidade igual a $1,742 \mathrm{~g} / \mathrm{cm}^{3}$, refere-se ao DNA do fago $2 \mathrm{C}$, utilizado como marcador. 


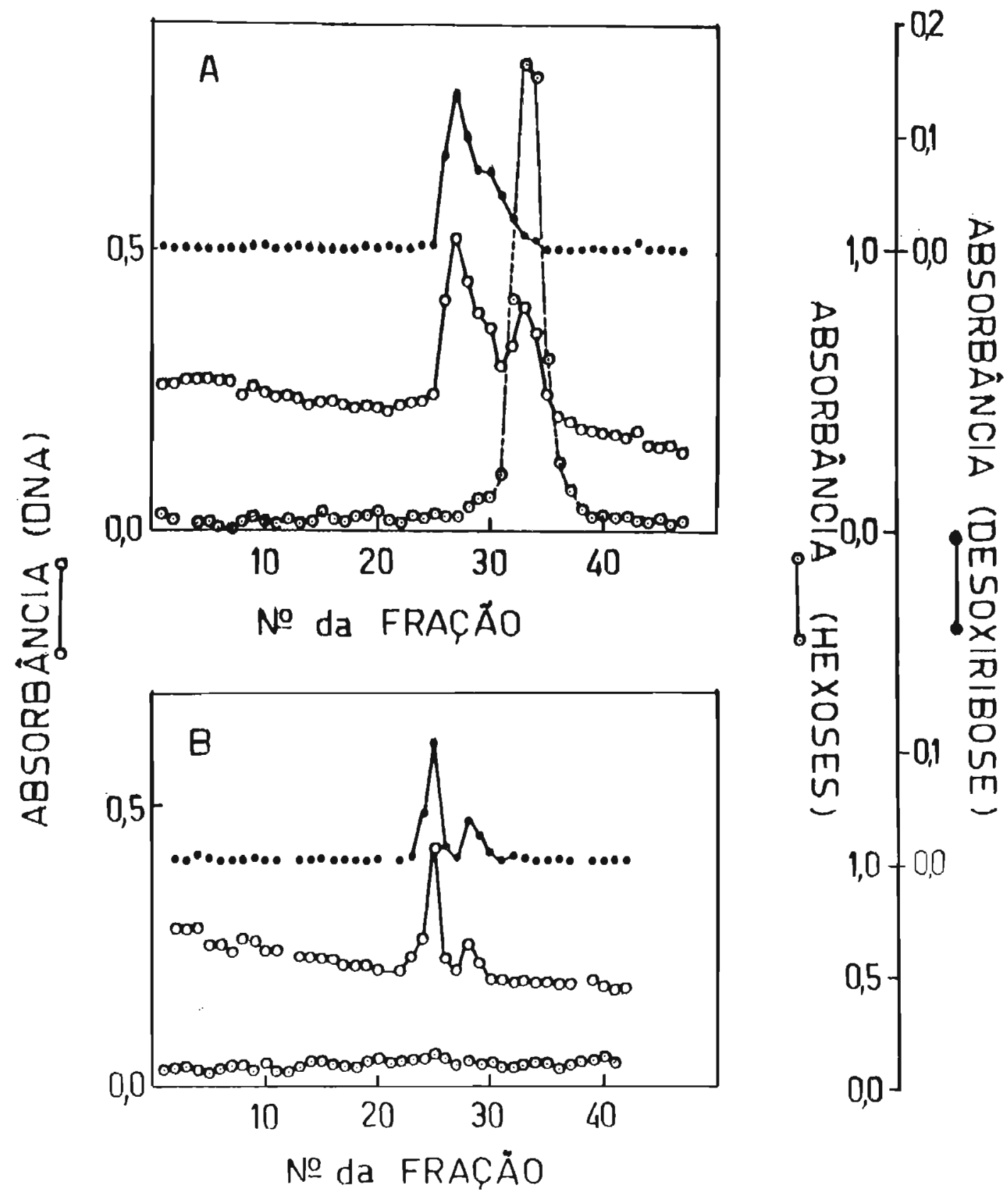

Figura 7 - Centrifugação de DNA total de trofozoitos de A. castellanii em gradiertes de CsCl . As figuras $A$ e $\bar{B}$ mostram os resultados da medida de absorbância a 260nm (círculos cheios), dosagen com difenilamina (círculos vazios) e dosagern com antrona (círculos vazios pontilhados), nas frrações de gradientes contendo DNA total tratado ou não com $\alpha$-amilase respectivamente。Condições de centrifugarão descritas em Métodos. 
gura 7B). As outras duus bandas observadas são realnente constituídas por DNA, conforme evjdenciado pela superposição do perfil de absorbância a 260nm e absurhância de desoxirribose, medida pela reação com difenilami na (Figura 7A e B). Além disso, o tubo do gradiente de CsCl contendo DNA não tratado com $\alpha$-amilase, apresen ta uma banda opalescente que é eliminada por tratamento com $\alpha$-amilase (Figura 8 ).

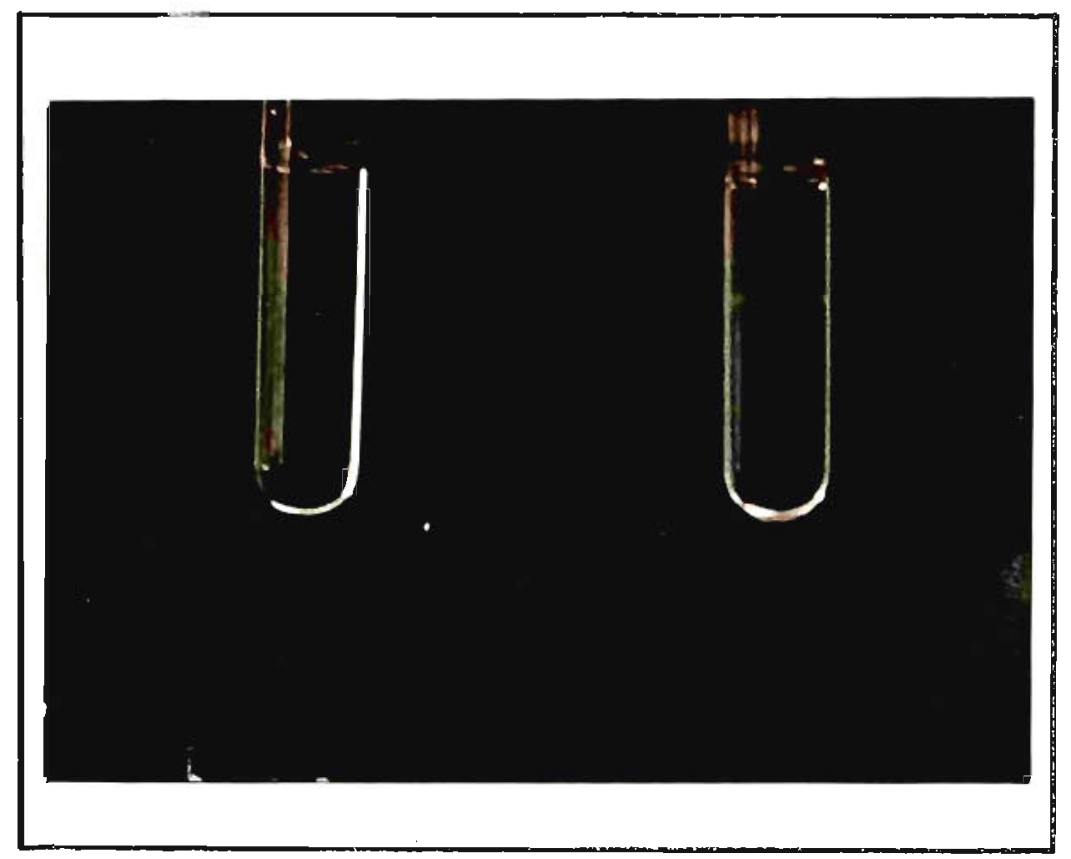

Figura 8 . Totografia de gradientes de DNA total de trofozoitos, centrifugados conforme descrito em Métodos. O tubo da direita contém nila não tratado com a-amilase a apresenta uma banda clana que desaparece após tratamento com a-amilase (tubo da esquerda). 
Portanto, o DNA total de trofozoitos apresenta um componente maior ( $84 \%$ do DNA celular total) e um componente menor (16\%), com densidades respectivamen te iguais a 1,717 e $1,692 \mathrm{~g} / \mathrm{cm}^{3}$. Os perfis do DNA total em gradiente preparativo e analítico de CsCl podem ser vistos nas figuras $9 b$ e 9B, respectivamente.

b) DNA nucleari de trofozoitos

O perfil do DNA nuclear, fragmentado até peso molecular igual a $6 \times 10^{5}$ daltons, tem uma distribui ção unimodal em gradientes de CsCl (Figura 9a), caracterizado por densidade igual a $1,717 \mathrm{~g} / \mathrm{cm}^{3}$ (Figura 9A). Esses resultados indicam claramente a origem nuclear do componente maior do DNA total (Figura 9B).
c) DNA mitocondrial de trofozoitos
O DNA de mitocôndrias isoladas conforme descrito em Métodos, foi purificado por fracionamento em gradientes de CsCl (Figura 10A). O perfil de sedimen tação obtido em gradientes analíticos (Figura 10B),mostra a existência de uma única banda, com densidade de flutuação igual a $1,692 \mathrm{~g} / \mathrm{cm}^{3}$.

d) DNA total de cistos

O perfil do DNA de cistos em gradientes de CsC1 (Figura 11A), mostra a presença de dois componentes com densidades idênticas a dos componentes do DNA total de trofozoitos: 1,717 e $1,692 \mathrm{~g} / \mathrm{cm}^{3}$ (Figura 11B). o componente maior representa aproximadamente $93 \%$ do DNA celular total e o componente menor $7 \%$. 

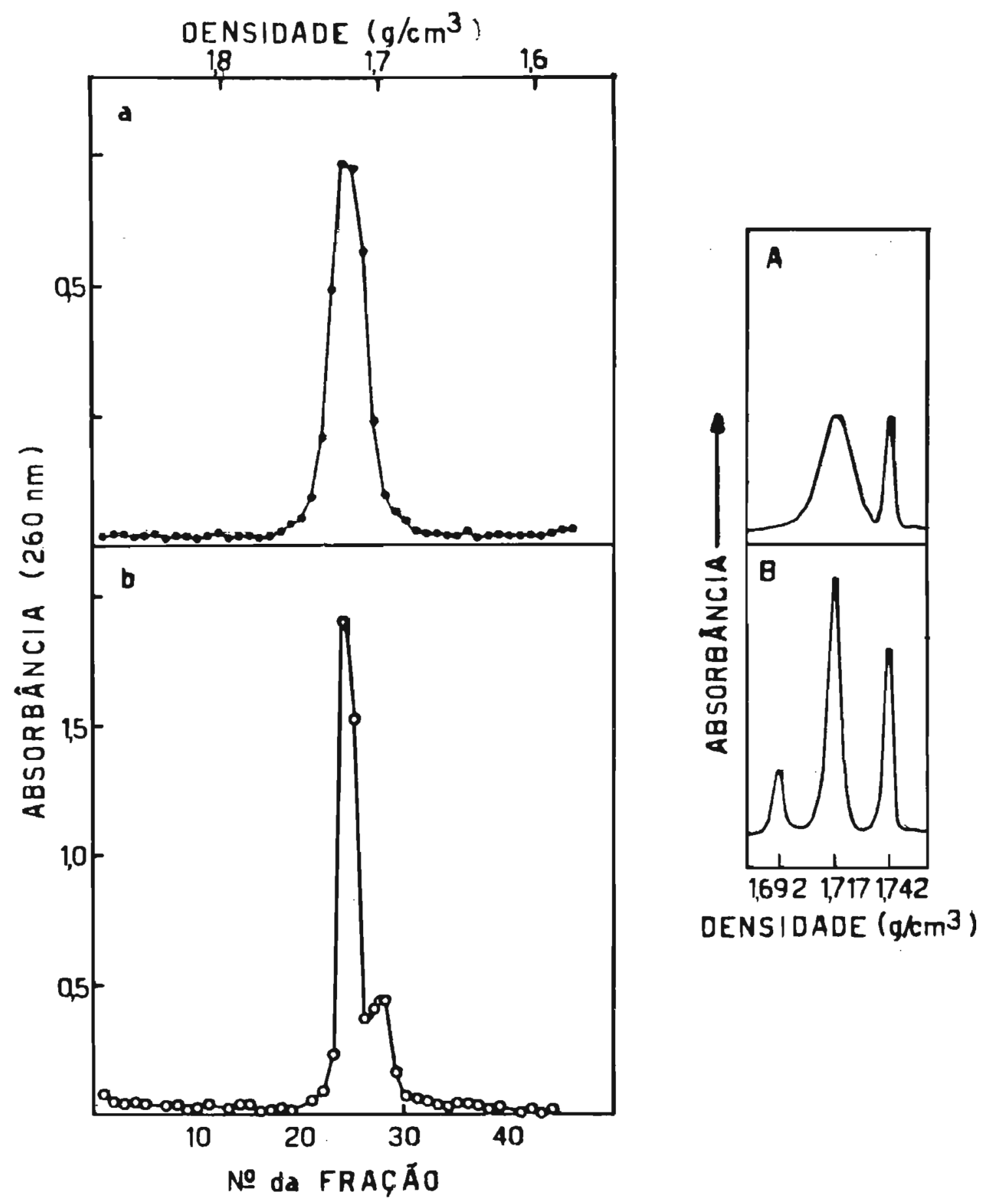

Figura 9 - Centrifugação em gradientes de CsCl de DNA total e nuclear de trofozoitos. As figuras a e b mostram os resultados de gradientes preparativos contendo, respectivamente, $157 \mu \mathrm{g}$ de DNA nuclear frag mentado $\left(P M=6 \times 10^{5}\right)$ e $109 \mu \mathrm{g}$ de DNA total nativo. 0 perfil de $A_{260}$ após centrifugação isopícnica e as densidades obtidas são apresentadas na figura A ( DNA nuclear) e figura B (DNA total). DNA marcador de fago 2c tem densidade igual a $1,74.2 \mathrm{~g} / \mathrm{cm}^{3}$. 

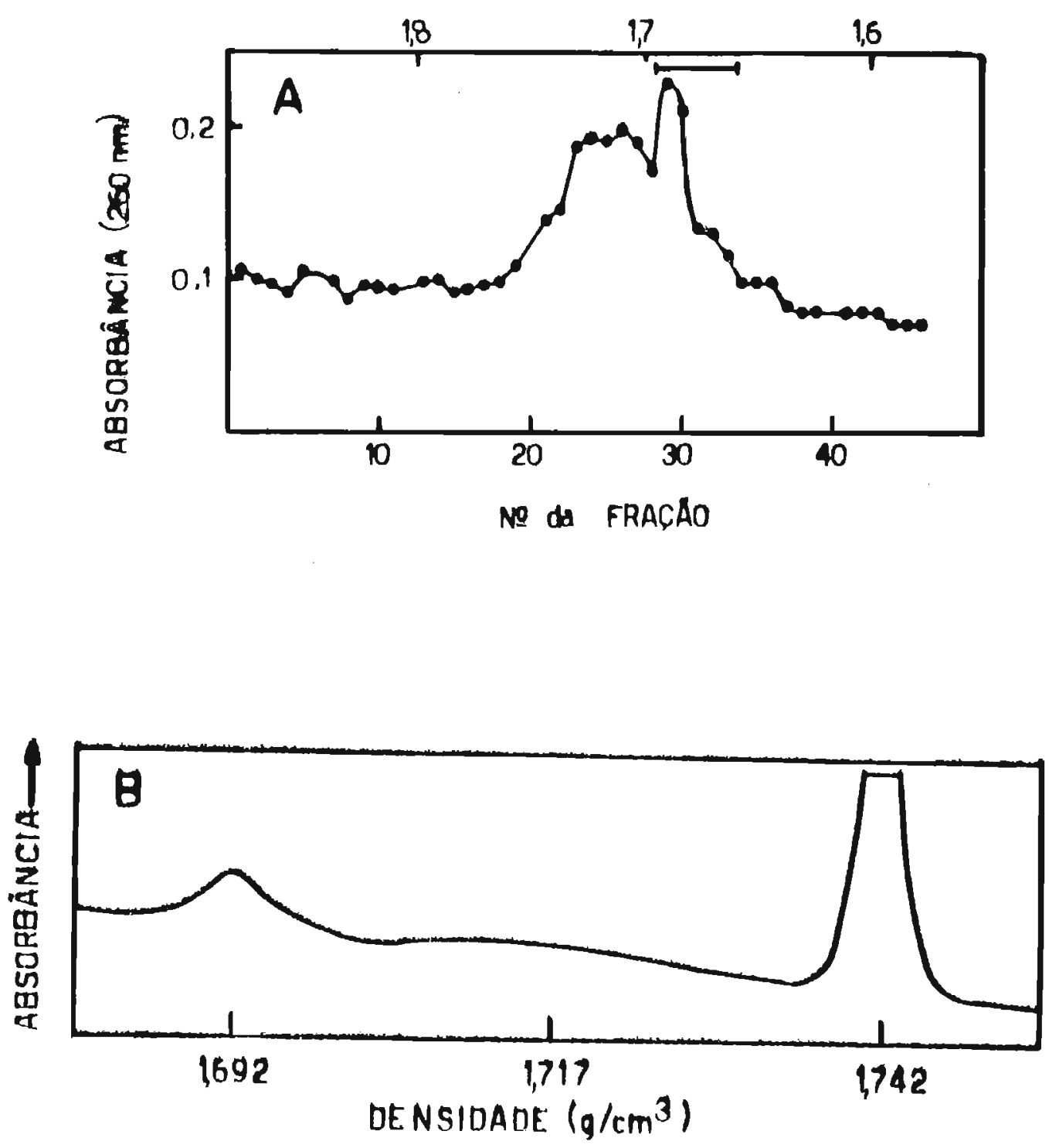

Figura 10 - Gentrifugação de DNA mitocondrial em gradientes de CsCl. A figura A mostra o perfil de absorbância de $60 \mu \mathrm{g}$ de DNA, fracionado por centrifugação em gradiente preparativo. A barra indica as frações que foram reunidas, dializadas contra NaCl 0,01 M e submetidas à centrifugação analítica, cujo traçado fotoelétrico pode ser visto na figura B. A contaminação por material com densidade igual a $1,717 \mathrm{~g} / \mathrm{cm}^{3}$ é muito baixa. O marcador de densidade é o DNA do fago $2 \mathrm{C}\left(\rho=1,742 \mathrm{~g} / \mathrm{cm}^{3}\right)$. Condições de centrifugação descritas em Métodos. 

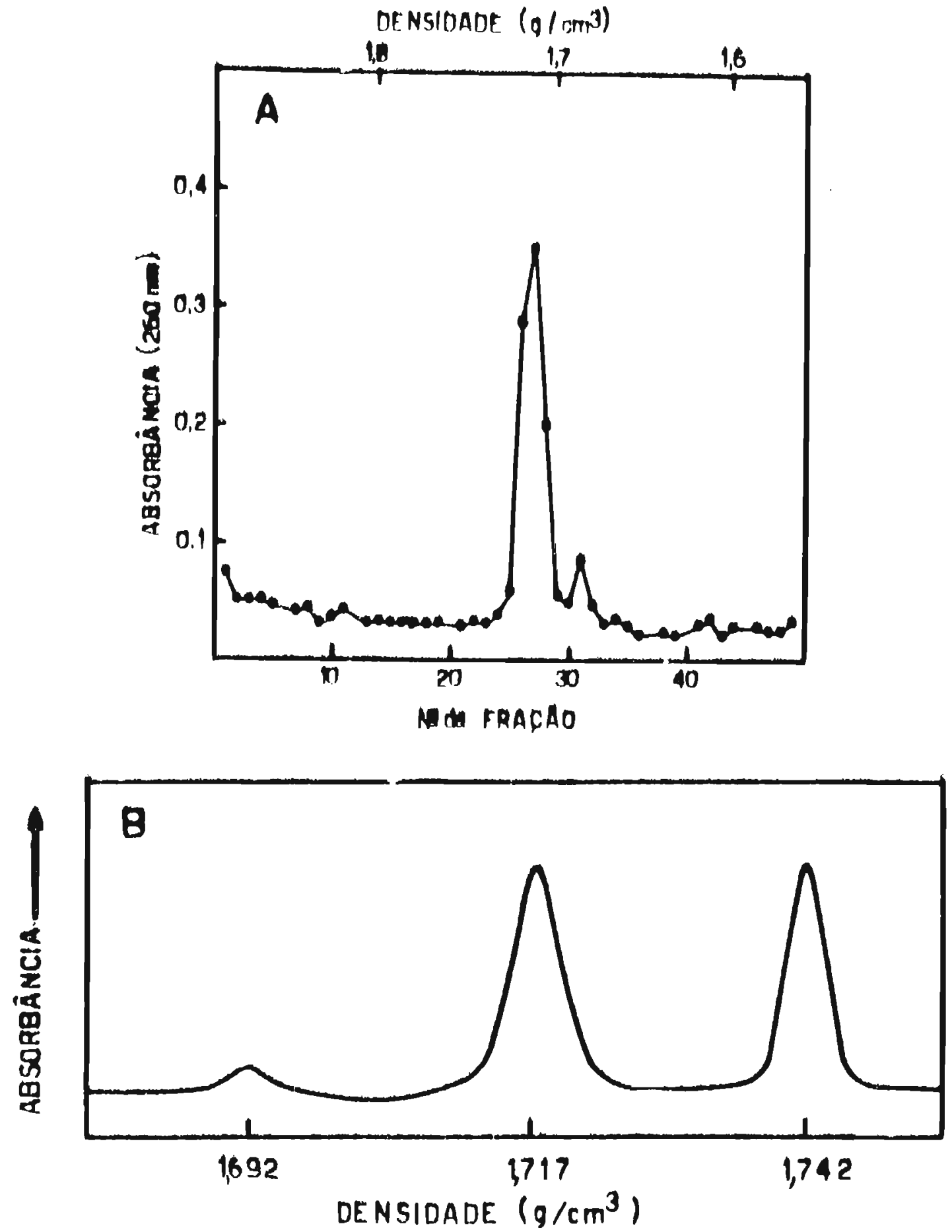

Figura ll - Centrifugação de DNA total de cistos de $\mathbf{A}$. castellanii em gradientes de CsCl.Os picos obtidos por centrifugação preparativa de $34 \mu \mathrm{g}$ de DNA (Figura A), são caracterizados pelos valores de densidade de flutuą̧ão mostrados no perfil fotoelétrico obtido na centrífuga analítica (Figura B). DNA de fago $2 \mathrm{C}\left(\rho=1,742 \mathrm{~g} / \mathrm{cm}^{3}\right)$ é o marcador utilizado. Maiores detalhes em Métodos. 
e) DNA total de trofozoitos em diferentes estágios de crescimento.

A figura 12 mostra o perfil, em gradientes de CsCl analíticos do DNA de células em fase logarítmica precoce (12A), mediana (12B) e tardia ( $12 \mathrm{C}$ ). Aparentemente, há uma variação da fração do DNA celular representada pelo componente menor. A tabela 4 resume as características de cada fase da cultura quan-. to à densidade de células, número de cistos e porcelıtagem do componente menor.

Tabela 4 - Variação da porcentagem do componente menor do DNA total de trofozoitos em diferentes fases de crescimento.

\begin{tabular}{lccc}
\hline $\begin{array}{l}\text { Etapas da } \\
\text { fase } \log \end{array}$ & $\begin{array}{c}\text { No de células } \\
\text { por ml }\end{array}$ & $\begin{array}{l}\% \text { de cis- } \\
\text { tos }\end{array}$ & $\begin{array}{l}\% \text { do compo- } \\
\text { nente menor }\end{array}$ \\
\hline Precoce & $4 \times 10^{4}$ & zero & 4 \\
Mediana & $5 \times 10^{5}$ & 1 & 16 \\
Tardia & $1 \times 10^{6}$ & 11 & 6 \\
\hline
\end{tabular}

o no de cél/ml e a \% de cistos foram determinados por contagem em câmara de Neubauer. As etapas da fase logaritmica foram delimitadas de acordo com as curvas de crescimento de culturas agitadas em erlenmeyers (Figura 1).As porcentagens do componente menor, em relação ao DNA total, foram obtidas a partir da área dos picos obtidos por centrifugação em CsCl ( Figura 12). Os resultados representam a média de dois experimentos isolados。 


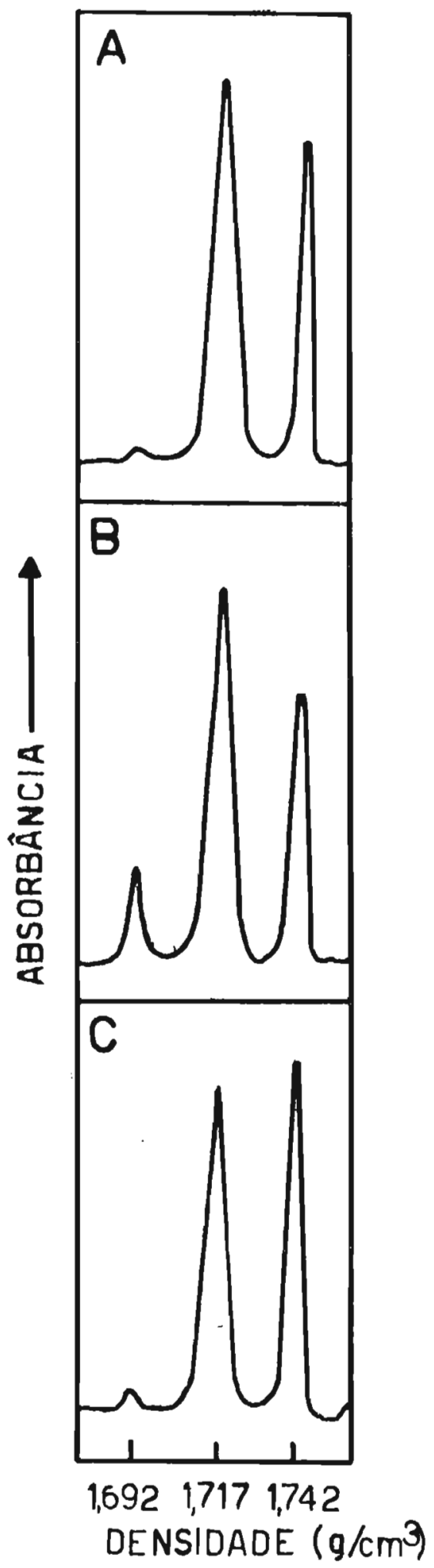

Figura 12 - Traçado do registro fotográfico obtido após centrifugação analítica em gradientes de CsCl de DNA total de trofozoitos em diferentes fases de crescimento. As figuras A, B e C, representam, respectivamente, os resultados obtidos com DNA de células em fase logaritmica precoce, mediana e tardia. DNA de fago $2 \mathrm{C}\left(\rho=1,742 \mathrm{~g} / \mathrm{cm}^{3}\right)$ é o marcador de densidade utilizado. Condições de centrifuga ção descritas em Métodos. 


\section{Perfil de fusão dos componentes do DNA} de trofozoito

a) DNA total

A figura 13 mostra a desnaturação do DNA total, onde a transição ocorre ao longo de um grande intervalo de temperaturas. A primeira derivada do perfil de fusão (Figura 13A), confirma a existência de dois componentes, caracterizados por valores de $\mathbb{T}_{\mathrm{m}}$ iguais a $75,5^{\circ} \mathrm{C}$ (componente maior) e $63^{\circ} \mathrm{C}$ (componente menor). A determinação do $\mathrm{T}_{\mathrm{m}}$ foi feita para os dois componentes, após fracionamento por centrifugação em gradientes de CsCl.

b) Componente maior do DNA total e DNA nuclear

A transição em torno do $T_{m}$ é abrupta (Figu ra 14a) e a curva derivada (Figura 14A) mostra um pico gaussiano. o valor médio de $\mathrm{T}_{\mathrm{m}}$ é igual a $75,5^{\circ} \mathrm{C}$. O DNA nuclear apresentia comportamento idêntico ao componente maior (ver figura 14).

c) Componente menor e DNA mitocondrial

O componente menor (Figura $15 \mathrm{~A}$ e B), não apresenta uma curva derivada simétrica, distinguindo-se três componentes com $\mathrm{T}_{\mathrm{m}}$ em torno de $62 ; 65$ e $75^{\circ} \mathrm{C}$. A figura 15 A mostra, ainda, a curva derivada do perfil de fusão do DNA mitocondrial, também plurimodal, mas que não se sixperpõe à curva derivada do componente menor. 

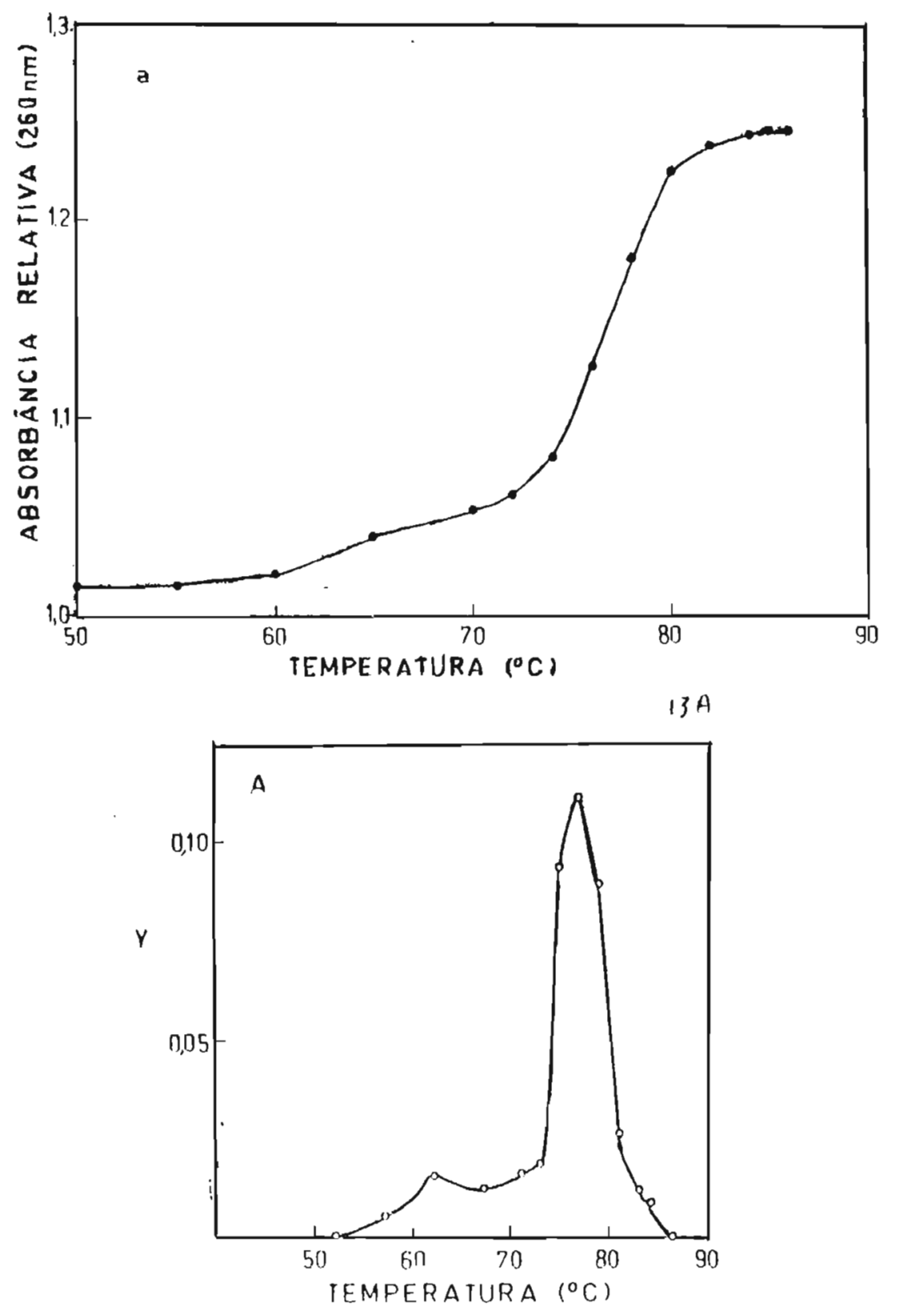

Figura 13 - Curvas de desnaturação tèrmìa do DNA total de trofozoitos, em 0,15SC (24 $\mu \mathrm{g} / \mathrm{ml})$. A figura a mostra a variação de absorbância relativa (corrigida para expansão térmica), em função da temperatura da solução. A f'igura $\underline{A}$ mostra a curva diferen cial de fusão, onde a ordenada ( $Y$ ) indica a variação da $\%$ de hipercromicidade por grau:

$$
Y=\frac{\left(A t_{1}-A t_{2}\right) /\left(A_{100}-A_{25}\right)}{\left(t_{1}-t_{2}\right)}
$$

onde $A t_{1}, A t_{2}, A_{100} \in A_{25}$ são as absorbâncias medidas nas temperaturas $t_{1}, t_{2}, 100$ e $25^{\circ} \mathrm{C}$, respectivamente. Os valores na abcissa são iguais a $t_{-}+t_{2} / 2$. As absorbâncias foram determinadas em um espectrofotômetro Zeiss PMQII, colforme descritu em Métodos. 

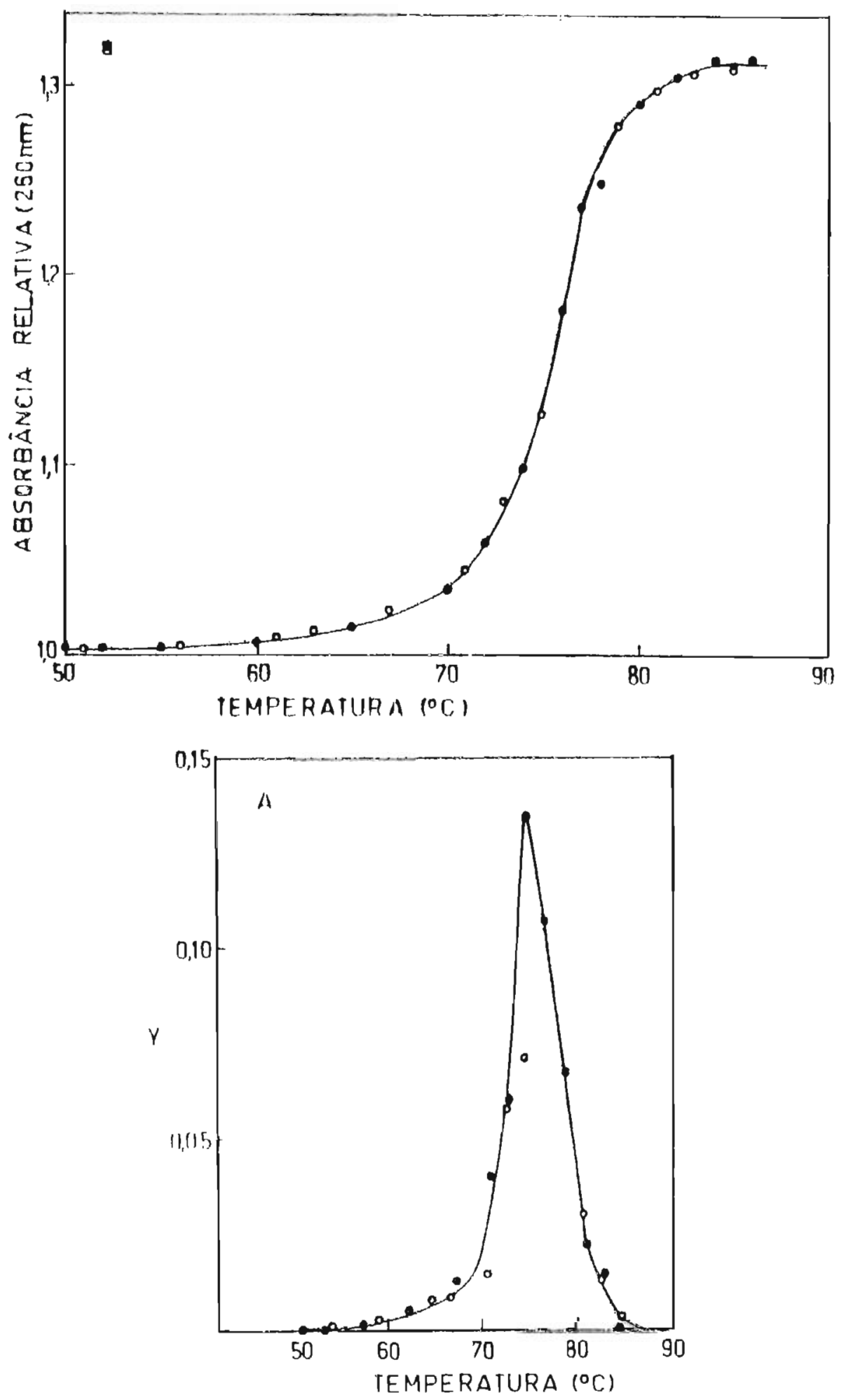

Figura 14 - Perfil de fusão do DNA nuclear e componente maior do DNA total de trofozoitos, em. $\mathrm{O}_{2} 1$ SSC. Os valores de absorbância relativa das soluçoes de DNA nuclear ( $18 \mu \mathrm{g} / \mathrm{ml}$, círculos cheios) e componente maior (20 $\mu \mathrm{g} / \mathrm{ml}$, círculos vazios), corrigidos para expansão térmicã, são registrados em função da temperatura da solução (Figura a). A figura A mostra a curva derivada da desnaturaçäo, onde a ordenada (Y) representa o incremento em absorbância relativa por grau. No eixo das abcissas estão indicadas as temperaturas médias dos intervalos. Para maiores detallies, ver legenda da figur:a 7.3 . 

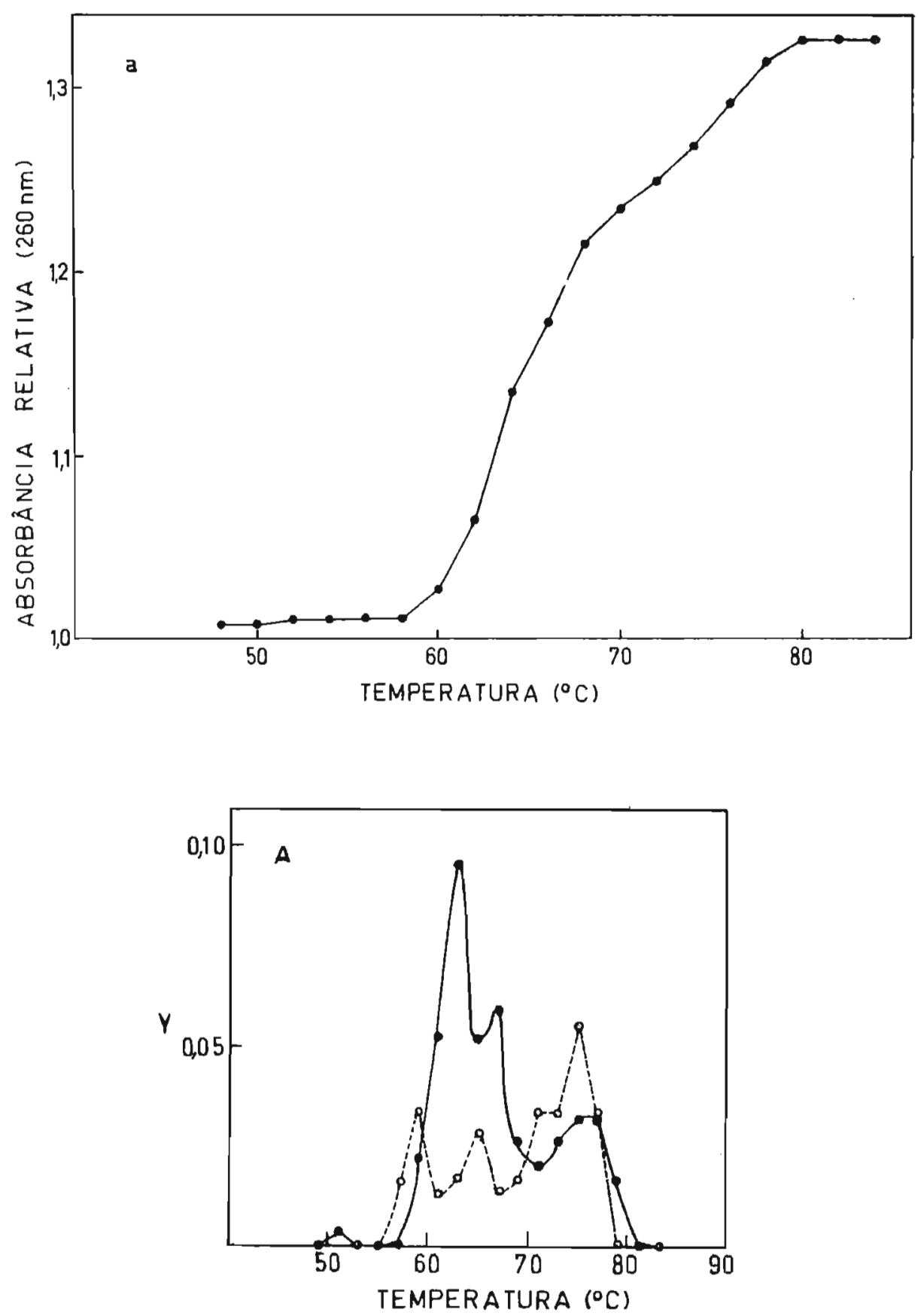

Figura 15 - Perfil de desnaturação térmica do componente menor do DNA total de trofozoitos $(14 \mu \mathrm{g} / \mathrm{ml})$, em 0,1 SSC. A figura a representa a variação de absorbância relativa, corrīgida para expansão de volume, em. função da temperatura. Na curva diferencial de fusão (Figura A), as ordenadas indicam a variação da \% de hipercromicidade por grau. Os valores em abcissas referem-se à temperatura média dos inter valos considerados. A figura A mostra, ainda, os resultados obtidos com uma preparação de DNA mitocondrial ( $13 \mu \mathrm{g} / \mathrm{ml}$, círculos vazios), que exibe comportamento heterogêneo, corno o componente menor (clrculos cheios). Maiores detalhes na legenda da Figura 13. 
A tabela 5 resume algumas característi cas do DNA de trofozoitos.

Tabela 5 - Propriedades físicas dos componentes do DNA de trofozoitos de A. castellanii.

\begin{tabular}{|c|c|c|c|c|}
\hline \multirow[t]{2}{*}{ DNA } & \multirow{2}{*}{$\begin{array}{l}\text { Densidade } \\
\left(\mathrm{g} / \mathrm{cm}^{3}\right)\end{array}$} & \multirow{2}{*}{$\begin{array}{c}\mathrm{T}_{\mathrm{m}} \\
\left({ }^{\mathrm{O}} \mathrm{C}\right)\end{array}$} & \multicolumn{2}{|l|}{$\% \mathrm{GC}$} \\
\hline & & & (densidade) & $\left(T_{m}\right)$ \\
\hline \multicolumn{5}{|l|}{ Total } \\
\hline componente maior & 1,717 & 75,5 & $58, \mathfrak{c}$ & 52,7 \\
\hline componente menor & 1,692 & 63,0 & 32,7 & 22,2 \\
\hline Nuclear & 1,717 & 75,5 & 58,2 & 52,7 \\
\hline
\end{tabular}

A determinação de densidade e $T_{m}$ está descrita em Métodos. A \% de GC (fraçăo molar) foi calculada a partir da densidade ou $\mathrm{T}_{\mathrm{m}}(\mathrm{em} 0,1 \mathrm{SSC}$ ) de cada DNA, segundo as equações empíricicas de Mandel et al. (1968) e Mandel e Marmur (1968).

\section{Renaturação de DNA}

Os resultados obtidos através da análise espectrofotométrica da cinética de renaturação, podem ser analisados segundo a equação proposta por Wetmur e Davidson (1968):

$$
\frac{1}{A-A_{\infty}}=2,04 \times 10^{-4} k_{2} t+\frac{1}{0,36 A_{\infty}}
$$

$A_{c o}=$ absorbância do DNA nativo (260nm)

$A=$ absorbância em tempo $t$ (segundos)

$k_{2}=$ constante de segunda ordem

Nessa equação, o fator de hipercromicidade (aumento de absorbância devido à desnaturạção), conside- 
rando-se um erro experimental de 5\%, é dado por:

$$
A_{0}-A_{\infty}=0,36 A_{\infty}
$$

$A_{O}=$ absorbância do DNA desnaturado

Portanto, colocando-se em um gráfico, os valores dos inversos da hipercromicidade residual $\left(1 / A-A_{\infty}\right)$, em função do tempo de reação, obtem-se uma linła reta. O coeficiente angular da reta, dividido por $\left(2,04 \times 10^{-4}\right)$, fornece o valur da constante de segunda ordem $\left(k_{2}\right)$.

A razão entre as velocidades de renaturação de dois DNAs com o mesmo peso molecular, obtido por métodos de trragmentação semeIhantes, é inversamente proporcional à razão entre o peso molecular das moléculaś de DNA não fragmentado (complexidade). Assim, a complexidade de um DNA pode ser obtida a partir da determinação experimential da constante de velocidade de renaturação desse DNA e de outro DNA corn complexidade conhecida, nas mesmas condições de incubação (Britten e Kohne, 1967; Wetmur e Davidson, 1968). DNAs de bactérias ou vírus são cinèticamente homogêneos, ou seja, sua renaturaçãc é represent renaturação de DNAs heterogeneos, como ocorre nos organismos superiores, forrece uma curva de renaturação complexa que pode ser subdividida em retas que represen tam a renaturaçõo de diferentes famílias de DNA.

Neste trabalho, a reação de renaturação foi acompanhada pela queda da absorbância a 260nm. As constantes de velocidade de renaturação dos diferentes componentes do DNA da ameba, foram calculadas a partir do coeficiente angular das retas obtidas em gráficos do tipo sugerido por Wetmur e Davidson (1968), mostrados nas figuras 16-19. As retias apresentadas representam as retas médias obtidas por um conjunto de pontos experimentais submetidos à análise de regressão 1inear, em um calculador Hewlett-Packard, modelo 9820A. o programa de regressão linear foi gentilmente cedido pela Dra. Helena Li Chum. O coeficiente de variância do desvio padrão da inclinação e do intercepto das re- 
tas era, em média, $5 \%$ e 0,4\%, respectivamente. 0 coeficiente de correlação médio era igual a 0,98 . Os valores de coeficiente angular e linear das retas médias foram submetidos ao teste $t$ de student, monocaudal, e foram considerados significativos nas 23 experiências de renaturação consideradas.

o padrão utilizado nas medidas de renaturação foi o DNA de E. colí, que é um DNA homogêneo , constituido predominantemente por sequências únicas e com complexidade bem estabelecida (Cairns, 1963). A figura 16 mostra a renaturição do DNA de E. coli, representada, conforme esperado, por uma única reta. A mesma figura mostra a renaturação do DNA celular total de trofozoitos de A. castellanii, que exibe comportamento heterogêneo. A curva de renaturação desse DNA pode ser dividida em 4 secções, indicando a presença de 4 familias de DNA com diferentes velocidades de renaturação. A contribuição de cada fração pode ser calculada por extrapolação da reta que representa a fração de renaturação mais lenta, ao valor de $1 / A-A_{\infty}$ em tempo zero de reação (Wells e Birnstiel, 1969). O inverso desse valor fornece a hipercromicidade devida à fração lenta. O mesmo procedimento é adotado para as outras frações. Comparando-se o valor obtido para cada frał̧ão com o valor de hipercromicidade total $\left(A_{0}-A_{\infty}=100 \%\right)$, é possível calcular a porcentagem do genoma correspon dente a cada família de DNA. Por analogia com as fami lias do DNA de outros organismos superiores (Britten et al., 1972), as familias de DNA da ameba foram denominadas de "rápida", "intermediária", "lenta" e "única",admitindo-se que a fração que renatura mais lentamente seja constituída por DNA "único". Os valores médios de porcentagem obtidos para as familias do DNA total foram respectivamente de: $86 ; 7,5 ; 4$ e 2,5\%。

Após longos períodos de incubação, quando a maior parte das sequêricias com renaturação rápida já reagiu, a inclinação da curva de renaturação representi, efetivamente, a fração de DNA com renaturação mais lenta (DNA "único")。 Como essa fração representa a 

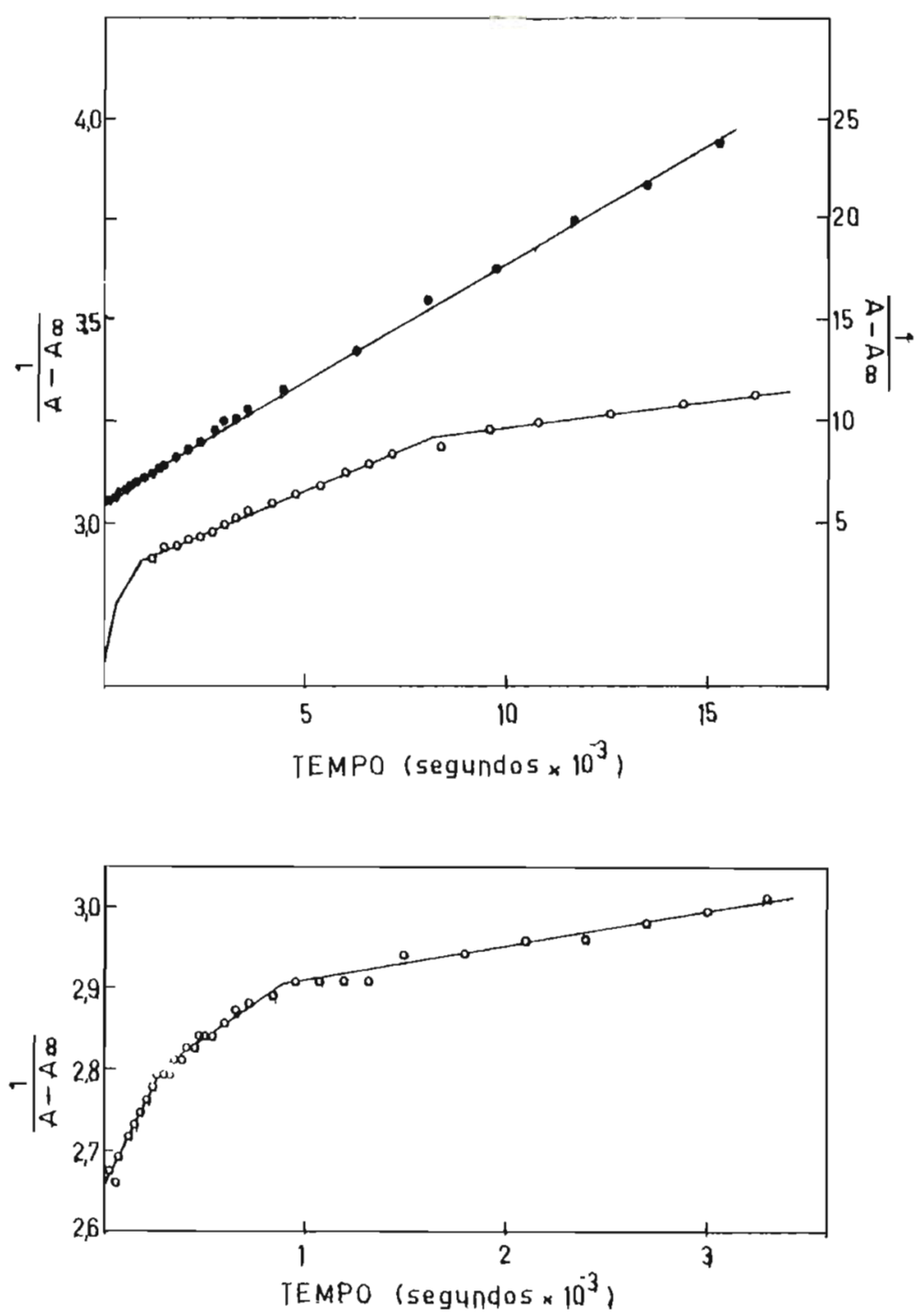

Figura 16 - Renaturação do DNA total de trofozoitos de A. castellanii $(49 \mu \mathrm{g} / \mathrm{ml})$ e DNA de E. coli $(32 \mu \mathrm{g} / \mathrm{ml})$, em $\mathrm{NaCl} I \mathrm{M} \mathrm{a} 60^{\circ} \mathrm{C}$. Os valores do inverso da hipercromicidade residual são medidos em função do tempo de reação. $\mathbf{A}_{\infty}$ e $\mathbf{A}$ representam, respectivamente, a absorbância a 260nm, das soluções de DNA nativo e DNA parcialmente renaturado em diferentes tempos de reação. DNA de E. coli (círculos cheios, ordenada do lado direito), mostra a relação linear esperada e DNA total da ameba (círculos vazios, ordenada do lado ésquerdo) comporta-se heterogêneamente. Porcentagens do genoma da ameba são obtidas a partir dos interceptos das diferentes seç̧ões da curva de reassociação,obtidos por regressão linear. A metade inferior da figuru representa, em escala aumentada, os dados relativos à parte inicial (tempo de incubação de zero a $3 \times 10^{-3}$ seg.) da rea ção de renaturação do Dria total da ameba. 
maior parte do genoma $(86 \%)$, pode-se assumir que o $k_{2}$ aparente, calculado a partir da inclinação final da curva de renaturação (Figura 16, 4 reta do DNA total; Tabela 6), aproxima-se muito da constante verdadeira de segunda ordem para o DNA de renaturação mais lenta (DNA "único").

Tabela 6 - Cinética de renaturação de diferentes frações do DNA total de trofozoitos de A. castellanii.

\begin{tabular}{lcc}
\hline DNA & $\begin{array}{c}\text { Peso Molecular } \times 10^{5} \\
\text { (daltons) }\end{array}$ & $\mathrm{k}_{2}$ \\
\hline componente menor & 5,4 & $\begin{array}{c}23,5 \\
6,7\end{array}$ \\
& 4,9 & 0,68 \\
\hline mitocondrial & 15,4 & 5,2 \\
\hline componente maior & 6,2 & 0,69 \\
\hline nuclear & 10,7 & 0,109 \\
\hline total (4a reta) & 9,5 & 0,118 \\
\hline E. coli & 4,09 \\
\hline
\end{tabular}

Os DNAs foram dissolvidos em $\mathrm{NaCl}$ I M e incubados a $60^{\circ} \mathrm{C}$. A cinética de renaturação foi analisada pelo método óptico e as constantes aparentes de velocidade calculadas segundo Wetmur e Davidson (1968). Os valores de $k_{2}$ (média de 3 determinações), foram normalizados para $P M=9,5 \times 10^{5}$ daltons (Wetmur e Davidson, 1968). O peso molecular foi determinado conforme descrito em Métodos. Unidades de $k_{2}=\operatorname{mol} \cdot \mathrm{seg} \cdot 1^{-1}$ ). 
o cálculo das constantes de velocidade das familia, de renaturação mais rápida, é prejudicado pelo número relativamente grande de componentes, de modo que a renatur.ção de cada família é afetada pela renaturação da outra. Além disso, quando se analisa a renaturação das famílias que reagem inicialmen te, a contribuição de hipercromicidade de cada fração está sendo constantemente alteradá pela fração lenta, presente em todas as. fases da renaturação Quan do apenas dois componentes estão presentes, pode-se conseguir uma aproximação do valor de $k_{2}$ verdadeiro para a fração "rápida", através do método de correção sugerico por Wetmur (1967) e Wells e Birnstiel (1969)。Balsamo (1972) sugeriu um método de correção adequado para a determinação do $k_{2}$ verdadeiro quan do existem tres familias com velocidades de renaturação diferentes. A superposição das retas na renaturação do DNA total da ameba dificulta o cálculo das constantes aparentes e o número de componentes observa do impede a aplicação dos métodos de correção citados.

Uma melhor resolução entre as retas pode ser obtida através da renaturação dos dois compo nentes do DNA total da ameba, isolados em gradientes de $\mathrm{CsCl}$.

A figura 17 mostra o perfil de renatura ção do componente menor do DNA total de trofozoitos que apresenta um comportamento cinético heterogêneo, com tres velocidades de renaturação diferentes, caracterizadas pelos valores de $\mathrm{k}_{2}$ aparentes citados na tabela 6. O componente maior (Figura 18)comporta-se como um DNA muito homogêneo, não apresentando sequências com renaturação rápida. O valor médio da constante de segunda ordem para a reação observada, encontra-se na tabela 6 .

DNA de núcleos isolados apresenta características de renaturação pràticamente iguais âs do componente maior (Figura 18 e Tabela 6). A comparação entre a porcentagem do genoma, perfil de renaturação e valores de $k_{2}$ do componente maior, DNA nuclear e 

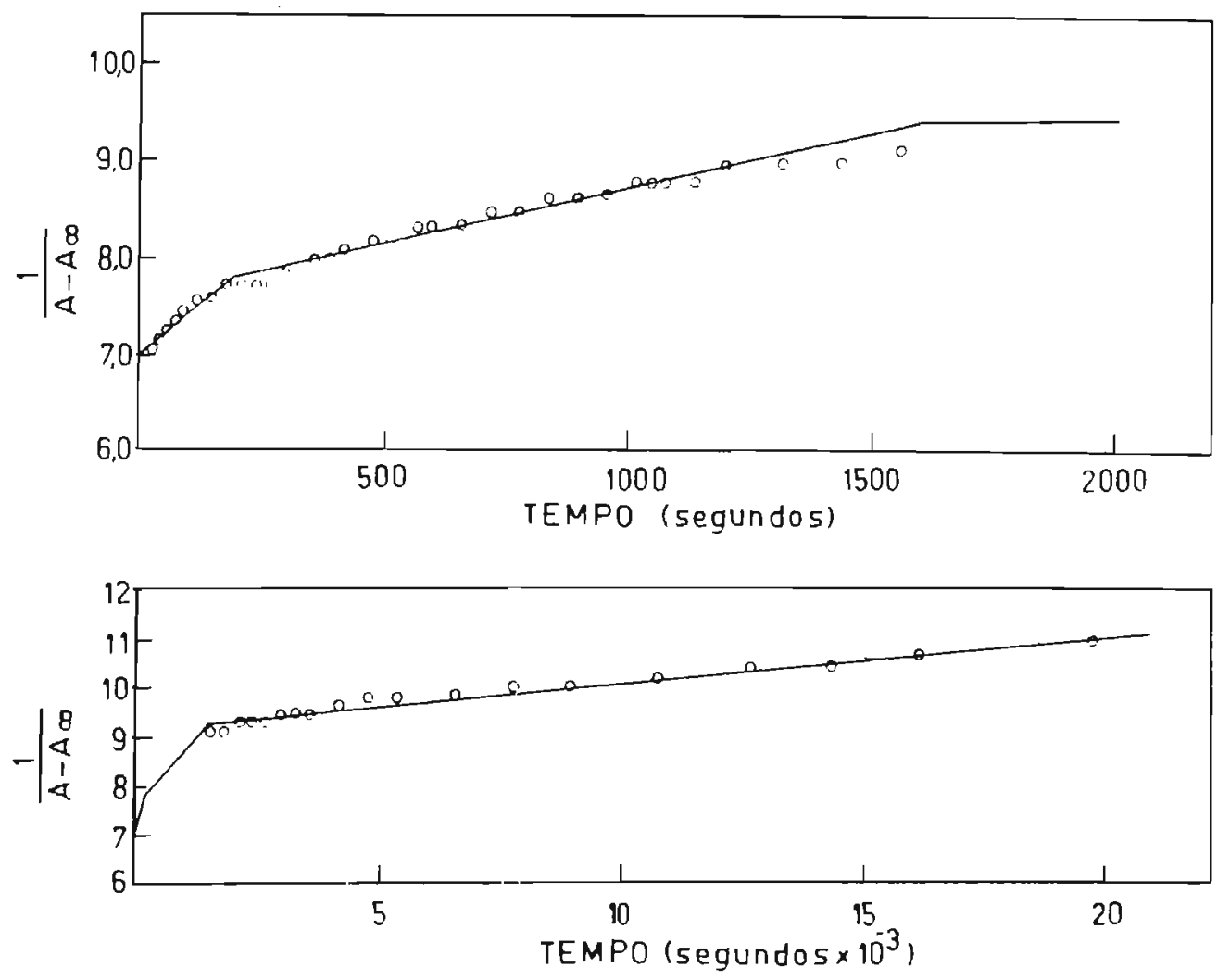

H'igura 17 - Renaturação do componente menor do DNA total de trofozoitos de $\underline{A}$. castellanii. o componente menor foi isolado por centrifugą̧ão em gradientes de CsCl, dissolvido em $\mathrm{NaCl} l \mathrm{M}$ e incubado a $60^{\circ} \mathrm{C}$. A metade inferior da figura representa a reação em tempos maiores de incubação, mostrando apenas as retas da figura superior que mostra, em escala aumentada, os dados para os primeiros $2000 \mathrm{seg}$. de renaturacão. As constantes aparentes $\left(k_{2}\right)$ são calculadas a partir do coeficiente angular das tres retas obtidas por regressão linear - As abrevinãos empregadas são as mesmas da Figura 16. 


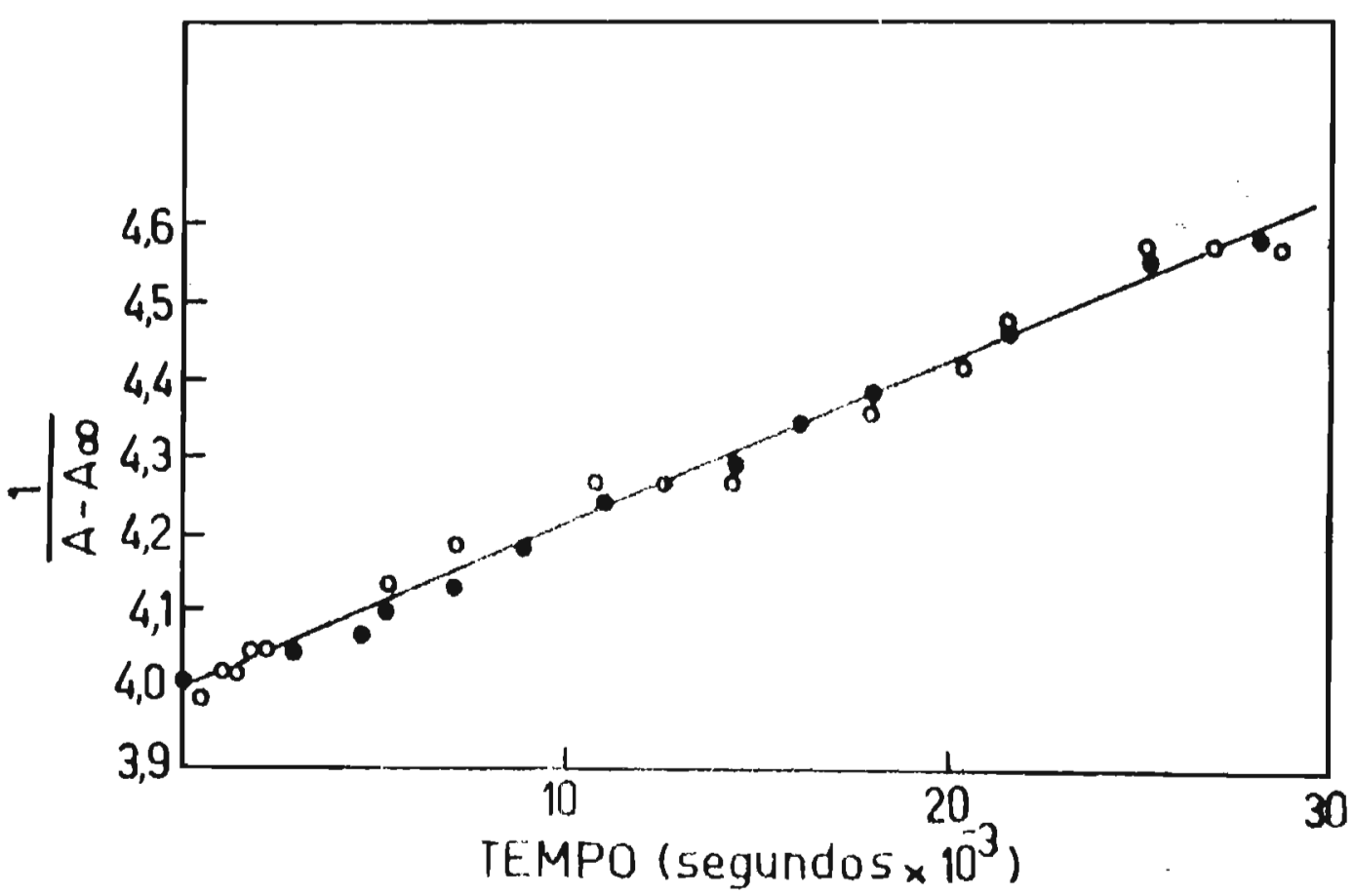

Figura 18 - Renaturação do DNA "único" de trofozoitos de $A$. castellanii. O componente maior (54 $\mu \mathrm{g} / \mathrm{ml}$ ), purificado em gradientes de CsCl e o DNA nuclear $(53 \mu \mathrm{g} / \mathrm{ml}$ ) foram dissolvidos em NaCl I M e incubados a $60^{\circ} \mathrm{C}$. Os círculos vazios e cheios representam a renaturação do conponente maior e DNA nuclear respectivamente. A constante de segunda ordem $\left(k_{2}\right)$ foi calculada segundo Wetmur e Davidson (1968), a partir da inclinação da reta média obtida por regressão linear. Para maiores detalhes, ver legenda da Figura 16. 
4a reta do DNA total, indica que esses componentes se referem à fração do DNA da ameba que apresenta renatura ção majis lenta (fração "única"). A partir do valor da constante de renaturação do DNA de E. coli, renaturado nas mesmas condições, é possível estimar a complexida-de do DNA ruclear (fração "ún.i.a"), por comparação com o genoma de E. coli, igual a $2,7 \times 10^{9}$ daltons (Cairns, 1963). Para isso, os valores de $k_{2}$ observados foram normalizados para o mesmo peso molecular, através da equação proposta por Wetmur e Davidson (1968), que demonstra a proporção existente entre a raiz quadrada do peso molecular e a constante de segunda ordem. A partir do valor médio de $k_{2}$ determinado para a fração "única" $(0,106)$, a complexidade do DNA nuclear de $\underline{A}$. castellanii pode ser estimada em $1,46 \times 10^{11}$ daltons.

A renaturação do DNA de mitocôndrias também é heterogênea, mostrando a existência de duas frações (Figura 19), com velocidades de renaturação definidas por constantes aparentes, cujos valores estão na Tabela 6. Esses resultados indicam que o componente menor do DNA total não é exatamente idêntico ao DNA de mitocôndria que não contém as sequências de renaturação "rápida", mas contém as sequências de renaturação "intermediária" e "lenta".

As constantes verdadeiras para as diferentes familias presentes no DNA mitocondrial e componente menor poderiam ser obtidas através da aplicação dos métodos de correção mencionados anteriormente (Wetmur, 1967; Wells e Birnstiel, 1969; Balsamo, 1972), desde que a fração "lenta" apresentasse características cinéticas de DNA "único". Entretanto, os resultados obtidos (localização mitocondrial, valor de $k_{2}$ aparente e porcentagem do genoma), podem ser interpretados supondo-se que essa fração do DNA fôsse constituida por sequências com baixa trequência de repetição. Esse resultado torna muito difícil o cálculo do $k_{2}$ verdadeiro e, consequentemente, da complexidade cinética das famílias do componente menor e DNA mitocondrial, a partir de gráficos do tipo sugerido por Wetmur e Davidson (1968). 


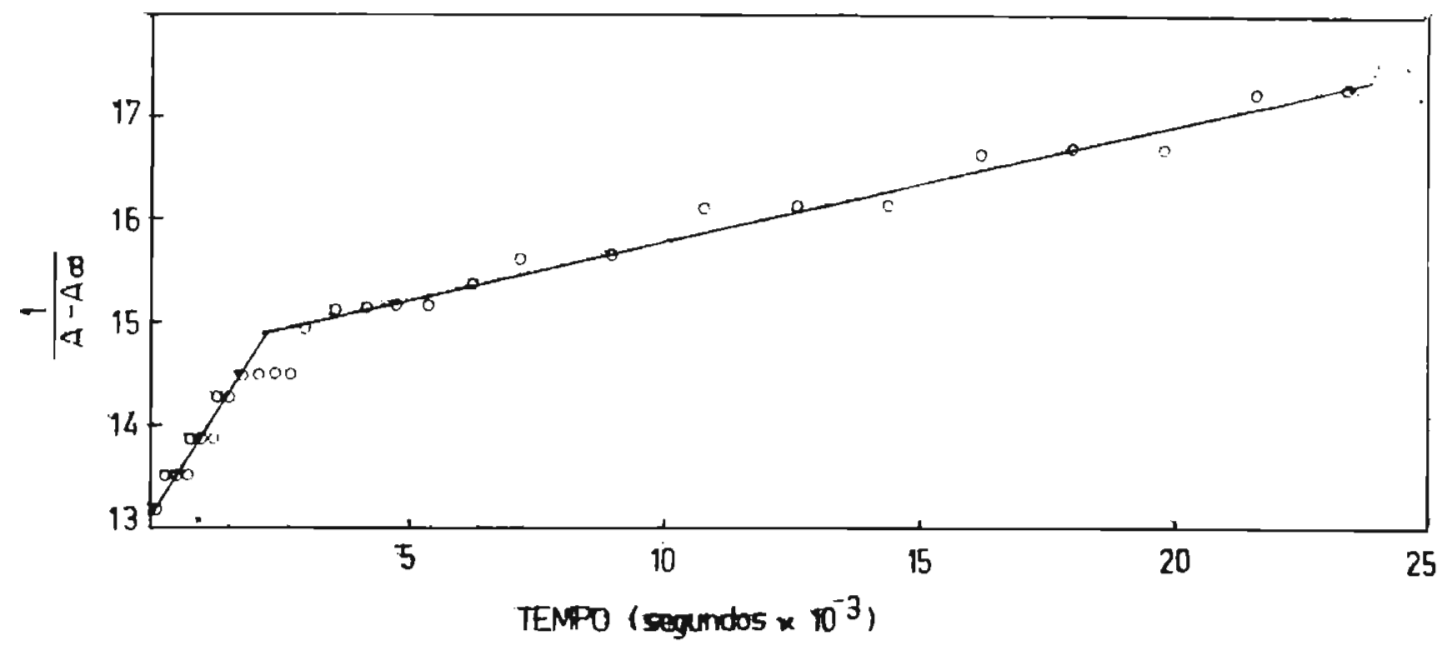

Figura 19 - Renaturaçf́o do DNA mitocondrial de trofozoitos de $\mathbf{A}$. castellanii. DNA de mitucôndrias isoladas conforme descrito em Métodos, foi dissolvido em $\mathrm{NaCl} I \mathbb{M}(18 \mu \mathrm{g} / \mathrm{ml})$ e reassociado a $60^{\circ} \mathrm{C} .0 \mathrm{k}_{2}$ aparente das duas retas componentes foi de terminado a partir do coeficiente angular obtido por regressão linear. As abreviações empregadas são as mesmas da Figura 16. 
Todavia, os resultados de cinética de renaturação rodem ser apresentados de maneira mais conveniente, cunforme sugerido por Britten e Kohne (1967), o que constitui um método alternativo para a determi nação da complexidade cinética e tem a vantagem de permitir a comparação entre reaç̋̃es com concentrações diferentes de DNA, além de mostrar claramente se o DNA em estudo é homogêneo ou não. Neste tipo de gráfico (Figuras 20 e 21), a fração de DNA reassociado $\left(A_{0}-A_{1} A_{0}-A_{\infty}\right)$ é colocada em função do logarítmo do produto da concentração inicial de DNA pelo tempo de reação (log Cot). Os valores de "Cot" são expressos em moles de nucleotídios por litro por segundos (mol.seg. $1^{-1}$ ). Cot igual a I resulta da incubação por 1 hora de DNA em uma concentração de $100 \mu \mathrm{g} / \mathrm{ml}$. Nesse tipo de gráfico, uma reação ideal de segunda ordem fornece uma curva simétrica, cuja parte central se ajusta a uma re ta. A inclinação dessa reta é estimada pela razão entre os valores de cot que a linha intercepta no início e fim da reação e serve como diagnóstico na determinação do grau de homogeneidade do DNA. Para uma reação ideal, a razão é próxima de 100 ( 2 unidades de $\log$ de Cot); se a razão for maior do que 100, a reação é heterogênea, isto é, espécies com velocidades de renaturação diferentes estão presentes.

Britten e Kohne (1967) desenvolveram equações que permitem analisar a cinética de renatura çăo, considerando cot como o parâmetro que controla a velocidade da reação. No caso de DNA único, o cot necessário para $50 \%$ de reassociação $\left(\operatorname{Cot}_{1 / 2}\right)$, é proporcional ao tamanho do genoma $(G)$ :

$$
\operatorname{Cot}_{1 / 2}=\frac{G}{K}
$$

A constante de proporcionalidade (K) avaliada pela medidiz, em condições idênticas, da velocidade de reassociação do DNA de um organismo com genoma conhecido, sem repetição significativa.

Quando uma família de DNA formada por uma sequência de nucleotidios repetida $x_{i}$ vezes esti- 


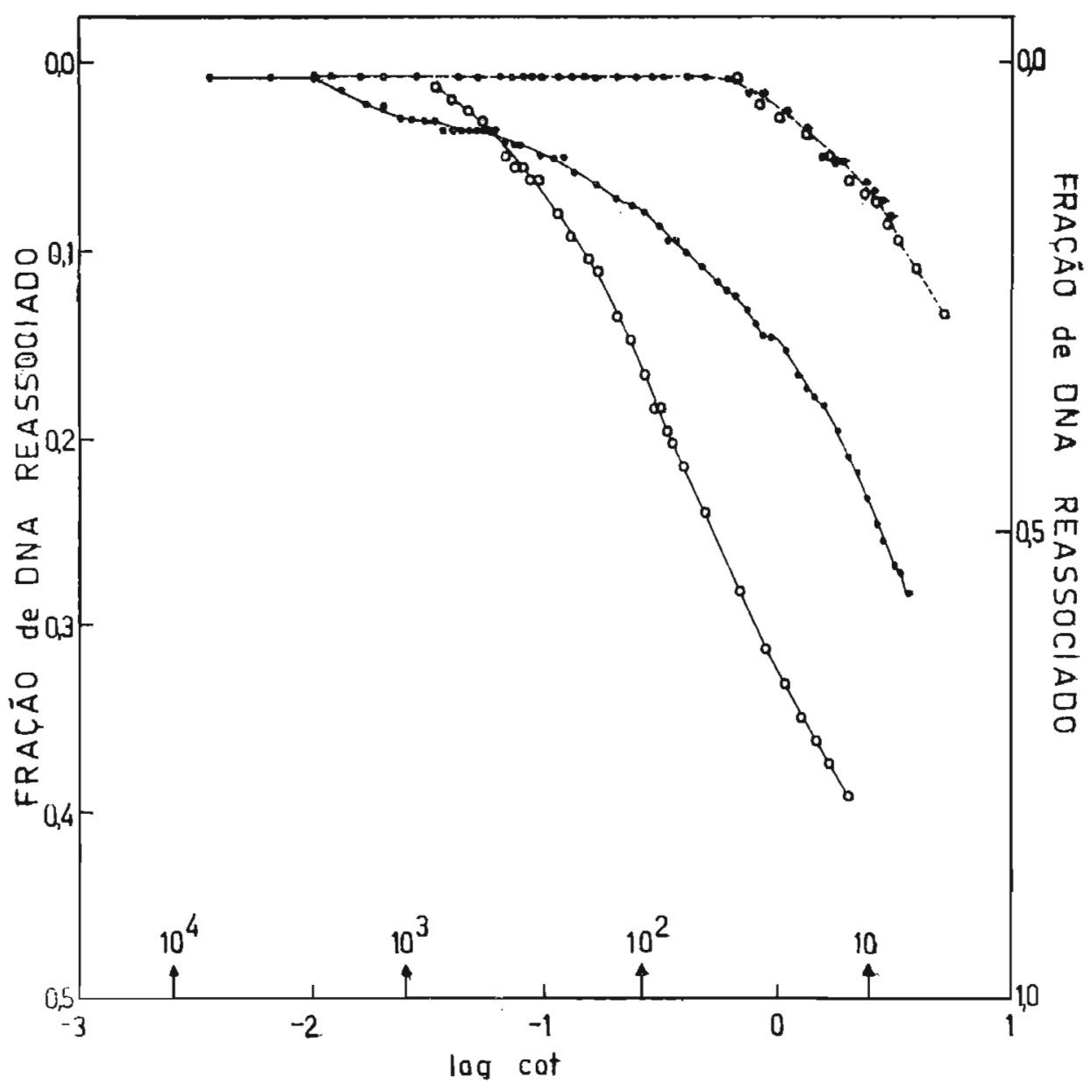

Figura 20 - Renaturação de diferentes preparações de DNA. A reassociação (NaCl I M; 60o0), foi medida espectrofotomètricamente, pela hipocromicidade de senvolvida a 260nm. A fração de DNA reassociado (Ao-A/Ao-A ) é colocada em função do logaritmo do produto da concentração de DNA (Co) expressa em "molea de nucleotídios/l, pelo tempo de incubação (segundos) (Britten e Kohne, 1968). A ordenada no lado direito do gráfico, refere-se a renaturação do DNA de E. coli (linha cheia, círculos vazios) e a da esquerdà à renaturaçẫo do DNA total (linha cheia, circulos cheios) e nuclear (linha pontilhada, círculos cheios e vazios) de trofozoitos de A. castellanii. A curva de reassociação do DNA nuclear (iinha pontilhada), ilustra o efeito da concentração de DNA na velocidade da reação: círculos vazios, $53 \mu \mathrm{g} / \mathrm{ml}$ e círculos cheios, $39 \mu \mathrm{g} / \mathrm{mi}$. As setas no eixo das abcissas indicam os valores de Cot onde metade do DNA deveria reassociar de acordo com vários graus de repetição. Concentração de DNA de E. coli $\theta$ DINA total $=33 \mathrm{\mu g} / \mathrm{ml}$. 


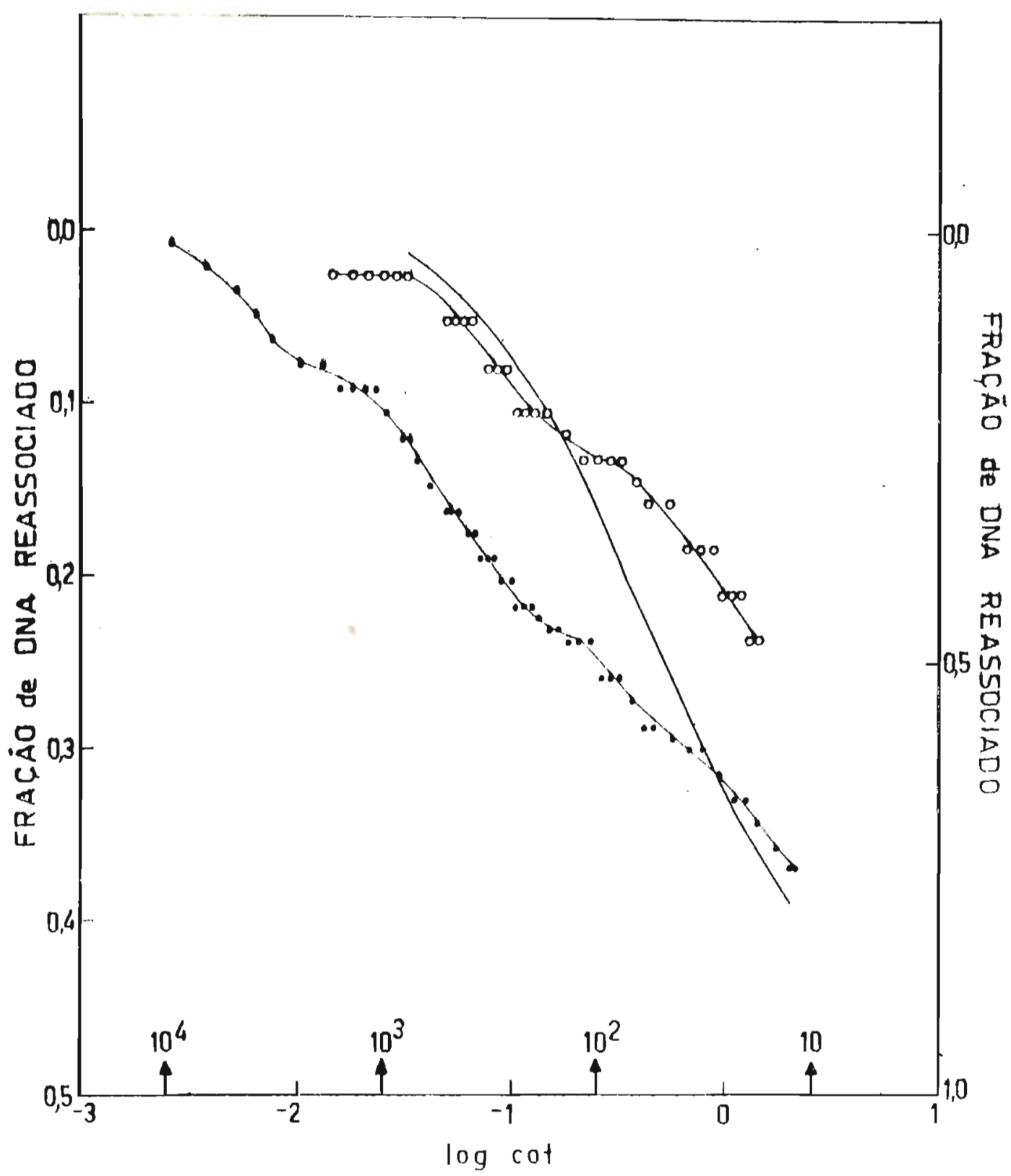

Figura 21 - Renaturação do DNA reiterado de A. castellanii. As condições de incubação e outros detāines sao os mesmos da Figura 20. O perfil de reassociação do DNA de E. coli (linha cheia, escala da direita), ilustra a hëterogeneidade cinética dos outros dois DNAs. O Cot(1/2) para as três secções diștintas da curva de reassociação do componente menor (círculoș cheios) e para as duas retas do DNA mitocondrial (círculos vazios), foi calculado segundo Britten e Kohne (1967), considerando como padrão o $\operatorname{Cot}(1 / 2)$ do DNA de E. colì renaturado nas mesmas condições. Os valores mé dijos obtidos estão resumidos na Tabela 7 . A concentração do DNA mitocondrial e componente menor são respectivamente iguais a 26 e $16 \mu \mathrm{g} / \mathrm{ml}$. 
ver presente, o Cot necessário para 50\% de renaturação da família é reduzido na proporção do grau de repeti ção. Nessas condições, quando se estuda a reassociação de DNA não fracionado, a equação (1) deve ser modjfica da e a frequência de repetição $\left(x_{i}\right)$ de um DNA rapida mente renaturado pode ser calculada a partir da seguinte equação:

$$
\operatorname{Cot}_{1 / 2}=\frac{G}{K x_{i}}
$$

Portantu, para calcular a frequência de repetição, deve-se conhecer o genoma do organismo em estudo.

A equação (2) contém as relações necessárias para a interpretação de medidas de velocidade de reassociação de DNA repetido. Se uma famflia de sequências repetidas está contłada em uma fração a do DNA total, a concentração efetiva muda e a equação (1) não pode ser aplicada. Nesse caso, o $\operatorname{Cot}_{1 / 2}$ para uma determinada familia de DNA reiterado deve ser multiplicada pela fração que ela representa do DNA total ( $\alpha$ ). A complexidade cinética (N) da familia é obtida pela equação:

$$
N=\operatorname{Cot}_{1 / 2} \propto K
$$

Corhecendo-se a e N, pode-se calcular a frequência de repetição do DNA ràpidamente reassocia do:

$$
x_{i}=\frac{\alpha G}{N}
$$

A reação de reassociação do DNA de $\underline{E} \cdot \underline{\text { co- }}$ li (Figura 20) segue uma curva sigmóide com inclinação característica para uma reação homogênea de segunda ordem. A determinação do $\operatorname{Cot}_{1 / 2}$ desse DNA fornece um ponto de calibração adequado, conforme discutido acima. Por outro lado, a heterogeneidade cinética do DNA total, verificada nos gráficos (Figura 16) segundo Wet mur e Davidson (1968), é claramente confirmada pela curva de reassociação ilustrada ria figura 20.

O DNA nuclear arresenta uma cinética de 
rentiuração (Figura 20) característica para sequências que aparecem uma única vez no genoma, apresentando baixa porcentagem de renatiuraço ño intervalo de valores de cot empregador (cerca de 10\%)。A reação de reassocia ção obedece cinética de segunda ordem como pode ser observado pelos dois conjuntos de pontos mostrados na figura 20.

Tabela 7 - Propriedades cinéticas das frações de DNA reiterado de trofozoitos de A. çastellanii

\begin{tabular}{llll}
\hline \multicolumn{1}{c}{ DNA } & $\begin{array}{l}\cot _{1 / 2} \\
\text { observado }\end{array}$ & $\begin{array}{l}\text { Complexidade } \\
\text { cinética } \\
\text { (daltons) }\end{array}$ & $\begin{array}{l}\text { Frequência } \\
\text { de reite- } \\
\text { ração }\end{array}$ \\
\hline componentie & 0,011 & $1,5 \times 10^{6}$ & $2,8 \times 10^{3}$ \\
menor & 0,11 & $2,4 \times 10^{7}$ & $2,8 \times 10^{2}$ \\
& 0,70 & $2,8 \times 10^{8}$ & 45 \\
\hline \multirow{2}{*}{ mitocondrial } & 0,08 & $1,7 \times 10^{7}$ & $3,4 \times 10^{2}$ \\
& 0,60 & $2,4 \times 10^{8}$ & 52 \\
\hline
\end{tabular}

A renaturação ( NaCl $1 \mathrm{M}, 60^{\circ} \mathrm{C}$ ), foi analisada pela queda de absorbância a $260 \mathrm{~nm}$. Os valores médios (3 determina.ções) de complexidade cinética e frequência de reitera ção foram calculados conforme sugerido por Britten e Kohne (1967), por comparação com o cot $1 / 2$ do DNA de E. coli $(0,5)$, com genoma igual a $2,7 \times 10^{9}$ d (Cairns, 1963). $\operatorname{Cot}_{1 / 2}$ é o produto da concentração de DNA (moles de nucleotídios/1), pelo tempo (segundos) necessário para $50 \%$ de reassociação.

A análise da curva de reassociação do componente menor do DNA total (Figur'. 2l), indica considerável hetierogeneidade no grau de repetição das sequênciks de nucleotídios. Fode-se distinguir três frações, com características mostradas na Tabela 7. A complexida 
de cinética e frequência de reitenação de cada fração foram calculadas conforme descrito acima, por comparação com os dados obtidos para o DNA de E. coli, renaturado nas mesmas condições. A renatıração do DNA de E. coli e do componente menor resultam na recuperação de aproximadamente 80 e $50 \%$ da hipocromicidade inicial respectivamente.

o perfil de renaturação do DNA mitocon -drial (Figura 21), mostra a existência de duas frações com complexidade cinética e frequência de reiteração semelhantes às frações do componente menor com velocidade de renaturação "intermediária" e "Ienta" (Tabela 7). A porcentagem média de renaturaçäo do DNA mitocondrial é igual a $40 \%$. 


\section{Isolamento de núcleos}

Vários métodos para extração de núcleos, utilizando meios aquosos de homogenização (ver Métodos), foram testados, sem obtenção de resultados satisfatórios. O procedimento descrito (Métodos), permi tiu o isolamento de núcleos com baixa contaminação por material citoplasmático ou células inteiras (Figura 2). Os núcleos isolados eram, aparentemente, intactos (Figura 3a), mantendo a subestrutura nuclear observada "in vivo" (Figura 3b). O métodos empregado proporcionava resultados reprodutíveis, conforme pode ser julgado pelos valores de desvio padrão obtidos na determinação da composição química de diferentes preparações (Tabela 2).

A demonstração da atividade de RNA polimerase (E.C.2.7.7.6), mostrou que os núcleos, além de estruturalmente intactos, eram fisiológicamente ativos. A reação catalisada pela enzima nuclear era DNA-dependente, conforme demonstrado pelo efeito da adição de actinomicina 1 (Tabela 3 ). Rudick e Weisman (1973a), demonstraram que trofozoitos de $\underline{A}$. castellanii apresentam duas atividades distintas de RNA polimerase-DNA-dependente, fração I e II, sendo que ambas requerem magnésio e manganês para atividade máxima. A fração I era inibida por cicloheximida e a fração II por rifampicina e $\alpha$-amanitina. A inibição da fração II por rifampicina só era obtida com altas concentrações da droga (200 $\mu \mathrm{g} / \mathrm{ml}$ ), ao contrário do que acontece em Amoeba proteus, onde $70 \%$ da sintese de RNA é inibida por concentrações da ordem de $0,1 \mu \mathrm{g} / \mathrm{ml}$ (Tautvydas, 1971). Os resultados aqui descritos (Tabela 3), indicam que núcleos isolados de A. castellanii, apresentam atividade de RNA polimerase-DNA-dependente, que não é inibida por rifampicina na concentração testada $(8 \mu \mathrm{g} / \mathrm{ml})$ 。 
As micrografias eletrônicas (Figura 3), mostram que o processo de isolamento não remove a membrana nuclear extèrna com ribossomos aderidos, que poderiam ser considerados como uma forma de contaminação citoplasmática. A membrana nuclear externa pode ser removida opcionalmente (Blobel e Potter, 1966). Todavia, esse procedimento apresenta vantagens e desvantagens que devem ser consideradas em cada caso específico. Para os objetivos do trabalho aqui descrito, a remoção de traços do retículo endoplasmático das preparações de núcleos foi considerada irrelevante.

A análise de ácidos nucleicos em protozoá rios é dificuldade pelo fato de que poucas espécies são cultiváveis axênicamente (Mandel, 1967). o número de espécies examinadas é pequeno e pouco representativo, especialmente no caso das amebas. Os resultados de composição química de núcleos isolados de A. castellanii (Tabela 2), mostrain que as razões RNA/DNA e proteína/DNA são muito próximas das razões determinadas para núcleos de fígado de rato (Blobel e Potter,1966) e significantemente difierentes das descritas para levedo (Rozijn e Tonino, 1964) e $\underline{A}$. proteus (Tautvydas, 1971). Em A. castellanii, o teor médio de DNA por núcleo, foi avaliado em 10,6 pg (Resultados, item 4) . Esse valor é intermediário entre os valores de 3,5 e $13,6 \mathrm{pg}$, determinados, respectivamente, para Euglena gracilis (Mandel, 1967) e Tetrahymena piriformis (Mandel, 1967), mas, sem dúvida muito menor que os dados para as amebas gigantes, como … proteus (Tautvydas, 1971) e Paramecium aurelia (Isaacks et al., 1973), respectivamente iguais a 34 e 51,2 pg por núcleo. Devese levar em consideração que o conteúdo de DNA por nûcleo obtido pela análise química de núcleos isolados, representa um valor médio (Mirsky e Ris, 1951)。A comparação desses valores médios demonstra o grau de heterogeneidade existente entre microrganismos eucario tos, no que se refere ao conteúdo de DNA por núcleo.

2. Extração de DNA

Vários autores (Kirtikar et al., 1967 ; 
Mandel, 1967; Adam et al., 1969), encontraram dificulda des na extração de DNA de A. castellanii e de outras amebas. O procedimento adotado (Métodos) é uma combinação dos métodos de Kirby (1962) e Adam et al. (1969) descritos, respectivamente, para extração de DNA de ovos de Drosophila e DNA celular total de trofozoitos de $\underline{A}$. castellanii. Ao contrário do métodọ de Adam et al. (1969), o DNA é obtido a partir da fase aquosa da extração com fenol. A metodologia adotada permite a recuperação de grandes quantidades de DNA altamente polimerizado, com peso molecular uniforme, conforme avaliado pelas bandas estreitas obtidas em gradientes de densidade. O DNA obtido era constituído por moléculas nativas que, quando desnaturadas, apresentavam o efeito hipercrômico esperado. Além disso,os valores de peso molecular obtidos em gradientes de sacarose neutros e alcalinos, indicavam ausência significativa de quebras em uma única fita de DNA. O espectro de absorção (Figura 5), apresentava razões de absorbância caracte risticas de DNA puro (Marmur, 1961)。

\section{Caracterização do DNA de trofozoitos}

a) DNA totaI

O DNA celular total de trofozoitos é constituído por dois componentes com densidade de flutuação igual a $1,717 \mathrm{~g} / \mathrm{cm}^{3}$ (componente maior) e $1,692 \mathrm{~g} / \mathrm{cm}^{3}$ (componente menor)。A contribuição de cada componente é respectivamente igual a $84 \%$ e $16 \%$, conforme avaliado a partir do traçado fotoelétrico de DNA total centrifugado em gradientes de CsCl. Um outro satélite menos denso $\left(\rho=1,670 \mathrm{~s} / \mathrm{cm}^{3}\right)$, foi observado em algumas əre parações de DNA total que, quando centrifugadaa em gradientes preparativos de $\mathrm{CsCl}$, apresentavam uma banda muito nítida e opalescente na região de equilúbrio do DNA. Os resultados obtidos quanto à caracterização desse material, indicam que ele seja constituído por glicogênio, já que apresenta teste positivo com o reagente de antrona, sensibilidade à digestão por a-amilase, 
densidade de flutuação semelhante à de glicogênio comer cial (cf. Mandel et al., 1968), précipitação com etanol e natureza não-dializável. Apesar de não apresentar absorção máxima na região ultra-violeta do espectro, o polissacarídeo causa dispersãa de luz suficiente para afetar o espectro de absorção das preparações de DNA (Figura 5). Conclusões semelhantes foram relatadas por outros autores, que verificaram a presença de bandas satélites de glicogênio (Bṛunk e Hanawalt, 1966) ou de outros polissacarídios (cf. Mandel et al., 1968), em gradientes isopicnicos de $\mathrm{CsCl}$. Portanto, componentes desse tipo devem ser analisados com cuidado, para que não possam ser interpretados, errôneamente, como satélites de DNA ricos em AT (Rosenkranz e Carden, III, 1967).

\section{A análise da incorporação de timidina- ${ }^{3} \mathrm{H}$} em material ácido-insolúvel (não descrita neste traba1ho), demonstra que a velocjdade de sintese de DNA diminui muito durante a fase estacionária, conforme verificado anteriormente por Rudick (1971). Fntretanto, a sintese dos dois componentes parece ser afetada diferencialmente. A proporøão do componente menor varia sensivelmente ao longo da curva de crescimento, apresen tando um valor máximo de $16 \%$ do DNA celular total na fase log mediana (Tabela 4). Fenômeno semelhante foi descrito para o DNA mitocondrial de levedo (Moustachi e Williamson, 1966), apesar de existirem controvérsias a esse respeito (Fukuhara, 1969). A porcentagem do componente menor no DNA de cistos ( $7 \%$ ) é semelhante ao valor apresentado por culturas em fim de fase log (6\%), quando se inicia o encistamento em massa das células.A redução da proporção do componente menor no DNA de cisto poderia, pelo menos em parte, ser atribuída à autólise de mitocôndrias, que são incorporadas em autolisossomos durante o encistamento (Bowers e Korn, 1969). A atribuição de um significado funcional à variação da proporção do componente menor é dificultada pela existência de diferentes frações de DNA com densidade média igual a 1,692 $\mathrm{g} / \mathrm{cm}^{3}$. Para efeitı de padronização, todas as experiências aqui descritas, empregam DNA ex- 
traído de células em fase log mediana.

A renatur:ţão do DNA total de trofozoitos apresenta características cinéticas comuns à maioria dos eucariotos estudados (Britten e Kohne, 1967). A curva de reassociação se estende por várias unidades de $l o g$ de cot, sugerindo a existência de vários componentes com diferentes velocidades de reassociação (Figura 20). A distinção entre as diferentes famílias é dificultada pelos valores semelhantes das velocida des de reassociação. Foi possível obter uma aproxima ção através da aplicação da equação (2), (ítem 9, Resultados), para calcular o valor de $\operatorname{Cot}_{1 / 2}$ correspon dente a vários graus de reiteração. Quando uma escala desses valores é marcada no diagrama de $10 \mathrm{~g}$ de cot (Figura 20), obtem-se a delimitação do intervalo de frequências de repetição existentes. O perfil de reassociação obtido nas condições de incubação adotadas (NaCl 1M; $60^{\circ} \mathrm{C}$ ), sugere que $14 \%$ do DNA seja constituido por sequências com frequência média de reiteração igrual a 100. Estudo da cinética de reassociação das fraçôes isoladas fornece uma visão mais detalhada do espectro de sequências repetidas do DNA total.

b) DNA nuclear e componente maior

A comparação entre os resultados obtidos com o componente maior do DNA total e DNA isolado de núcleos de trofozoito (Tabelas 5 e 6), demonstram a identidade entre essas duas espécies de DNA. o alto grau de homogeneidade das sequên cias de bases do DNA nuclear é claramente evidenciado pelo comportamerito em gradientes de CsCl, desnaturação térmica e renaturação. O perfil de fusão é caracteriza do por uma transição abrupta, mostrando um pico gaussiano nas curvas derivadas de desnaturação (Figura 14). Não foram observados satélites em gradientes de CsCl de DNA nuclear nativo ou fragmentado, obtendo-se sempre, apenas uma banda estreita (Figura 9A). O DNA é cinéticamente homogêneo, apresentando uma única reta งm gráficos do tipo sugerido por Wetmur e Davidson 
(1968) (Figura 18). Assim sendo, a proporção de sequências reiteradas no DNA nuclear é muito reduzida e a maior parte das sequências do DNA total com renatura ção rápida deve ter localização citoplasmática. 0 DNA nuclear seria composto principalmente por sequências $\hat{u}-$ nicas que renaturam com um $k_{2}$ igual a 0,106 1.mol ${ }^{-1}$. seg $^{-1}$, que corresponde a uma complexidade cinética de $1,46 \times 10^{11}$ d. A complexidade analítica do DNA nuclear, determinada por análise química de núcleos isolados $(10,6 \mathrm{pg}$ de $\mathrm{DNA} /$ núcleo), apesar de ser um valor médio, aproxima-se da complexidade determinada por métodos cinéticos $\left(1,46 \times 10^{11} d\right)$. A discrepância entre esșes valores poderia indicar a presença de uma pequena quantidade de sequências reiteradas no genoma nuclear, não detectadas pelas técnicas e condições de renaturação em pregadas. Realmente, uma certa porcentagem de sequências com repetição intermediária deve estar presente no DNA nuclear, já que na maioria dos eucariotos estudados, sequências desse tipo parecem estar dispersas ao longo do genoma (Britten e Smith, 1970). Em protozoários, a informação existente é muito escassa, e a ameba repre sentaria um exemplo de eucarioto com proporção muito baixa de sequências reiteradas com localização nuclear.

A proporção de DNA nuclear (86\%) obtida por extrapolação a tempo zero de reação (Wetmur, 1967 ; Wells e Birnstiel, 1969), em gráficos lineares de renaturação (Figura 16), concorda estreitamente com o valor obtido a partir da área das curvas de sedimentação em gradientes analíticos de $\mathrm{CsCl}$ (84\%, Figura 9B).

Os grăficos de renaturação construídos segundo Britten e Kohne (1967), mostram que não há contaminação de DNA nuclear com DNA repetido (Figura 20), confirmando o perfil unimodal observado em gradientes de densidade (Figura 9A).

c) DNA mitocondrial e componente menor

o DNA extraído da fração mitocondrial apresenta densidade de flutuação idêntica à do componente menor do DNA total $\left(1,692 \mathrm{~g} / \mathrm{cm}^{3}\right)$. As mitocôndrias 
não foram tratadas com DNase e o DNA mitocondrial estava consideràvelmente contaminado por DNA nuclear (Figura 10A). Todavia, purificação por centrifugação em gradientes de $\mathrm{CsCl}$, resultou em grande redução da contaminaçao por DNA nuclear (Figura 1OB), representada por moléculas altamente degradadas, conforme mostrado pelo perfil largo e achatado na região de densidade igual a $1,717 \mathrm{~g} / \mathrm{cm}^{3}$. Bohnert (1973) obteve resultados semelhantes, verificando um enriquecimento do componente menor em preparações mitocondriais.

O componente menor do DNA total apresenta uma transiçăo térmica complexa, que sugere uma análise mais detalhada, através da primeira derivada das curvas de fusão (Figura 15A).A transição térmica é excepcionalmente larga e assimétrica. A característica marcante é que essas curvas não apresentam uma distribui cão gaussiana, ao contrário do DNA nuclear. A análise dessas curvas mostra um componente principal com $\mathrm{T}_{\mathrm{m}}$ em torno de $62^{\circ} \mathrm{C}$ e dois componentes de menor importân cia com $\mathrm{T}_{\mathrm{m}}$ de 65 e $75^{\circ} \mathrm{C}$ aproximadamente. A presença de um componente com $\mathrm{T}_{\mathrm{m}}$ semelhante a $75^{\circ} \mathrm{C}$, poderia indicar contaminação por DNA nuclear. Todavia, as prepara ções de componerte menor, quando centrifugadas em gradientes de CsCl, apresentavam um único pico estreito, com densidade igual a $1,692 \mathrm{~g} / \mathrm{cm}^{3}$. Adam e colaboradores (1969) também observaram a presença, no componente menor, de uma espécie de DNA com $T_{m}$ semelhante ao do JNA nuclear.

A curva de desnaturação do componente menor reflete a presença de segmentos de DNA com composições médias de bases bastante diferentes. E provável que a heterogeneidade seja intramolecular e não intermolecu lar, conforme sugerido pela banda única e simétricr ibservada em gradientes de CsCl. Essa interpretação (Bernardi et al., 1970), explica a diferença entre os valores de porcentagem de GC calculados a partir do $T_{m}$ e densidade de flutuação do componente menor do DNA total (Tabela 5)。Não foi feita uma análise exaustiva do perfil de fusão do DNA mitocondrial que, todavia, também apresenta caracteristicas compatíveis com uma com- 
posição heterogênea. A heterogeneidade de composição de bases não é muito comum em organismos eucariotos do tipo selvagem, apesar de ter sido descrita para DNA de cloroplastos de Chlamydomonas (Wells e Sager,1971), DNA de cinetoplastos de Trypanosoma cruzi (Riou e Paoletti, 1967) e DNA mitocondrial de algumas linhagens "petite" de levedo (Bernardi et al., 1970). O arranjo das frações com diferentes razões de bases no DNA mitocondrial, pode ser extrapolado a partir das curvas derivadas de desnaturação e perfil de sedimentação em gradientes de CsCl. Se essas regiões fôssem muito distanciadas, o perfil obtido após centrifugação isopícni ca seria constituído por várias bandas, ou, pelo menos, por uma banda muito alargada. Todavia, obtinhase sempre, uma única banda, caracterizada pela largura esperada segundo o tamanho do DNA utilizado (Vinograd e Hearst, 1962). Os resultados, portanto, sugerem que essas regiões heterogêneas são pequenas e dispersas ao longo do genoma (Wells e Sager, 1971).

Conforme discutido anteriormente (item 9 de Resultados), é possivel avaliar o conteúdo informacional (complexidade de sequência) de um DNA, através de estudos de cinética de renaturação. Os cálculos serão simples sòmente se o DNA em questão apresentar com portamento homogêneo como o DNA nuclear ou o DNA de E. coli, que serviu de padrão nas experiências de reassociação. No caso do componente menor ou DNA de mitocôndrias que se comportaram heterogêneamente, a avaliação da complexidade a partir da determinação das constantes de velocidade é prejudicada pela renaturação precoce das familias de DNA reiterado. Além disso, quando uma família de sequências repetidas é isolada do resto do DNA, ela reassocia mais rapidamente, em virtude do aumento relativo na sua concentração.Nesse caso, o $\operatorname{Cot}_{1 / 2}$ observado nos gráficos de log de Cot, devem ser multiplicados pela fração do DNA original representada pela família de sequencias repetidas, obtendo-se o valor de $\operatorname{Cot}_{1 / 2}$ "puro" (Firtel e Bonner, 1972), ou seja, o Cot $1 / 2$ que seria obtido se o DNA fôsse constituído sòmente pela fração em estudo. As tabelas 6 e 7 resumem os resultados de cinética de 
reassoridção de várias frações de DNA, levando-se em consileração as limitações discutidas. Os resultados obtidos indicam que o DNA reiterado de trofozoitos apresenta três famílias distintas, definidas por frequências médias de reiteração caracteristicas para familias com renaturação "rápida" $\left(3 \times 10^{3}\right)$, "intermediá ria" $\left(3 \times 10^{2}\right)$ e "lenta" (50). O súmero de familias com diferentes velocidades de renaturação encontradas no DNA mitocondrial e componente menor, corroboram a existência de três famílias de sequências reiteradas sugeridas pelo perfil de renaturação do DNA total (Figura 16). Além disso, os valores de frequência de reiteraçăo das familias presentes no DNA mitocondrial e componente menor (Tabela 7), situam-se dentro do intervalo de frequência das sequências reiteradas do DNA total, calculado a partir da complexidade do INNA nuclear (ver escala de valores de Cot $_{1 / 2}$ calculados segundo diferentes graus de reiteração na Figura 20).

A comparação entre os valores de complexi dade cinética e frequência de reiteração (Tabela-7) e $\mathrm{k}_{2}$ aparente (Tabela 6 ), sugere que o DNA mitocondrial contém as famílias com renaturação "intermediária" e "lenta", enquanto que a fração "rápida" deve ter origem citoplasmática extramitocondrial.

Assim, O DNA mitocondrial seria constitú do por um componente principal com velocidade de renaturação compatível com uma complexidade cinética de $2,6 \times 10^{8}$ d (fração "Ienta") e por outro componente com genoma próximo de $2,1 \times 10^{7}$ d (fração "intermediária" ), que representa $35 \%$ do genoma mitocondrial, conforme es timado a partir da hipocromicidade devida a cada fração (Wetmur, 1967). Bohnert (1973), demonstrou que 35\% do DNA mitocondrial era formado por circulos abertos, com um contorno médio de $12,8 \mathrm{um}$, que correspon dem a um PM de $2,77 \times 10^{7} \mathrm{~d}$, valor esse comparável à complexidade cinéticá do componente mais rápido dó DNA mitocondrial $\left(2,1 \times 10^{7}\right.$ d). Portanto, é provável que as moléculas analisadas ao microscópio eletrônico representen as sfquências de bases detectadas nas experiências de rencuração aqui descritas. Adicionalmen - 
te, Bohnert (1973) descreveu a existência de moléculas circulares maiores, moléculas lineares e moléculas colabadas cujo comprimento não pode ser medido, o que impede a comparação com os resultados cinéticos.

A fração intermediária corresponde a $6 \times 10^{9}$ d ( $4 \%$ do genoma da ameba), enquanto que a fração lenta equivale a $1,3 \times 10^{10}$ d $(7,5 \%$ do genoma). A diferença entre a complexidade analítica e a complexida de cinética indicaria, então, que os componentes do DNA mitocondrial estariam presentes, respectivamente, em cerca de 300 e 50 cópias por genoma nuclear.

o DNA mitocondrial de A. castellanii, como acontece em outros microrganismos eucariotos estudados, é constituído por moléculas maiores que o DNA mitocondrial de células de animais vertebrados (Sager, 1972). Os dados obtidos são semelhantes aos valores de tamanho e conteúdo informacional determinados para INA de cloropastos de algas e plantas superiores e DNA mitocondrial de plantas superiores (Sager, 1972). 0 comportamento cinético heterogêneo mostrado pelo $\mathbb{N}$ A mitocondrial de $\underline{A}$. castellanii, foi igualmente verificado em DNAs citoplasmáticos de mitocôndrias (Wells e Birnstiel, 1969) e cloropastos (Wells e Birnstiel, 1969 ; Wells e Sager, 1971), que apresentavam um componente com renaturação rápida, presente em muitas cópias e um componente principal caracterizado por una frequên cia de reiteração menor.

A análise das tabelas 6 e 7 , sugere que - componente menor do DNA total, de localização citoplasmática, contem uma fração de DNA de origem extramitocondrial, presente em aproximadamente $3 \times 10^{3}$ cópias. Esse DNA poderia ser análogo, em células superiores,aos epissomos bacterianos, ou então, demonstraria a existên cia de organismos simbiontes, sugerida anteriormente por Ito et al. (1969). Esses autores postularam que os corpúsculos citoplasmáticos contendo DNA, identificados por autoradiografia, seriam constituídos por vírus defectivos ou epissomos. A complexidade cinética determinada para a fração rápida do DNA da ameba $\left(1,5 \times 10^{6}\right.$ d), exclui a possibilidade de que os simbiontes possam ser 
bactérias ou micoplasmas, concordando com as observações citológicas anteriores (Ito et al., 1969). A natureza extracromosomal desse DNA sugere que uma pequena fração do genoma $(2,5 \%)$, não estaria submetida ao controle de replicação normal, formando múltiplas cópias, cada vez que o genoma da ameba sofresse duplicação. A autonomia genética dessas partículas seria melhor evidenciada, através da determinação do grau de multiplicidade em diferentes estágios de crescimento de culturas de amebas (Chiscon e Kohne, 1970). Qualquer que seja a origem filogenética dessas particulas, elas poderiam representar outro exemplo de um fenômeno comum entre os protozoários; conforme discutido por Soldo e Godoy (1973), que salientam a vantagem seletiva da existência de muitas cópias para a manutenção da continuidade genética em um ambiente intracelular.

Por outro lado, a existência de um DNA citoplasmático extramitocondrial poderia ser relacionada com a extrusão de DNA nuclear para o citoplasma, descrita anteriormente (Bowers e Korn, 1969). A natureza e destino do DN.A liberado são desconhecidos. A caracteriza ção desse DNA poderia fornecer resultados interessantes, já que fenômenos semelhantes foram verificados apenas durante a meiose, envolvendo sempre a amplificação de cistrons ribossômicos (Lima-de-Faria, 1973). Se o DNA citoplasmático, detectado nas experiências de renaturação fôsse de origem nuclear, difícilmente conteria informação para a síntese de rRNA, já que os cistrons ribossômicos, na maiorịa dos eucariotos estudados, têm densidade de flutuação maior que a do DNA nuclear (Birns tiel et al., 1971). Sem dúvida, a atribuição de uma função à fração rápida do DNA total de A. castellanii, requer maior investigação.

\section{Análisse das condições de renaturação}

O grau de precisão de pareamento das sequências de nucleotídios é determinado pelas condições de incubação, ou seja, o tamanho da fração de DNA que reassocia, varia com o "critério" estabelecido durante a 
experiência realizada para estudar esse DNA. Como a reassociação é acelerada em soluções de alta força iônica (Wetmur e Davidson, 1968), adotou-se, rotineiramen te, NaCl $1 \mathrm{M}$ como meio de incubação e temperatura igual a $60^{\circ} \mathrm{C}$. Segundo Rice e Paul (1972), essas condições de incubação evitam a formação de híbridos instáveis e não específicos, apesar de constituírem um critério não muito rígido de renaturação. A adoção de temperatura mais alta ou força iônica mais baixa durante a renaturação, determinariam a formação de moléculas du plas, contendo menor proporção de bases mal pareadas . Todavia, experiências de renaturação empregando DNA dissolvido em SSC, forneceram resultados idênticos aos descritos neste trabalho, possibilitando a conclusão de que as regiões de homologia detectadas eram relativamen te extensas.

As condições de incubação adotadas permitiram evidenciar a heterogeneidade de sequências de bases do DNA mitocondrial de $\underline{A}$. castellanii, evidenciada pelas características do perfil de renaturação e desnaturação térmica. Estudos mais detalhados das curvas de fusão, permitirão estabelecer uma possivel correlação entre as regiões de heterogeneidade local observadas na desnaturação e as famílias com diferentes velocidades de renaturação.

Entretanto, a complexidade cinética das familias de DNA reiterado deve ser interpretada critica mente, já que o "critério" adotado permite a reassociação de sequências semelhantes, mas não idênticas, que poderiam reduzir a velocidade de reassociação (Britten e Bonner, 1971), fornecendo uma medida aumentada do comprimento das sequências que se repetem (Southern, 1970). Deve-se, também, levar em consideração que as moléculas de DNA reassociado poderiam conter regiões não pareadas (Britten e Kohne, 1967), se as sequências repetidas ocorressem em segmentos de DNA muito meno res que os fragmentos de DNA utilizados nas experiên -cias (Tabela 6).

O tamanhio dos fragmentus de DNA e us vam lores relativamente baixos de Cot empregados, não per- 
mitem excluir a existência de uma pequena porcentagem de DNA único no genoma mitocondrial, nem a presença de uma baixa porcentagem de sequências reiteradas no DNA nuclear.

As constantes de segunda ordem obtidas não foram corrigiras quanto ao teor de GC, porque há evidências contraditórias sobre o seu efeito (Wetmur e Davidson, 1968; Gillis et al., 1970). Além disso, no caso do DNA mitocondrial e componente menor, a heteroge neidade de composição de bases impossibilitaria essa correção.

Em resumo, as medidas de frequência e pmoporção de DNA "único" e reiterado de A. castellanij,representam um número mínimo de componentes do genoma,já que a família de reiteração intermediária poderia corter outros componentes; não individualizados através de estudos de cinética de reassociação. 
O trabalho descreve um método para isolamento de núcleos morfologicamente intactos e fisiologi camente ativos, além da caracterização parcial. do DNA de Acanthamoeba castellanii (Iinhagem Neff).

O DNA celular total de trofozoitos contém quatro familias com diferentes velocidades de renaturação. A fração com renatiuração mais lenta (DNA "único"), corresponde ao DNA nuclear ( $86 \%$ do genoma)e apresenta características cinéticas compativeis com uma complexidade de sequência ìghal a $1,46 \times 10^{11}$ daltons. O DNA reiterado ( $14 \%$ do genoma), compreende três familias de sequências de nucleotídios, denominadas "rápida", "intermediária" e "lenta", com complexidade cinética respectivamente igual a $1,5 \times 10^{6} ; 2,1 \times 10^{7} \mathrm{e}$ $2,6 \times 10^{8}$ daltons, presentes em aproximadamente $3 \times 10^{3}$, $3 \times 10^{2}$ e 50 cópias. As famílias de DNA reiterado têm localização predominantementie citoplasmática, sendo que as famílias "intermediárias" e "lenta." fazem par te do genoma mitocordrial. O comportamento cinético he teroêeneo do DNA mitocondrial e sua complexidade assemelham-se aos dados existentes para outros microrganis mos eucariotos. A constatação de uma espécie de DNA extramitocondrial pode ser relacionada com a descrição anterior de corpúsculos citoplasmáticos contendo DNA ou com a extrusão de cromatina para o citoplasma, verificada no início do encistamento.

O DNA de trofozoitos também foi caracteri zado quanto ao padrão de sedimentação em gradientes de densidade, desnaturação térmica e composição de bases. O DNA celular total apresenta dois componentes em gradientes de $\mathrm{CsCl}$, caracterizados por densidade de flu. tuação iguais a $1,717 \mathrm{~g} / \mathrm{cm}^{3}$ (componente maior) e $1,692 \mathrm{~g} / \mathrm{cm}^{3}$ (componente menor). 0 perfil de fusão do DNA mitocondrial sugere heterogeneidade de composição de bases. 
1. Adam, K.M.G. (1959) - "The growth of Acanthamoeba sp. in a chemically defined medium". - J. Gen. Microbiol. 리, 519-529.

2. Adam, K.M.G. (1964) - "A comparative study of Hartmannellid amoebae". - J. Protozool. 11, 423-430.

3. Adam, K.M.G.; Blewett, D.A. e Flamm.W.G. (1969) "The DNA of Acanthamoeba sp.; a method for its characterization". - J. Protozool. 16, 6-12.

4. Alberts, B.M. e Doty, P. (1968) - "Characterization of a naturally occuring cross-linked fraction of DNA. I. Nature of sross-linkage"。-J. Mol. Biol. 32, 379-403.

5. Armstrong, J.A. e Pereira, M.S. (1967) - "Identification of Ryan virus as an amoebo. of the genus Hartmannella". - Brit。 Med. J。1, 212-214。

6. Balsamo, J. (1972) - "Características físicas e funcionais do DNA reiterado de Rhynchosciara americana ". -- Tese de Doutoramento, Instituto de Química, U.S.P., São Paulo。

7. Balsamo, J.; Hierro, J.M. e Lara, F.J.S. ( 1973) "Transcription of repetitive DNA sequences in Rhynchosciara salivary glands" - Cell Different. ?, $119-130$.

8. Band, R.N. (1959) - "Nutritional and related biological. studies on the free-living soil amoeba Hartmanrella rhysodes". - J. Gen. Microbiol. 2l, $80-95$.

9. Band, R.N. (1962) - "The aminoacids requirements of the soil amoeba Hartmannella rhysodes". - J. Protozool. 2, 377-379. 
10. Band, P.N. (1963) - "Extrinsic requirements for encystation by the soil amoeba Hartinfrinella rhysodes". - J. Protozool. 10, 101-10\%.

1l. Band, R.N. e Machemer, C. (1963) - "Environmental intuction of multinucleate Hurtmarnella rhysodes". - Exp. Cell Res. 31, 31-38.

12. Band, R.N. e Mohrlok, S。 (1973 a) - "Observations on induced amitosis in Acanthamoeba" - Exp. Cell Res. 79, 327-337.

13. Band, R.N. e Mohrlok, S. (1973 b) - "The cell cycle and induced amitosis in Acanthamoeba". - J. Protozool。20, 654-657.

14. Band, R.N.; Mohrlok, S. e Rubin, R.W. (1970) - "Se parate induction of amitotic and mitotic division in Acanthamoeba rhysodes". - Nature 227 , 379-381.

15. Bernardi, G.; Faures, M.; Piperno, G. e Slonimski, P.P. (1970) - "Mitochondrial DNA's from respiratcry-sufficient and cytoplasmic respiratorydefficient mutant yeast". - J. Mol. Biol. 48 , $23-42$.

16. Birnstiel, M.L•; Chipchase, M。 e Speirs, J. (1971) "The ribosomal RNA cistrons"。- Progr. Nucleic Acid Res。 Mol. Biol. 11, 351-389.

17. Rirnstiel, M.L॰; Speirs, J.; Purdom, I॰; Jones, K. e Loeniug, E. (1368) - "Properties and compositions of the isolated rihosomal DNA satellite of Xenopus 1aevis:" - Nature 219, 454-463.

18. Bishop, J.O. e Freeman, K.B. (1973) - "DNA sequences neighboring the duck hemoglobin genes". Cold Spring Harbor Symp. Quant. Biol. 38; 7077.26 . 
19. Blobell, G。 e Potter, V.R. (1966) - "Nuclei from rat liver: isolation method that combines purity with high yleld"。 - Science 154, 1662-1665.

20. Blumenfeld, M. e Forrest, H.S. (1972) - "Differential under-replication of satellite DNAs during Drosophila development". - Nature New Biol. 239, $170-172$.

21. Bohnert, H.J. (1973) - "Circular mitochondrial DNA from Acanthamoeba castellanii (Neff strain)".Biochim. Biophys. Acta 324, 199-205.

22. Bolton, E.T. (1966) - "Nucleic acid interactions . A molecular approach to the study of genes and their products". - Ca. Res. 26, 1964-1970.

23. Bonner, T.I. (1973) - "Instantaneous binding fractions of DNA". - Carnegie Inst. Wash. Year Book 72, 204-207.

24. Bowers, B. e Korn, E.D. (1968) - "The fine structure of Acanthamoeba castellanii. I. The trophozoite". - J. Cell Biol. 39, 95-111.

25. Bowers, B. e Korn, E.D. (1969) - "The fine structure of Acanthamoeba castellanii (Neff strain). II. Encystment" - - J。 Cell Biol. 41, 786-805.

26. Bram, S. (1971) - "Secondary structure of DNA depends on base compositior". Nature New Biol. 232, $174-176$.

27. Bray, G.A. (1960) - "A simple, efficient liquid scintilation for counting aqueous solutions in a liquid scintilation counter". - Annal.Biochem. 1, 279-285.

28. Breuer, M.E. e Pavan, C. (1955) - "Behaviour of polytene chromosomes of Rhynchoschiara angelae at different stages of larval development" . Chromosoma ?, 371-386. 
29. Britten, R.J. (1970) - "Observed properties of repeated DNA sequences (april 1969)"。- Carnegie Inst. Wash. Year Book 68, 376-378.

30. Britten, R.J. (1971) - "Sequence complexity, kinetic complexity and genetic complexity". - Carnegie Inst. Wash. Year Book 69, 503-506.

31. Britten, R.J. e Bonner, T. (1971) - "The effect of sequence divergence on the rate of reassociation". - Carnegie Inst。 Wash. Year Book 20, 373374.

32. Britten, R.J. e Davidson, E.H. (1969) - "Gene regulation for higher cells: a theory". - Science 165, 349-357.

33. Britten, R.J. e Kohne, D.E. (1967) - "Nucleotide sequence repetition in $\mathrm{DNA}^{\prime}$. - Carnegie Inst. Wash. Year Book 65, 78-106.

34. Britten, R.J. e Kohne, D.E. (1968) - "Repeated nucleotide sequences". - Carnegie Inst. Wash. Year Book $66,73-88$.

35. Britten, R.J. e Rake, A.V. (1969) - "Search for saltatory replication". - Carnegie Inst. Wash. Year Book o7, 325-327。

36. Britten, RoJ。 e Smith, J。 (1970) - "A bovine genome". - Carnegie Inst。Wash。Year Book 68, 378386.

3\%. Britten, R.J. e Smith, J。F。(1971) - "Cattle, sheep, and satellites". - Carnegie Inst.Wash. Year Book $\underline{69}$, 506-j07。

38. Britten, R。J.; Araham, D.E. e Henerey, M. (1972)"Seaurchin repeated and single-copie DNA". - Car negie Inst. Wash. Year Book 71, 270-273.

39. Brown, D.D。e Gurdon, J.B. (1964) - "Absence of ribosomal RNA synthesis in the anucleolate mutant of Xenopus laevis"。- Proc。Nat. Acad. Sci. Wash。 51, 139-146. 
40. Brown, D.D, e Weler, C,r. (1968) - Gene linkin

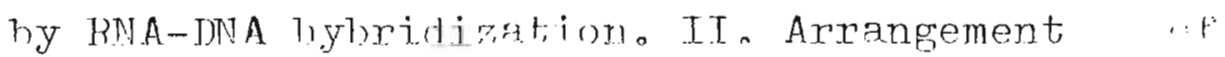
the redumint: frene sequences for 285 and 139 rihosnmat RNA". - T, MOl. Jilol. 34 , 681-69\%.

4.1. Brown, D.D.; Wensink, Poc。 e Jorkan, E. (1972) A comprison of the ribosomal DNA's of Xenopus laevis e Xenopus mulleri: the evolution of tandem fenes". - J. Mol. Bio1. 63, 57-73。

4?. Prunk, C.F. e Hanawalt, P.C. (1966) - "Glycogen satelitite bands in isopynic CsCl gradients", Exp. Cell Res. 42, $406-408$.

43. Burgi, E. e Hershey, A.D. (1963) - "Sedimentation rate as a measure of molecular weight of DNA". Biophys. J. 3, 309-321.

44. Byers, T.J.; Rudick, V.L. e Rurick, M.J. (1.969) "Cel.t. size, macromolecular composition, nuclear number, oxygen consumption and cyst formation du ring two growth phases in unagitated cultures of Acanthamoeba castellanii". - T. Frotozool. 16, $693-699$

45. Callan, H.G. (1967) - "The organjzation of genetic units in chromosomes"。- Jo Cell Sci. 2, 1-7.

46. Cairns, J. (1963) - "The chromosome of E. coli" - Cold Spring; Harbor Symp。Quant. Biol。28, 43$4.6 \%$

47. Carter, R.F。(1968) - "Primary amoebic meningoence phalitis: clinical, pathological and epidemiological features of six cases". - J. Dath. and Bact。 $96,1-25$.

48. Castellani, A. (1930) - "An amoeba growing in culture:s of an yeast"。 - J。Trop。 Med。Hyg。 23 , $160-188$ 。

49. reriotti, Go(1)52) - "A microchemics] determna tion of INA". - Jo Biol. Chem. 198, 297-303. 
50. Cerva, I. e Novak, K. (1968) - "Amoebic meningoencephalitis: sixteen fatalities". - Science, 160, 92.

51. Chambers, J.A. e Thompson, J.E. (1972) - A scanning electron microscopic study of the excystment pro cess of A. castellanii". - Exp. Cell Res. 23, 415-421.

52. Chang, R.S. e Humes, M. (1962) - "The biologic, immunologic and physicochemical characterization of a transmissible agent capable of inducing DNA and thymine degradation in cultured human cells! J. Exp. Med. 115, 937-957.

53. Chang, R.S.; Pan, I. e Rosenau, B.J. (1966) - " On the nature of the lipovirus". - J. Exp. Med. 124, $1153-1166$.

54. Chauveau, J.; Moulé, Y. e Rouiller, C. (1956) "Isolation of pure and unaltered liver nuclei. Morphology and biochemical composition". - Exp . Cell Res. 11, 317-321。

55. Ohiscon, J.A. e Kohne, D.E。 (1970) - "DNA sequences present as multiple copies in E. coli". - Carnegie Inst. Wash. Year Book 68, 388-391.

56. Colli, W. e Oishi, M. (1970) - "A procedure for gene purification: the purification of the riboso mal RNA genes of Bacillus subtilis as DNA-RNA hybrids". - J. Mol. Biol. 51, 657-669.

57. Coll1, W.; Smith, I. e Oishi, M。 (1971) - "Physical linkage between $5 \mathrm{~S}, 16 \mathrm{~S}$ and $23 \mathrm{~S}$ ribosomal RNA genes in Bacillus subtilis". - J. Mol. Biol. 56, 117-127.

58. Corneo, G.; Ginell1, E. e Polli, E. (1970) - "Repea ted sequences in human DNA". - J. Mol. Biol. 48, 319-327.

59. Crick, F.H. (1971) - "General model for the chromosomes of higher organisms". - Nature 234, 25-27. 
60. Crippa, M.; Meza, I. e Dina, D. (1973) - "Sequence arrangement in mRNA: presence of poly (A) and identification of a repetitive fragment at the .; end". - Cold Spring Harbor Symp. Quant. Biol. 38, $933-942$.

61. Crouse, H. e Keyl, H.G. (1968) - "Extra replications in the "DNA pufl's" of Sciara coprophila". - Chromosoma 25, 357-364。

62. Culbertson, C.G.; Smith, J.W. e Minner, J.R. (1958)

- "Acanthamoeba: observations on animal pathogeni city". - Science 127, 1506.

63. Culbertson, C.G.; Smith, J.W.; Cohen, H.K. e Minner, J.R. (1959) - "Experimental infection of mice. and monkeys with Acanthamoeba". - Am. J. Path. 35, 187-193.

64. Davidson, E.H.; Hough, B.R.; Amenson, C.S. e Britten R.J. (1973) - "General interdispersion of repetitive with non-repetitive sequence elements in the DNA of Xenopus"。- T. Mol. Biol. 77, 1-23.

65. di Mauro, E.; Snyder, L。; Marino, P.; Lamberti, A.; Coppo, A. e Tocchini-Valentini, G.P. (1969) "Rifampicin sensitivity of the components of DNAdependent RNA polymerase". - Nature 222, 533-537.

66. Dische, Z. (1955) - "Color rexctions of nucleic acids components". - The Nucleic acids I,285; Ed•; Chargaff, E. e Davidson, J.N.; Academic Press, N.Y.

F.7. Douglas, Mo(1930) - "Notes on the classification of the amoeba found-by Castellani in cultures of a yeast-like fungus". - J. Trop. Med. Hyg. 33, 258-259.

68. Dunnebacke, T.H. e Schuster, F.I. (1971) - "Infec tious agent from a free-living soil amoeba,Naegleria gruberi". - Science 174, 516-518. 
69. Dunnebacke, T.H。 e Williams, R.C. (1967) - "A re interpretation of the nature of "lipovirus" cytopathogenicity". - Proc. Nat. Acad. Sci. Wash. 57, 1363-1370。

70. Eigner, J. e Doty, Po (1965) - "The native, denatured and renatiured states of deoxyribonucleic acid". - J。Mol. Biol。12, 549-580。

71. Firtel, R.A. e Bonner, J。 (1972) - "Characterization of the genome of the cellular sline-mold Dictyostelium discoideum"。 - J.Mol. Biol. 66, 339-361.

72. Firtel, R.A.; Jacobson, A。 e Lodish, H.F. (1972) "Isolation and hybridization kinetics of messenger RNA from the cellular slime-mold Dictyoste lium discoideum". - Nature New Biol. 239, 225 228.

73. Flamm, W.G.; Walker, P.M.B。 e McCallum, M。(1969)"Some properties of the single strands isolated from the DNA of the nuclear satellite of the mouse (Mus musculus)"。- J. Mol. Biol。 40, 423443.

74. Fukuhara, H. (1969) - "Relative proportions of mitochondrial and nuclear DNA in yeast under various conditions of growth". - Eur。J. Biochem . 11, 135-139.

75. Gall, J.G.; Cohen, E.H. e Atherton, D.D. (1973) "The satellite DNAs of Drosophila virilis" • Cold Spring Harbor Symp. Quant. Biol。 38, 417421.

76. Gall, J.C.; Cohen, E.H. e Polan, M॰L。 (1971) - "Re petitive DNA sequences in Drosophila"。-Chromosoma 33, 319-344.

77. Gall. J.G॰; MacGregor, H.C。 e Kidston, M.E.(1969)"Gene amplification in the cocytes of Dytiscid water beetles". - Chromosoma 26, 169-187. 
78. Gambarini, A.G. (1972) - "Estudos sobre os genes responsáveis pela sintese de RNA ribossômico em Rhynchosciara". - Tese de Doutoramento, Insti tuto de Química, U.S.P., São Paulo.

79. Gelderman, A.H•; Rake, A.V. e Britten, R。 J. (1972) - "Transcription of nonrepeated DNA in neonatal and fetal mice". - Proc. Nat. Acad. Sci. Wash. 68, 172-176.

30, Feorgiev, G.P. (1969) - "On the structural organizatjon of operon and the regulation of RNA synthesis in animal cells". - J. Theoret. Biol. ch, $473-490$.

81. Giles, K.W. e Myers, A. (1965) - "An improved diphenylamine method for the estimation of deoxyribonucleic acid". - Nature 206, 93.

82. Goldstein, L。 e Prescott, D.M. (1967) - "Nucleocytoplasmic interactions in the control of nuclear reproduction and other cell cycle stages". - The Control of Nuclear Activity, 3-17; Ed.: Goldstein L., Prentice-Hall, Englewood Cliffs。

83. Graham, D.F.; Neufeld, B.R。 e Britten, R. J. (1973) - "Interspersion of sea-urchin repetitive and nonrepetitive DNA sequences"。 - Carnegie Inst. Wash. Year Book 72, 222-224:

84. Griffiths, A.J. e Hughes, D.E. (1968) - "Starvation and encystment, of a soil amoeba Hartmanella castellanii" - J.FrotozooJ. 15, 673-677。

85. Griffiths, A.J. O Hughes, D.E. (1969) - "The physiology of encystment of Hartmanella castellanii". J.Frotocool. 16, 93-99.

86. Hallberg, R.I. e Erown, D.D. (1969) - "Co-ordinated synthesis of some ribosomal protej.ns and riboso mal RNA in embryos of Xenopus laevis". - J. Mol. Biol. 46, 393-411. 
87. Hennik, W. (.2972) - "Highly repetitive DNA sequences in bhr genome of Drosophila hydei. I. Preferatial localization in the $X$ chromosomal heterochromatin". - J. Mol. Biol. 71, 407-417.

88. Hennig, W. e Walker, P.M.B. (1970) - "Variations in the DNA from two rodent families (Cricetidae: and Muridae.)" - Nature 225, 915-919.

89. Hennig, W.; Hennig, I. e Stein, H. (1970) - "revepeated sequences in the DNA of Drosophila and their localization in giant chromosomes". - Chro mosoma $32,31-63$.

90. Hinegardner, R.T.; Rao, B. e Feldman, D.E. (1964)"The DNA synthetic period during early develop ment of the sea urchin egg". - Exp. Cell Res. 36, 53-61.

91. Hoyer, B.H.; McCarthy, B.J. e Bolton, E.T. (1964)"A molecular approach in the systematics of higher organisms". - Science 144, 959-967.

92. Hymer, W.C. e Kuff', E.L. (1966) - "Isolation of nuclei from mammalian tissues through the use of Triton X-100". - J. Histochem. Cytochem. 12, $359-363$.

93. Ifft, J.B.; Voet, D.H。 e Vinograd, J. (1961 ) it The determination of density distributions and density gradients j.n binary solutions at equilibrium in the nltracentrifuge". - Jo Phys. Chem . 65, $1138-1145$.

94. Isaaks, R。E.; Santos, B,G。 e Musil, G. ( 1973) "Studies on nuclei of Paramecium aurelia. I. Iso lation and purification by continuous or discontinuous sucrose gradient centrifugation and biochemi.cal composition"。- J. Protozool. 20 $4.77-481$.

35. Tlo, S. Cllang, R.S. e Pollard, ToD. (1969) - "Cytoplanic djaluibution of DNA in a strain of hel.mannellid amoeba". - JoProtozool. 16, 638$6+5$ 
96. Jacob, F. e Monod, J. (1963) - "Genetic repression, allosteric inhibition and cellular differentiation". - Cytodifferentintion and Macromolecul.ar. Synthesis, 30-64, Ed. Locke, M.; Academic Press, N. Y.

97. Jahnes, W.G.; Fullmer, H.W. e Li, C.P. (1957) "Free-living amoebae as contaminants on monkey kidney tissue culture". - Eroc. Soc. Exp. Biol. Med. $26,484-488$.

38. James, T.E. e Byers, T.J. (1967) - "The induction of multinuclearity in agitated and in aging cultures of Acanthamoeba sp. Neff". - T. Cell Physi.ol. 20, 53-62.

39. Jensen, T. e Dubes, G.R. (1962) - "Cloning, tritration and differentiation of Acanthamoeba sp. by plating". - J. Parasit. 48, 280-286.

100. John, H.A.; Birnstie」, M.L。 e Jones, K.W. (1969) "RNA-DNA hybridization at the cytological level". Nature 223, 582-587.

101. Jones, K.W. (1970) - "Chromosomal and nuclear loca tion of mouse satellite DNA in didividual cells". Nature 255, 912-915.

1.02. Jones, K.W. e Robertison, F.W. (1970) - "Localiza tion of nucleotide sequences in Drosophila and mouse by "in situ" hybridization of complementary RNA"。 - Chromosoma 31, 331-345.

103, Kedes, L.H. Birnstiel, M.L. (1971) - "Reiteration and clustering of DNA sequences complementary to histore messenger RNA". - Nature New Biol. 2230, 165-169.

104. Kirtikar, M•; Jensen, T. e Meyers, D。 (1967) - "Extraction of DNA from Acanthamoeba castellanii". J.Protozool. 14 (supp1.), 11. 
105. Kit, S. (1961) - "Equilibrium sedimentation in density gradients of DNA preparations from animal tissues"。- J. Mol。Biol. 3, 711-716.

106. Kohne, D.E. (1969) - "Isolation and characterizat ion of bacterial ribosomal RNA cistrons". - Carnegie Inst. Wash. Year Book 67, 310-320.

107. Kohne, D.E. (1971) - "Pattern of DNA acquisition during evolution". - Carnegie Inst. Wash. Year Book 69, 485-488:

108. Kohne, D.E. e Byers, M.J. (1971) - "Studies on the expression, evolution and amplification of DNA sequences". - Carnegie Inst. Wash. Year Book 20, $376-378$.

109. Kohne, D.E.; Chiscon, J.A. e Hoyer, B.H. (1971) "Nucleotide sequence change in nonrepeated DNA during evolution". - Carnegie Inst. Wash. Year Book 69, 488-501.

110. Korn, E.D. e Wright, P.L. (1973) - "Macromolecular composition of an amoeba plasma membrane". - J. Biol. Chem. 248, 439-447.

111. Krishna Murti, C.R。(1971) - "Encystment of amoebae: an example fo single cell differentiation".current Sci. 40, 589-593.

112. Krishna Murti, C.R. (1973) - "Biochemistry of amoebic encystment"。- Biochem. Soc. Transac. I, 1104.

113. Laird, G.D.; McConaughy, B.I. e McCarthy, B.J. (1969) - "Rate of fixation of nucleotide substitutions in evolution". - Nature 224; 149-154:

114. Lima-de-Faria, A. (1973) - "The molecular organization of the chromomeres of Acheta "involved in ribosomal DNA amplification", - Cold Spring, Harbor Symp. Quant. Biol. 38, 559-571. 
115. Liu, C. e Rodina, P. (1966) - "Immunofluorescent studies of human cell cultures and chick embryos inoculated with the ameboid cell "lipovirus complex". - J. Exp. Med. 124, 1167-1178.

116. Loening, U.E.; Jones, K.W. e Birnstiel, M. I. (1969) - "Properties of the ribosomal RNA precursor in Xenopus laevis; comparison to the precursor in manmals and plants". - J. Mol. Biol. 45, 353-366.

117. Lowry, O.H.; Rosebrough, N.J.; Farr, A. L. e Randal1, R.J. (1951) - "Protein measurements with the Folin-Phenol reagent". - J.Biol.Chem. 193, 265-275.

118. Mande1, M. (1967) - "Nucleic acids of Protozoa". Chemical Zoology I; 541-572; Ed.: Kidder, G.W.; Academic Press, N.Y.

119. Mandel, M. e Marmur, J. (1968) - "Use of ultravio let absorbance-temperature profile for determining the guanine plus cytosine content of DNA". Methods in Enzymology XII B, 195-206; Ed, Gros sman, L. e Moldave, K.; Academic Press. N.Y.

120. Mandel, M.; Schildkraut, C.L. e Marmur,J. (1968)"Use of CsCl density gradient for determining the guanine plus cytosine content of DNA". Methods in Enzymology XII B, 184-195; Ed.: Grossman, L. e Moldave, K.; Academic Press, N.Y.

121. Marmur, J. (1961) - "A procedure for the isola tion of DNA from microorganisms". - J. Mol. Biol. 3, 208-2.16。

12\%. Marmur J. e Doty, P. (1961) - "Thermal renatura tion of deoxyribonucleic acid". - J. Mol. Biol. 3, 585-594. 
123. Marmur, J.; Rownd, R. e Schildkraut, C.I. (1963) "Denaturation and renaturation of deoxyribonucleic zcid". - Progr. Nucleic Acid Res. Mol. Biol. 1'. $231-300$.

124. Martin, M.A. e Hoyer, B.H. (1966) - "Thermal stabi lities and species specificities of reannealed animal DNAs". - Biochemistry 5, 2706-2713.

125. Marzzoco, A. e Colli, W. (1974) - "Isolation of nuclei and characterization of nuclear DNA of Acanthamoeba castellanii". - Biochim. Biophys . Acta (aceito para publicação).

126. Mattar, F.E. e Byers; T.J. (1971) - "Morphological changes and the requirements for macromolecular synthesis during excystment of Acanthamoeba castellanii". - J. Cell Biol. 49, 507-519.

127. Melli, M. e Bishop. J.O. (1969) - "Hybridization between rat liver DNA and complementary RNA". J. Mo. Biol. 40, 117-136.

128. Melli, M. e Bishop, J.o. (1970) - "Molecular hybridization between rat liver DNA and complementary RNA". - Biochem. J. 120, 225-235.

129. Melii, M॰; Whitfield, C॰; Rao, K.V.; Richardson,M. e Bishop, J.O. (1971) - "DNA-RNA hybridization in vast DNA excess". - Nature New Biol. 231, 812 .

130. Meneghini, R•; Arnelin, H.A॰; Balsamo, J. e Lara. F.J.S. (1971) - "Indication of gene amplification in Rhyncosciara by RNA-DNA hybridization". - J. Cel1 Biol. 49, 913-916.

131. Mirsky, A.E. e Ris, H. (1951) - "The deoxyribonu cleic acid content of animal cells and its evolutionary significance". - J. Gen. Physiol. 34, $451-462$. 
132. Mockrash, L.C. (1954) - "Analysis of hexose phosphates and sugar mixtures with the anthrone ream gent". - J. Biol. Chem. 208, 55-59.

133. Modak, S. (1973) - comunicação pessoal.

134. Moore, A.E. e Hlinka, J. (1968) - "Hartmannela sp. (Acanthamoeba) as a tissue culture contaminant".J. Nat. Ca. Inst。 40, 569-581.

135. Moustachi, E. e Williamson, D.H. (1966) - "Physiological variations in satellite components of yeast DNA detected by density gradient centrifugation". - Biochem. Biophys. Res. Commun. 23 , 56-61.

136. Mukerjee, H. e Goldfeder, A. (1973) - "Purification and properties of ribonucleic acia polymerase from rat liver mitochondrja". - Biochemistry 1 르, 5096-5101.

137. Mulder, C. e Doty, P. (1968) - "Residual activity of denatured transforming DNA of Haemophilus influenzae: naturall occuring cross-linked DNA". - J. Mol. Biol. 32, 425-435.

138. Munro, H.N. e Fleck, A. (1966) - "The determination of nucleic acids". - Methods of Biochemical Analysis 14, 113-176.

139. Neff, R.J. (1957) - "Purification, axenic cultivation and description of a soil amoeba, Acanthamoeba sp.". - J. Protozool. 4, 1.76-182.

140. Neff, R.J. e Benton, W.F. (1962) - "Localization of cellulose in the cysts of Acanthamoeba sp.'. J. Protozool. 9 (suppl.), 11 .

141. Neff, R.J. e Neft.R。H. (1969) - "The biochemistry of amoebic ercystment;". - Symp. Soc. Exp. Biol. $\underline{23}, 51-81$. 
14.20 Neff, B.J.; Bention, W.F. e Neff, R.H. (1964 a) "The composition of the mature cyst wall of the roil unceba Acanthamoeba sp.". - Jo Cell Biol • 23, $66 \mathrm{~A}$.

1.43.Noff, R..T• Neff, R.H. e Trylor, R.E. (1958) "The mutrition and metabolism of soil amoeba Acallthamoeba sp.". - Physiol. Zool. 31, 73-91.

114. Neft, R.T.; Ray, S.A.; Benton, W.F. e' Wilborn, M. (1964 b) - "Induction of synchronous encystment (differentiation) in Acanthamoeba sp.". - Methods in Cell Physiology I, 55-83; Ed: : Prescott, D.M.; Academic Press, N.Y.

145. Nygaard, O.F.; Gltttes, S. e Rusch, H.P. (1960) "Nucleic acid met,abolism in a slime mold with synchronous mitosis". - Biochim. Biophys. Acta $\underline{38}, 290-305$.

146. Page, F.C. (1967) - "Re-definition of the genus Acanthatmoba with description of three species".J. Frotiozool. 14, 709-724.

147. Pardue, M.I. e Gal.I, J.G. (1969) - "Molecular hybridization of radioactive DNA to the DNA of cytological preparations". - Proc. Nat. Acad. Sci.Wash. 64, 600-604.

148. Pardue, M.I. e Gall, J.G. (1970) - "Chromosomal localization of mouse satellite DNA". - Science $168,1356-1378$.

149. Pardue, M.L。; Brown, D.D. e Birnstiel, M.L॰(1973)"Localization of the genes for 5s ribosomal RNA in Xenopus laevis". - Chromosoma 42, 191-20j.

150. Pardue, M.I॰; Gerbi, S.S.; Eckhardt, R.A. e Gall, J.G. (1970) - "Cytological localization of DNA complementary to ribosomal RNA in polytene chromosomes of Diptera". - Chromosoma 29, 268-290. 
151. Pasternak, J.J.; Thompson, J.E.; SchuJ.tz, T.M॰G.' e

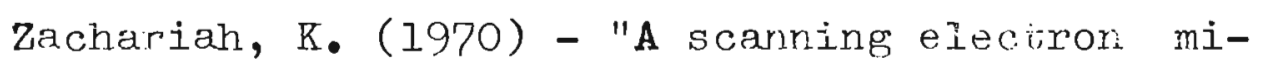
croscopic study of the encystment of Acalthanoeba castellarii". - Exp. Celi Res. 60, 2r30-238.

152. Patras, D. e Andujar, J.J. ( 1966$)$ - "Meningoencepjua Iitis due to Ilartmanne11á (Acarnthamoeba)" - Am. J. Clin. Path. 46, 226-233.

153. Paul, J. (1972) - "General theory of unromosome structure and gene activation in eukaryoties" - Nature 238, 444-446.

154. Paul, J.; Gilmour, R.S.; Affara, N.; Birmie, G. ; Harrison, P.; Hell, A.; Humphries, S.; Windass, . •; e Young, B. (1.973) - "The flobin gene: structure and expression". - Cold anilug ilartor iymp. Quant. Bio1. 38, 885-890.

155. Pavan, C. (1965) - "Nucleic acid metabolism in polytene chromosome and the problem of differentiation". - Brook Haven Symp. on Biol. 18, 222-241.

156. Peacock, W.J.; Brut,Lag, Do; (iolaring, Wo; Appels, R.; Hinton, C.W. e Iindsley, D.L. (1973) - "The organization of highly repeated sequences in Drosophila melanogastier chromosomes". - Cold Spring Harbor Symp. Quant. Biol. 38; 405-415.

157. Potter, J.L. e Weisman, R.A. (1971) - "Differentiation in Acanthamoeba: B-glucan synthesis dיing encystment". - Biochim. Biophys. Acta 237, 65-74.

158. Prescott, D.M. e Krishna Murti, G. (1973) - "Chromo some structure in ciliated protozoans": - Told Spring Harbor Symp. Quant. Biol. 38, 609-618.

159. Raizada, M.K. e Krishna Murti, C.R. (1971) - "Changes in activity of certain enzymes of Hartmannella (Culbertson strain A-1) during encystment". J. Protozool. 18, 115-119. 
160. Raizada, M.K. e Krishna Murti, C.R. (1972 a)

"I'ransformatjon of trophic Hartmannella culbertSorii into viable cysts by cyclic $3^{\prime}, 5^{\prime}$ - adenosine monophosphate". - J. Cell Biol. 52, 743$7 / 18$.

161. Raizada, M.K. e Krishna Murti, C.R, (1972 b) "Synthesis of RNA, protein, ceIlulose and mucopolysaccharide and changes in the chemical composition of Hartmannella culbertsoni during encystment under axenic conditions". - Jo Protozool. 19, 691-695.

162. Ray, D.L. e Hayes, R.E. (1954) - "Hartmannella axtronyxis: a new species of free-living ameba. $\mathrm{Cy}-$ tology and life cycle". - J. Morphol. 25, 159.

163. Rice, N. (1971 a) - "Differences in the DNA of closely related rodents". - Carnegie Inst. Wash. Year Book 70, 366-369.

164. Rice, N. (1971 b) - "Thermal stability of reasso ciated repeated DNA from rodents". - Carnegie Inst. Wash. Year Book 69, 472-479。

165. Rice, N. e Palxl, P. (1972) - "Reassociation of single-copy DNA sequences". - Carnegie Inst. Wash. Year Book 71, 262-264.

166. Ri.ce, N. e Straus, N. (1972) - "Evolution of re peated sequences in the genus Mus". - Carnegie Inst.Wash. Year Book 71, 265-269.

167. Riou, G. e Paoletti, C. (1967) - "Preparation and properties of nuclear and satellite deoxyribonucleic acid of Trypanosoma cruzi". - J. Mol. Biul. 28, $377-382$.

168. Ritossa, F.M. (1972) - "Procedure for magnification of lethal delections of genes for ribosomal RNA".. Nature New Biol. 240, 109-111。 
169. Ritossa, F.M. e Spiegelman, S. (1965) - "Localination of DNA complementary to ribosomal RNA in. the mucleolus organizer region of Drosophila melanogaster". - Proc. Nat. Acar. Sci. Wash. 23, $737-745 \%$

170. Rosenkranz, H.S. e Carden III, G.A. (1967) - "A non-nucleotide polymer found in the DNA of the sand-dollar Echinarachnius parma. I. Isolatj.on".Can. Jo Biochem. 45, 257-?79.

171. Roti Roti, I.W. e Stevens, A.R. (I973) - " DNA synthesis in growth and differentiation of Acanthamoeba castellanii: effects of fluorodeoxyuridine". - Fed. Proc. 32, 616 (abst.).

172. Rozijn, Th. H. e Tonino, G.J.M. (1964) - Study on the yeast nucleus. I. The isolation of nuclei".Biochim. Biophys. Acta 91, 105-112.

173. Rudick, V.J. (1971) - "Relationships between nucleic acid synthetic patterns and encystment in aging unagitated cultures of Acanthamoeba castellanii". - J. Cell Biol. 49, 498-506.

174. Rudick, V.I. e Weisman, R.A. (1973 a) - "DNA-depen dent RNA polymerase from trophozoytes and cystg of Acanthamoeba castellanii".-Biochim. Biophys. Acta 299, 91-102.

175.Rudick, V.t. e Weisman, R.A. (1973 b) - "Effect of cycloheximide on RNA polymerase specific activity and encystment in Acanthamoeba castellanii".Nature $244,220-222$ 。

176. Rudkin, G.T. (1969) - "Non-replicating DNA in Drosophila". - Genetics (Suppl.) 6l, 227-238.

177. Sager, R. (1972) - "Cytoplasmic genes and organelles".; Academic Press, N.Y.

178. Schneider, W.C. e Hogeboom, G.H. (1950) - "Intra cellular distribution of enzymes. V. Further studies on the distribution of cytochrome $C$ in rat liver homogenate". - J. Biol. Chem。183,123128. 


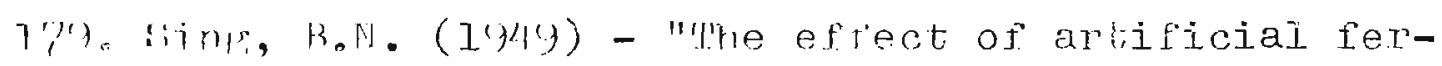
li.lineri; and dung on the numbers of amoebae in Rothamitied soijs". - JoGen. Microbiol. $\underline{3}$, 204t210.

180. Sing, B.N. (1952) - "Nuclear division in nine species of small free-living amoebre and its bearing on the classification of the order Amoebi da". - Phil. Trans. Roy. Soc. Lond. B 236, 405461 .

181. Skinner, D.M. e Kerr, M.S. (1971) - "Characterization of mitochondrial and nuclear satellite deoxyribonucleic acids of five species of crustacea". Biochemistry 10, 1864-1872.

182. Soldo, A.T. e Godoy, G.A. (1973) - " Molecular complexity of Paramecium symbiont Lambda DNA : evidence for the presence of a multiple copy genome". - J. Mol. Biol. 73, 93-108.

183. Sorsa, V.; Green, M.M. e Beerman, W. (1973) - "Cytogenetic fine structure and chromosomal localization of the white gene in Drosophila melanogaster". - Nature New Biol. 245; 34-37.

184. Southern, E.M. (1970) - "Base sequence and evolu tion of guinea-pig $\alpha$-satellite DNA". - Nature 227, 794-798.

185. Southern, E.M. e Roizes, G. (1973) - "The action of a restriction endonuclease on higher organism DNA" - - Cold Spring Harbor Symp. Quant. Biol. 38, $429-433$.

186. Stark, J.R. (1966) - "Some aspects of carbohydrate metabolism in Hartmannella castellanii". - Biocher J. 100, 24-25 P.

187. Steffensen, D.M. e Wimber, D.E。 (1971) - "Localization of tRNA genes in the salivary chromosomes of Drosophila by RNA-DNA hybrikization"。 - Genetics 62, $163-178$. 
188. Stevers, A.R. e Pachler, P.F. (1973 a) - "RNA synthesi and turnover durıng density-inhibited growth and encystment of Acanthamoeba castellaniï". - J. Cell Biol. 57, 525-537.

189. Stevens, A,R. e Pachler, P.F. (1973 b) - "RNA synthesis in density-inhibited growth and differentiation of Acanthamoeba". -. Fed. Proc. 32, 616 (abst.).

190. Stevenson, I. (1967) - "A method for the isolation of macronuclei from Paramecium aurelia ". - J. Protozool. 14, 412-414.

191. Studier, F.W. (1965) - "Sedimentation studies of the size and shape of DNA". - J.Mol. Biol. 11, $373-390$

192. Sutton. W.D. e McCallum, M. (1971) - "Mismatching and reassociation rate of mouse satellite DNA". Nature New Biol. 232 , 83-85.

193. Swift, H. (1973) - "The organization of genetic material in eucaryotes: progress and prospects".Cold Spring Harbor Symp. Quant. Biol. 38, 963979.

194. Tautvydas, K.J. (1971) - "Mass isolated ameba nuclei. I. lsolation procedure and determination of macromolecular composition and RNA polymerase activity". - Exp. Cell. Res. 68, 299-308.

195. Thomas, C.A., Jr. (1970) - "The theory of the master gene". - The Neurosciences: Second study program, p. 973; ed.: Schmitt, F.O.; The Rockefeller Univ. Press, N.Y.

196. Thomas, C.A., Tr.; Hamkalo, B.A.; Misra, D.N. e Lee, C.S. (1970) - "Cyclization of eukariotic deoxyribonucleic acid fragmentis" - T. Mol. Biol. 51, 6cil-652. 
197. Thomas, C.A., Jr॰; Pyeritz, R.E.; Wilson, D. A.; Dancis, B.M.; Lee, C.S.; Bick, M.D.; Huang,H.L•; e Zimm, B.H. (1973) - "Cyclodromes and palindror mes in chromosomes". - Cold Sprine Harbor Symp. Quarıt. Biol. 38, 353-370。

198. Thrower, K.J. e Peacocke, A.R. (1968) - "Kinetic and spectrophotometric studies on the renaturarion of DNA". - Biochem. J. 10y, 543-557.

199. Tomlinson, G. (1967) - "The glyoxylate pathway in Acanthamoeba sp". - J. Protozool. 14, 114-116.

200. Tomlinson, G. e Jones. E.A. (1962) - "Isolation of cellulose from the cyst walls of a soil ameba". - Biochim. Biophys。Acta 63, 194-200.

201. Upadhyay, J.M. (1968) - "Growth and bacteriolytic activity of a soil amoeba Hartmannella glebae".J. Bacteriol. 95, 771-774。

202. Vickerman, K. (1962) - "Patterns of cellular organization in Limax amoebde. An electron microg copic study". - Exp. Cell Res. 26, 497-519.

203. Vinograd, J. e Hearst, J.E. (1962) - "Equilibrium sedimentation of macromolecules and viruses in a density gradient". - Fortschr. Chem. Org. Natstoffe $\underline{20}, 372-420$.

204. Volkonsky, M. (1931) - "Hartmannella castellanii Douglas et classification des Hartmannelles". Arch. Zool. Exp. Gén. 72, 317-339.

205. Walker, P.M.B. (1971) - "Repetitive.DNA in higher organisms". - Progr. Biophys. Mol. Biol. 23, 145-190.

206. Wang, S.S. e Feldman, H.A. (1961) - "Ocurrence of Acanthamoeba in tissue cultures inoculated with human pharyngeal swabs". - Antimicroo. Agents Chemother. I, 50-53. 
207. Waring, M. e Britten, R.J. (1956) - "Nucleotide sequence repetitioll. A rapidly reassociating fract,ion of mouse DNA" - Science 154, 791793.

208. Weisman, R.A. e Moore, M.O. (1.36.) - "Bead uptake as a tool for studying differentiation in Acanthamoeba" - Exp. Cel] Res. 54, 17-22.

209. Weisman, R.A.; Spiegel, R.S. e McCauley, J. G. (1970) - "Differentiation in Acanthamoeba:glycogen levels and glycoger shynthetase activity durjng encystment" - - Biochim. Biophys. Acta 201, 45-53.

210. Wel.1s, R. e Birnstiel, M.L. (1969) - "Kinetic con plexity of chloroplastal DNA and mitochondria]. DNA from higher plants". - Blochem. J. 112,777786.

211. Wells. R. e Sager, R. (1971) - "Denaturation and the renaturation kinetics of chloroplast DNA from Chlamydomonas reinhardi". - J. Mol. Biol. 58, 611-622.

212. Wetmur, J.G. (1967) - "Studies on the kinetics of renaturation of DNA". - Tese de Ph.D。, Calif, Inst. of Technology, California.

213. Wetmur, J.G. e Davidson, N. (1968) - "Kinetics of renaturation of DNA". - T. Mol. Biol. 31, 349-370.

214. Wimber, D.E. e Steffensen. D.M. (1970) - "Localization of 5S RNA genes on Drosophila chromosomes by RNA-DNA hybridization". - Science 170, 639641.

215. Yasminek, W.G. e Yunis, J.J. (1970) - "Localiza tion of mouse satellite DNA in constitutive heterochromatin". - Exp. Cell Res. 59, 69-75. 